POST-EXERCISE MACRONUTRIENT CONSUMPTION \& RESISTANCE TRAINING 


\title{
THE EFFECT OF DIFFERING POST-EXERCISE MACRONUTRIENT CONSUMPTION ON RESISTANCE TRAINING-INDUCED ADAPTATIONS IN NOVICES
}

By
Joseph Hartman, B.Sc. Kin.

\author{
A Thesis Submitted to \\ the School of Graduate Studies \\ in Partial Fulfillment of the Requirements \\ for the Degree \\ Master of Science
}

McMaster University

๔ Copyright by Joseph Hartman, June 2004 
Master of Science (2004)

(Kinesiology)

McMaster University

Hamilton, Ontario

Title: The effect of differing post-exercise macronutrient consumption on resistance training-induced adaptations in novices

Author: Joseph Hartman, B.Sc. Kin. (Laurentian University)

Supervisor: Dr. Stuart Phillips

Number of Pages: xi, 112 


\section{ABSTRACT}

Resistance exercise training results in skeletal muscle hypertrophy due to accumulated periods of protein accretion, the magnitude of which may be influenced by post-exercise feeding. One study suggests that hypertrophy is maximized by immediate provision of protein (26); how the type of protein ingested in this period affects protein accretion is not known. PURPOSE: To investigate the effect of consuming different post-exercise beverages - milk (MLK), an isonitrogenous and isoenergetic soy drink (PEC), or an isoenergetic control (CON) - on body mass, fat-bone free mass (FBFM), muscle fibre area, and strength during a 12-week progressive whole body resistance training program, in untrained men. METHODS: 34 men were randomized to postexercise consumption of $\operatorname{MLK}(n=12$; fat free), $\operatorname{PEC~(~} n=11$; soy) or $\operatorname{CON}(n=11$; maltodextrin) using single-blinded allocation, with characteristics- $22.5 \pm 0.6 \mathrm{yr}, 25.6 \pm$ $0.7 \mathrm{~kg} / \mathrm{m}^{2}$. Participants trained $5 \mathrm{~d} / \mathrm{wk}$ using a whole body split resistance training program and consumed $500 \mathrm{ml}$ of their assigned drink immediately and $1 \mathrm{~h}$ post-exercise following every training bout. RESULTS: Total body mass increased following training $(\mathrm{P}<0.01)$ but there were no differences between groups $(\mathrm{MLK}=3.2 \pm 0.8 \mathrm{~kg}, \mathrm{PEC}=2.9 \pm$ $1.4 \mathrm{~kg}, \mathrm{CON}=2.0 \pm 0.8 \mathrm{~kg})$. Similarly, FBFM also increased post-training $(\mathrm{P}<0.01)$, but was not different between groups $(\mathrm{MLK}=3.3 \pm 0.6 \mathrm{~kg}, \mathrm{PEC}=2.7 \pm 0.6 \mathrm{~kg}, \mathrm{CON}=2.2 \pm$ $0.6 \mathrm{~kg})$. Muscle type II fibre area increased post-training $(\mathrm{P}<0.05)$ but was not different between groups $\left(\mathrm{MLK}=1004 \pm 249 \mu \mathrm{m}^{2}, \mathrm{PEC}=650 \pm 192 \mu \mathrm{m}^{2}, \mathrm{CON}=565 \pm 120\right.$ $\left.\mu \mathrm{m}^{2}\right)$. Training resulted in increases in $1 \mathrm{RM}$ strength for 13 different exercises $(\mathrm{P}<0.01)$ 
with no difference between groups (range $=29-101 \%$ ). CONCLUSION: Immediate post-exercise provision of either milk (MLK), or an isonitrogenous / isoenergetic soy drink (PEC), as well as an isoenergetic carbohydrate beverage (CON), resulted in similar increases in body mass, FBFM, type II muscle fibre area, and strength. This study demonstrates that intact dietary proteins from milk and soy are effective for promoting skeletal muscle hypertrophy. Moreover, when given equivalent energy immediately postexercise, proteins consumed as part of a normal diet, outside of the immediate postexercise period are sufficient for hypertrophic and strength gains. Finally, post-exercise consumption of protein is no more effective than carbohydrate for promoting skeletal muscle hypertrophy when adequate protein is consumed within a regular diet. 


\section{Contribution}

This study was a joint effort with the contribution of several individuals in order to ensure its overall success. As well, portions of the data collected for this study were used by other students as a Master's thesis, as well as an undergraduate thesis. My personal contribution to the study, and data analysis are as follows. I acted as the study coordinator and for 3 months prior to the beginning of the study I organized the study and recruited all 36 subjects on my own. I performed all the DEXA scans on my own and assisted in all muscle biopsy procedures. I was present for all blood sampling procedures and took over half of the samples personally, and processed all of the samples for further analysis. I oversaw all 1RM tests throughout the study and performed many tests personally. As the coordinator I oversaw a group of 12 trainers who performed the majority of the training.

Following the data collection period I analyzed all the DEXA and 1RM data personally. I also performed the glucose and lactate sample analysis. Diet record data was entered by myself and two other individuals working for the study. Muscle fibre slicing in preparation for ATPase staining was performed jointly by myself and Jason Tang, and I performed all ATPase staining of the samples. Analysis of the muscle fiber area was performed primarily by myself, and Jason Tang analyzed some samples. Insulin analysis was done in coordination with Dan Moore who also had samples to analyze from his own independent study, we were both present for all procedures, and analyzed our own samples personally. I personally feel that although I had lots of help with this project, the amount of work that I performed throughout this study was greater than many Master's projects done independently. 


\section{Acknowledgements}

I would never have gotten through this thesis without the help and encouragement of the many great people around me. I would like to thank my family (Mom, Dad, Catherine, David and Marie) and friends who have always encouraged me to pursue my passions, and have been there to point me in the right direction when I had questioned some of my decisions.

I would like to acknowledge my committee members. To Dr. Martin Gibala, Dr. Mark Tarnopolsky and Dr. Digby Sale, thank you for your motivation, advice and guidance, I consider myself privileged to have had the chance to work with such great minds.

I can't even begin to express my gratitude toward my supervisor Dr. Stuart Phillips, who took a chance on some kid he hadn't even met and gave me the opportunity to work with him. You are an excellent supervisor, and a great friend, thank you for all that you've done for me over the past two years, not only are you a great role model but also a great person.

To all the people who helped with the study, Jason Tang, Mark Rakobowchuk, Jenn Perco, Randa Lawrence, Amy Fullerton, Carol Correia, Adam Beveridge, Sarah Wilkinson. There is no way that I could have gotten through those 12 weeks without all your help.

Finally, to all the great friends that I've made over the past two years, you are the life of this program and kept me going during the days when I thought that if I saw another muscle fibre I might snap. Kirsten Burgomaster, Dan Moore, Mark R, Jason T, Todd Prior, Jenn P, Kristen Dawson, and Krista Howarth thanks for being such great friends. 


\section{TABLE OF CONTENTS}

Title Page

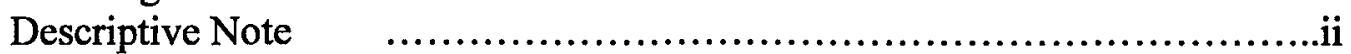

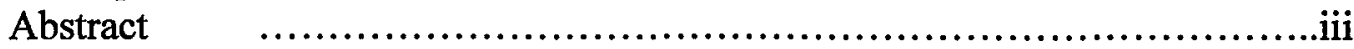

Contribution

Acknowledgements $\quad$...............................................................................................

List of Appendices

List of Figures $\quad$.

List of Tables $\quad$...........................................................

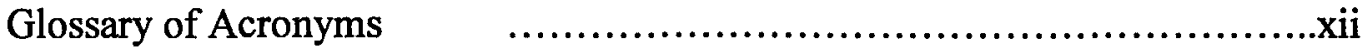

Chapter I: Literature Review

1.1 Introduction $\quad$.................................................

1.2 Resistance Exercise and Protein Turnover $\quad$....................p.2

1.2.1 Protein Breakdown Following Resistance Exercise $\quad$...p.p.2

1.2.2 Protein Synthesis Following Resistance Exercise ...p.4

1.2.2.1 Time Course of Protein Synthesis ............p. 4

1.2.3 Protein Balance Following Resistance Training …p.5

1.3 Amino Acid Supplementation $\quad$.................................. 8

1.3.1 Amino Acid Supplementation at Rest ...................p.8

1.3.2 Amino Acid Supplementation and Resistance Exercise ...p.9

1.3.3 Timing of Amino Acid Supplementation Following Resistance Exercise $\quad$...................................13

1.4 Mechanisms $\quad$................................................ 16

1.4.1 Influence of Insulin $\quad$.................................p. 16

1.4.2 Availability of Amino Acids $\quad$...........................p. 18

1.4.3 Influence of Protein Source $\quad$...........................p. 18

1.4.4 Carbohydrate Ingestion ................................. 22

1.5 Statement of Purpose $\quad$........................................ 25

Chapter II: The effect of differing post-exercise macronutrient consumption on resistance training-induced adaptations in novices

2.1 Introduction

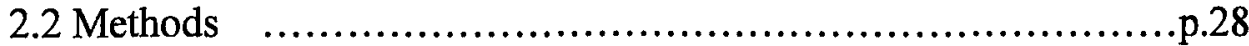

2.2.1 Experimental Protocol $\ldots \ldots \ldots \ldots \ldots \ldots \ldots \ldots \ldots \ldots \ldots \ldots \ldots . . .28$

2.2.2 Pre, Mid, and Post Testing $\quad$........................... 30 
2.2.3 Exercise Training $\quad$................................... 32

2.2.4 Hitochemical Analysis .................................p.33

2.2.5 Insulin Analysis $\quad$................................. 35

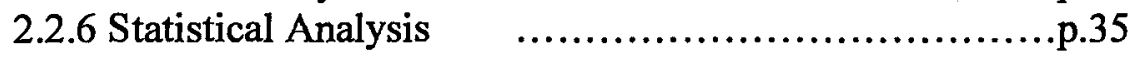

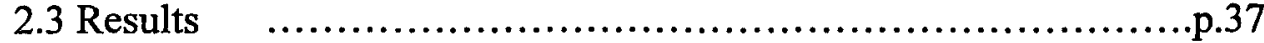

2.3.1 Anthropometry $\quad$.................................... 37

2.3.2 Dietary Analysis $\quad$....................................37

2.3.3 Histochemistry $\quad$..................................p.40

2.3.4 Strength Measurements ................................p.43

2.3.5 Glucose and Insulin Response to Exercise and Supplement Consumption ........................................... 46

2.3.6 Correlational Analyses $\ldots \ldots \ldots \ldots \ldots \ldots \ldots \ldots \ldots \ldots \ldots \ldots . . p .48$

2.4 Discussion $\quad$.................................................. 49

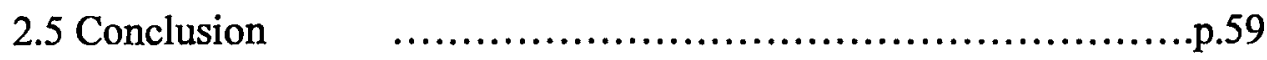

References $\quad$............................................... 61 


\section{LIST OF APPENDICES}

APPENDIX 1: DIET RECORD DATA, and ANOVA TABLES $\quad$..............p.70 APPENDIX 2: SUBJECT CHARACTERISTICS $\quad$...........................p.77

APPENDIX 3: BODY COMPOSITION RAW DATA DETERMINED $\quad$......p.80 BY DXA, AND ANOVA TABLES

APPENDIX 4: FIBRE AREA RAW DATA, AND ANOVA TABLES .....p.85

APPENDIX 5: \% FIBRE DISTRIBUTION RAW DATA AND ANOVA ......p.89 TABLES

APPENDIX 6: BLOOD GLUCOSE CONCENTRATIONS RAW DATA AND ANOVA TABLES ..p.93

APPENDIX 7: BLOOD INSULIN CONCENTRATIONS RAW DATA AND ANOVA TABLES .p.96

APPENDIX 8: CORRELATIONS .p.99

APPENDIX 9: DRINK COMPOSITIONS .p.106 APPENDIX 10: AA COMPOSTION OF MILK AND SOY PROTEINS .......p.108 APPENDIX 11: ATPase HISTOCHEMISTRY PROTOCOL .p. 110 


\section{LIST OF FIGURES}

Figure 1. Hypothetical response of muscle protein synthesis to repeated workouts during a resistance exercise training program (....p.5

Figure 2. Muscle PS, PB, NPB after exercise during consumption of solutions of placebo (PLA), $40 \mathrm{~g}$ of mixed amino acids (MAA), and $40 \mathrm{~g}$ of essential amino acids (EAA) p.10

Figure 3. Phenylalanine net balance across leg after resistance exercise (.....p. 12

Figure 4. FBFM pre and post training (DXA) .p.40

Figure 5. Type 1 fibre area pre and post training ..p.42

Figure 6. Type II fibre area pre and post training .p.42

Figure 7. Blood glucose response to leg exercise and supplement consumption ..p.47

Figure 8. Blood insulin response to leg exercise and supplement consumption ..p.48 


\section{LIST OF TABLES}

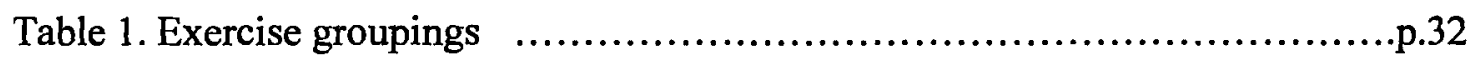

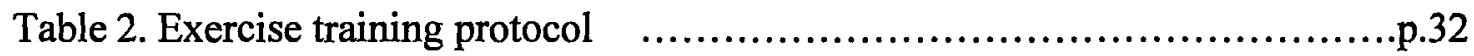

Table 3. Body composition determined by DXA $\quad$.............................p.38

Table 4. Diet analysis before training and at 6 and 12 weeks of training $\quad$.........p.39

Table 5. Fibre area pre and post training $\quad$....................................p.41

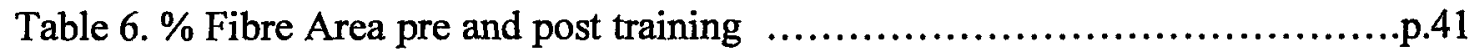

Table 7. 1RM (pushing exercises ) strength pre and post training $\quad$................p.44

Table 8. 1RM (pulling exercises ) strength pre and post training $\quad$.................p.45

Table 9. 1RM (leg exercises ) strength pre and post training ....................... 45 


\section{GLOSSARY OF ACRONYMS}

$1 \mathrm{RM}-1$ repetition maximum

AA - amino acid

BCAA - branched chain amino acid

BMC - bone mineral content

$\mathrm{CON}$ - isoenergetic control

$\mathrm{CHO}$ - carbohydrate

DXA - dual energy $x$-ray absorptiometry

EAA - essential amino acids

EAC - essential amino acid carbohydrate

eIF2B - eukaryotic initiation factor 2B

FBFM - fat and bone free mass

FFM - fat free mass

FSR - fractional synthesis rate

MAA - mixed amino acids

MHC - myosin heavy chain

MLK - fat free milk

$\mathrm{NPB}$ - net protein balance

$\mathrm{N}$ - nitrogen

$\mathrm{PB}$ - protein breakdown

$\mathrm{PEC}$ - isonitrogenous / isoenergetic control

PS - protein synthesis

RIA - radioimmunoassay

TBM - total body mass 


\subsection{INTRODUCTION}

Skeletal muscle constitutes the largest mass of protein in the human body. It is well known that resistance exercise, when performed regularly and at sufficient intensity, increases skeletal muscle protein mass. Many acute studies have focussed on the combined effects of resistance exercise and amino acid supplementation on muscle protein anabolism. Resistance exercise alone provides a potent stimulus for protein synthesis and, over time, muscle hypertrophy $(49,59)$. Recent studies have found that consumption of amino acids post-exercise stimulates net muscle protein synthesis, primarily due to an increase in muscle protein synthesis rather than a decrease in breakdown $(67,84)$. Also, the provision of glucose alone during the post-exercise period, while it promotes a more positive protein balance, does not result in a net positive protein balance (12). Thus, protein is an important component to include in a post-exercise meal in order to promote muscle protein accretion.

Protein source is an important determinant of postprandial protein metabolism in response to feeding $(3,21,22)$. So called "slow" and "fast" proteins demonstrate differing protein kinetics $(3,21)$. Slow proteins such as casein have a greater postprandial retention rate compared to a fast protein such as whey $(3,21)$. Milk (at $20 \%$ whey and $80 \%$ casein) and soy proteins have been classified as slow and fast protein sources respectively $(14,28)$, and their ability to stimulate muscle protein synthesis in different tissue compartments varies. Soy protein promotes greater protein synthesis efficiency (defined as the fraction of intracellular amino acids flux of appearance that is 
incorporated into protein (28)) in the splanchnic bed, whereas milk promotes greater protein synthesis efficiency within the peripheral tissues, most likely muscle (28). This implies that milk might be superior for promotion of skeletal muscle protein accretion than soy when consumed post-exercise, since milk proteins would provide a greater stimulus for muscle protein synthesis.

This review will focus on in vivo studies performed on human subjects. The influence of amino acid consumption will be examined in detail, along with possible mechanisms underlying the responses observed following resistance exercise. The influence of protein composition and its source on muscle protein accretion will be discussed, along with adaptations to resistance training.

\subsection{RESISTANCE EXERCISE AND PROTEIN TURNOVER}

\subsubsection{PROTEIN BREAKDOWN FOLLOWING RESISTANCE EXERCISE}

Resistance exercise has a profound effect on protein metabolism both acutely and chronically. Controversy exists as to whether protein breakdown is increased during exercise; however, evidence clearly demonstrates that skeletal muscle proteolysis is elevated post-exercise in the fasted state $(7,59)$. The response of muscle protein breakdown following exercise has not been extensively studied and differing results have been found. Some studies have reported increases in rates of muscle protein breakdown post-exercise $(24,25,62)$, whereas others have reported no change $(63,64)$ or decreased $(55,66)$ protein breakdown in response to exercise. These studies have all examined 
protein breakdown based on the rate of excretion of 3-methylhistidine in urine, an amino acid that is post-transcriptionally modified and exists only in actin and myosin and is excreted after protein breakdown. Some of the variability in the literature as to the response of muscle protein breakdown to resistance exercise are likely due to the use of 3-methylhistidine as a marker of skeletal muscle breakdown.

Measurements of protein breakdown based on tracer dilution techniques are likely to be more robust than 3-methylhistidine excretion due to the fact that 3-methilhistidine is simply a marker of protein breakdown whereas tracer dilution techniques are a more direct measure. Biolo and colleagues $(4,6,9)$ have utilized a three compartment model using values of labelling and concentrations of amino acids in arterial and venous blood, as well as the labelling of tissue-free tracee to quantify muscle protein breakdown after a bout of resistance exercise $(4,6,9)$. They observed that muscle protein breakdown was increased following heavy leg resistance exercise, but to a smaller extent than muscle protein synthesis, resulting in a more positive, and yet negative, net balance. A second approach to examine post-exercise proteolysis used a precursor product method that determined the decay in enrichment of labelled phenylalanine in the venous blood and the muscle intracellular free amino acid pool (102). When this methodology was applied following intense knee extension exercise, it was observed that the rate of muscle protein breakdown was increased by $\sim 50 \%$ in untrained human subjects $(59,60)$. Hence based on the results of tracer studies there is general agreement that protein breakdown is increased following resistance exercise. 


\subsubsection{PROTEIN SYNTHESIS FOLLOWING RESISTANCE EXERCISE}

An acute bout of resistance exercise has a dramatic stimulating effect on the rate of muscle protein synthesis $(49,59)$. Conversely, there are some reports of a lack of response in muscle protein synthesis following resistance exercise $(70,86)$. However, the subjects examined in these latter studies $(70,86)$ were highly trained, and their response might be expected as the result of a biological adaptation to a stressor such as exercise (see below). From the results of various studies $(7,8,9,49,59)$ it can be stated with good confidence, that when the stimulus is sufficient, that intense resistive contractile activity stimulates muscle protein synthesis. The exercise-induced increase in muscle protein synthesis in the fasted state results in a less negative net protein balance following resistance exercise, but the overall net balance remains negative (59). It is not until the ingestion of amino acids post-exercise that net protein balance becomes positive (8). This relationship will be discussed further.

\subsubsection{TIME COURSE OF PROTEIN SYNTHESIS}

Resistance exercise can stimulate muscle protein synthesis for up to $48 \mathrm{~h}$ following an acute bout $(49,59)$. MacDougall and colleagues (49) measured protein synthesis in humans for 36 hours following a single bout of resistance exercise and found that muscle protein synthetic rates were elevated by $50 \% 4 \mathrm{~h}$ post-exercise, and by $109 \%$ at $24 \mathrm{~h}$ post-exercise. At the $36 \mathrm{~h}$ time point protein synthetic rates had returned to baseline. Phillips and colleagues (59) observed that a bout of heavy resistance exercise 
increased mixed muscle fractional synthesis rates by $112 \%$ at $3-\mathrm{h}, 65 \%$ at $24 \mathrm{~h}$, and $34 \%$ at $48 \mathrm{~h}$ post-exercise. Phillips et al (59) hypothesized that the discrepancy between the two studies at the $48 \mathrm{~h}$ time point may be due to the training status of the subjects, since the time course of muscle fractional synthesis rates after exercise may be different in trained vs. untrained subjects. This hypothesis is reinforced by findings that in trained subjects there was an attenuated rate of protein synthesis following a bout of resistance exercise when compared to the untrained state (61), which in theory would result in a blunted protein synthetic response in the trained state.

\subsubsection{PROTEIN BALANCE FOLLOWING RESISTANCE TRAINING}

Resistance exercise training is well known to induce hypertrophy of the trained muscles $(40,47)$. The effects of resistance exercise training on human muscle protein

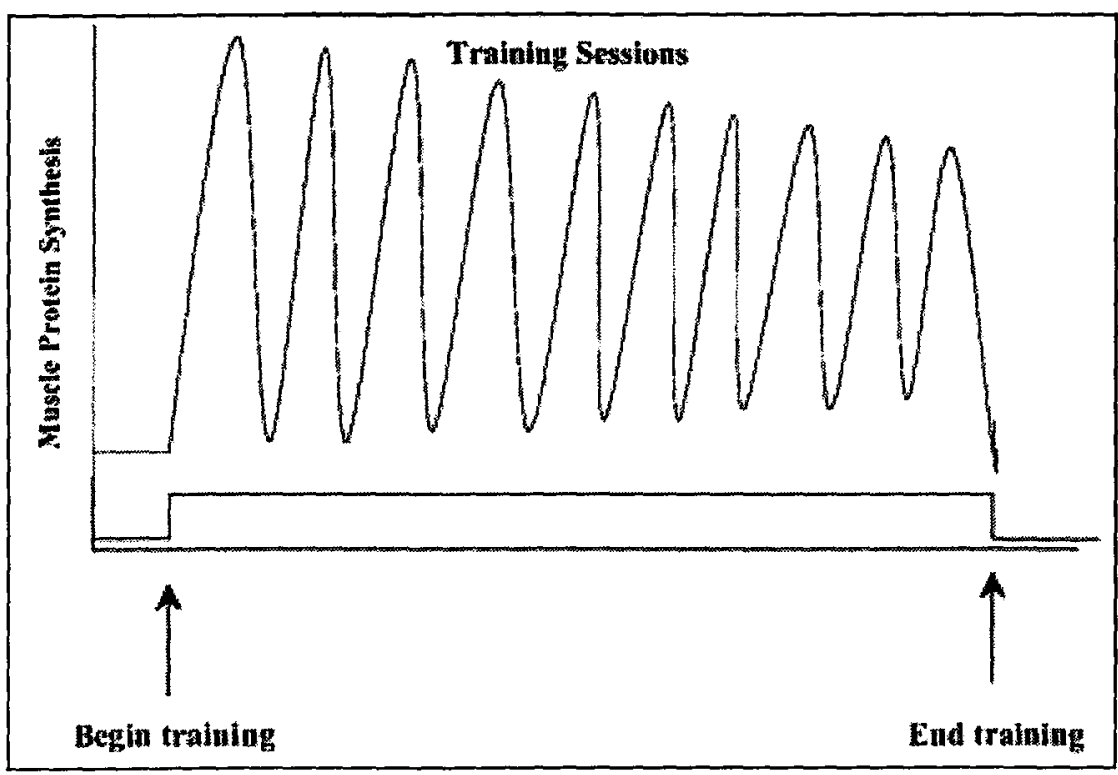

Figure 1. Hypothetical response of muscle protein synthesis to repeated workouts during a resistance exercise training program. Rennie and Tipton (69). 
synthesis and breakdown have not been extensively studied. Intuitively, muscle hypertrophy resulting from resistance exercise is caused by an increase in muscle protein synthesis that exceeds protein breakdown in the resting recovering muscle. However, an important question is the extent to which the basal rate of resting protein turnover is elevated as a result of training. In a recent review Rennie and Tipton (69) hypothesized that assuming muscle protein synthesis responds to a repeated stimulus of a constant size (e.g. applied in a square wave pattern) as do other physiological systems (e.g. maximal oxygen consumption capacity and aerobic power), then it is likely that a series of training stimuli will result in a series of responses each of which is progressively reduced (see Figure 1). Thus, theoretically, an increased stimulus should be necessary post-training to initiate a response similar to that observed before training.

The results of a cross-sectional analysis by Phillips and colleagues (60) indicate that resistance trained subjects display an attenuated response to an acute bout of resistance exercise compared with sedentary, untrained controls. The response of muscle protein turnover was compared between these two groups, both at rest and after intense resistance exercise. Protein turnover was greater in the exercised leg than in the control leg. Most importantly, the increase in both muscle protein synthesis and breakdown in the trained subjects was decreased by $\sim 50 \%$ compared with that in the untrained subjects. There were no significant differences between trained and sedentary groups in the resting values of protein synthesis and breakdown, although trained athletes displayed slightly higher fractional synthetic rates at rest (60). 
A more recent study by Phillips and colleagues (61) examined resistance training induced adaptations in skeletal muscle protein turnover in the fed state. Conclusive evidence for the attenuation of the acute response of muscle protein turnover in response to a single bout of resistance exercise was observed. In this longitudinal study young, untrained men completed 8 weeks of resistance training. It was found that resistance training attenuated the acute exercise-induced rise in fractional synthesis rate by $\sim 20 \%$ (61). The results from this study clearly demonstrate that resistance training leads to an attenuation of the acute response of muscle protein turnover in response to a single bout of resistance exercise, which reinforces the hypothesis of Rennie and Tipton (69). Further evidence of a down regulatory adaptation to resistance exercise has been observed in rats. Farrell and colleagues (27) reported that post-exercise muscle protein synthesis was reduced in rats that had been resistance trained for 8 weeks compared with untrained rats.

Most studies indicate that training-induced muscle growth is a result of an accumulated set of anabolic responses to each individual exercise training session, rather than a change in basal net protein balance. However, there is some evidence that presents conflicting results. It has been reported that resistance exercise training, for as little as 2 weeks, increases resting muscle protein synthesis in both young and elderly humans (96, 98). The findings in young subjects may have been confounded by the fact that the initial pre-training measures were made at rest, and the post-training measures were made within $24 \mathrm{~h}$ after the last bout of resistance exercise (96). As mentioned previously protein synthesis rates can be elevated for up to $48 \mathrm{~h}$ following a bout of resistance 
exercise (59). Therefore, it would be difficult to differentiate the response of muscle to the chronic effect of training from the response to the last acute exercise bout. In other words, any chronic training-induced increases in basal muscle protein synthesis are likely simply an artefact from the last workout bout, and not due to the chronic effect of training. In the elderly, it may simply be that training may have normalized an age or inactivity-related reduction in the basal rate of protein turnover. However, results from Phillips and colleagues (61) contradict these findings. They observed that following training, at rest 72-h after the last training bout, muscle protein fractional synthesis and breakdown rates were greater in the trained state. The increase in protein synthesis was greater than the increase in breakdown thus creating an elevated net protein synthesis rate at rest. This adds conclusive evidence demonstrating an increased basal rate of protein turnover following 8 weeks of resistance training in young males. Obviously, more research is needed in order to solidify these findings, but evidence does suggest that basal protein turnover is upregulated following resistance training.

\subsection{AMINO ACID SUPPLEMENTATION}

\subsubsection{AMINO ACID SUPPLEMENTATION AT REST}

It is now generally accepted that amino acid availability is an independent regulator of muscle protein turnover (1). It has been observed that increased amino acid availability stimulates muscle protein synthesis $(1,8)$. Biolo and colleagues $(8)$ observed that hyperaminoacidemia resulting from intravenous infusion of amino acids, increased 
protein synthesis at rest. A recent study examined the latency and duration of stimulation of human muscle protein synthesis during continuous infusion of amino acids and found that muscle protein synthesis responds rapidly to increased availability of amino acids but then returns to basal concentrations, despite continued amino acid availability (2). Bohé and colleagues (2) found that a square-wave increase in the availability of plasma amino acids took between 30 min and $1-\mathrm{h}$ to have any measurable effect on muscle protein synthesis. From the $1 \mathrm{~h}$ mark muscle protein synthesis was markedly stimulated by $\sim 2.8$ fold for a period of $1.5 \mathrm{~h}$ before falling to a value not significantly different from the basal value for the subsequent $4 \mathrm{~h}(2)$.

The results from Bohé et al (2) suggest that as previously observed, overfeeding protein does not increase the size of lean body mass, and excess amino acids are simply oxidized $(55,64,81)$ or their carbon skeletons are stored as fat. As well, the time course of protein synthesis observed during the continuous amino acid infusion seems to suggest that amino acids would be more efficiently utilized for maintaining lean body mass when given in divided doses (such as meal feedings) rather than with a continuous infusion application (2).

\subsubsection{AMINO ACID SUPPLEMENTATION AND RESISTANCE EXERCISE}

As previously discussed, during recovery from resistance exercise in the fasted state, muscle amino acid transport and protein turnover are accelerated, resulting in a less negative net protein balance $(49,59)$. Although protein balance is less negative in the fasted state, it does not shift to positive values. Research into the combined effects of 
resistance exercise and hyperaminoacidemia have revealed that the infusion of amino acids following resistance exercise, increased muscle protein synthesis more than at rest, and the normal exercise-induced increase in muscle protein breakdown was prevented, resulting in net protein accretion (8). Thus, provision of amino acids following resistance exercise has an anabolic effect on muscle. This area has not been extensively studied, therefore key studies in the area of post-exercise amino acid supplementation are examined in greater detail in the following section.

Intravenous infusion of amino acids is not a practical means of delivering amino acids to humans. Based on the results of Biolo and colleagues (8) Tipton and coworkers (85) examined the effect of orally administered amino acids post-exercise on net protein balance. It was observed that net protein balance was significantly higher during

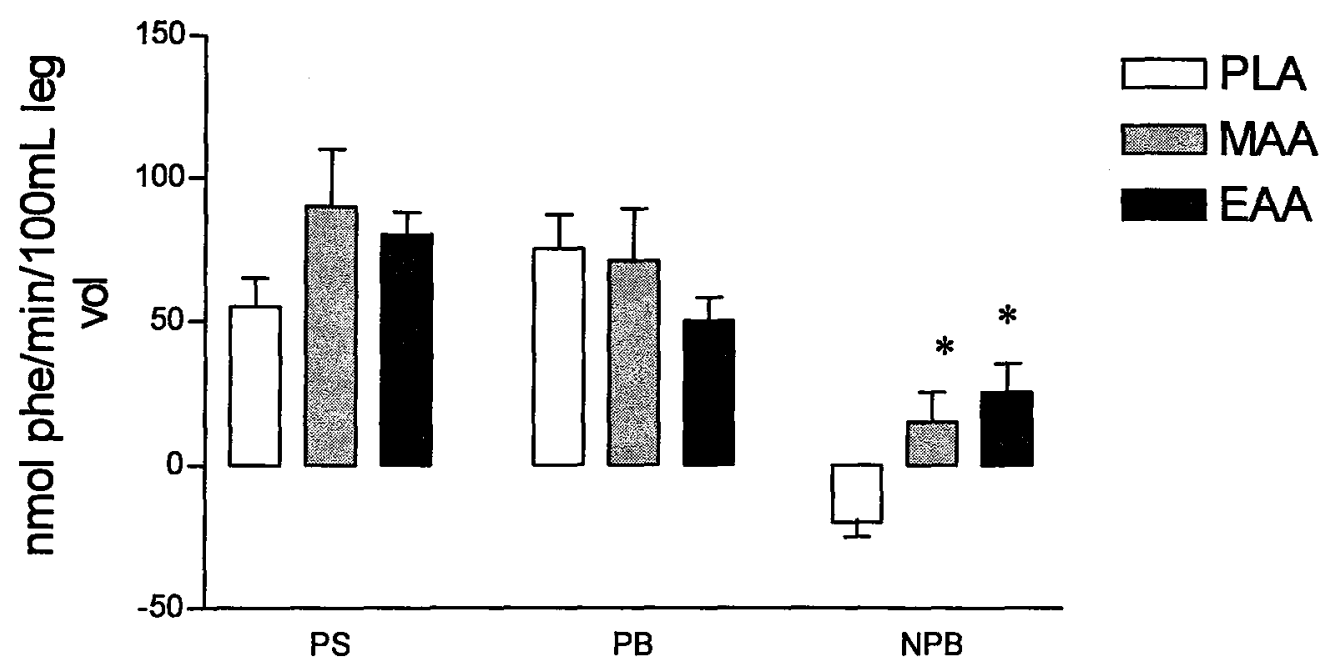

Figure 2. Muscle protein synthesis (PS), protein breakdown (PB), and net muscle protein balance (NPB) after exercise during consumption of solutions of placebo (PLA), $40 \mathrm{~g}$ of mixed amino acids (MAA), and $40 \mathrm{~g}$ of essential amino acids (EAA). *significantly different from PLA. Tipton et al. (85) 
ingestion of both essential amino acids and essential plus non-essential amino acids conditions compared to a placebo following a bout of resistance exercise (see Figure 2). Of importance, whereas net protein balance was negative during the placebo condition, it changed to positive following the ingestion of the solutions containing amino acids. Thus, the combination of amino acid ingestion following resistance exercise has a net anabolic effect greater than that of amino acid ingestion alone. Muscle net balance following ingestion of mixed amino acids (MAA) and essential amino acids (EAA) drinks were similar to the values previously reported by this group following infusion of amino acids (8). Tipton and colleagues (85) concluded that following resistance exercise an oral amino acid supplement was just as effective as amino acid infusion for stimulating muscle protein anabolism.

As mentioned previously, the combination of exogenous amino acids consumed orally (85) or infused intravenously (8), and resistance exercise are synergistic and combine as a potent stimulator of muscle protein synthesis. These conclusions are made based on the assumption that the stimulation of net muscle protein synthesis is additive to the balance that would occur during a normal day in the absence of exercise and amino acid ingestion. The increase in muscle protein synthesis in response to oral ingestion of amino acids following exercise is large, but it is also transient $(67,85,87)$. There exists uncertainty as to the impact of these transient responses on chronic changes in muscle metabolism and muscle mass.

Tipton and colleagues (84) measured the acute anabolic muscle response to resistance exercise and ingestion of essential amino acids, and extended their 
investigation over a $24 \mathrm{~h}$ period, at rest and following resistance exercise. It was observed that the muscle protein balance increased, primarily due to an acute stimulation of muscle protein synthesis by exercise and ingestion of EAA, and that the response was additive to the basal response over a full $24 \mathrm{~h}$ period (84). Thus, a bout of resistance exercise combined with consumption of amino acids results in stimulation of protein synthesis above normal day-to-day concentrations. Although this was observed over a 24 $\mathrm{h}$ period it might not be representative of the chronic changes observed with resistance training and amino acid ingestion. It is likely that the acute effects of amino acid

\section{Net Balance}

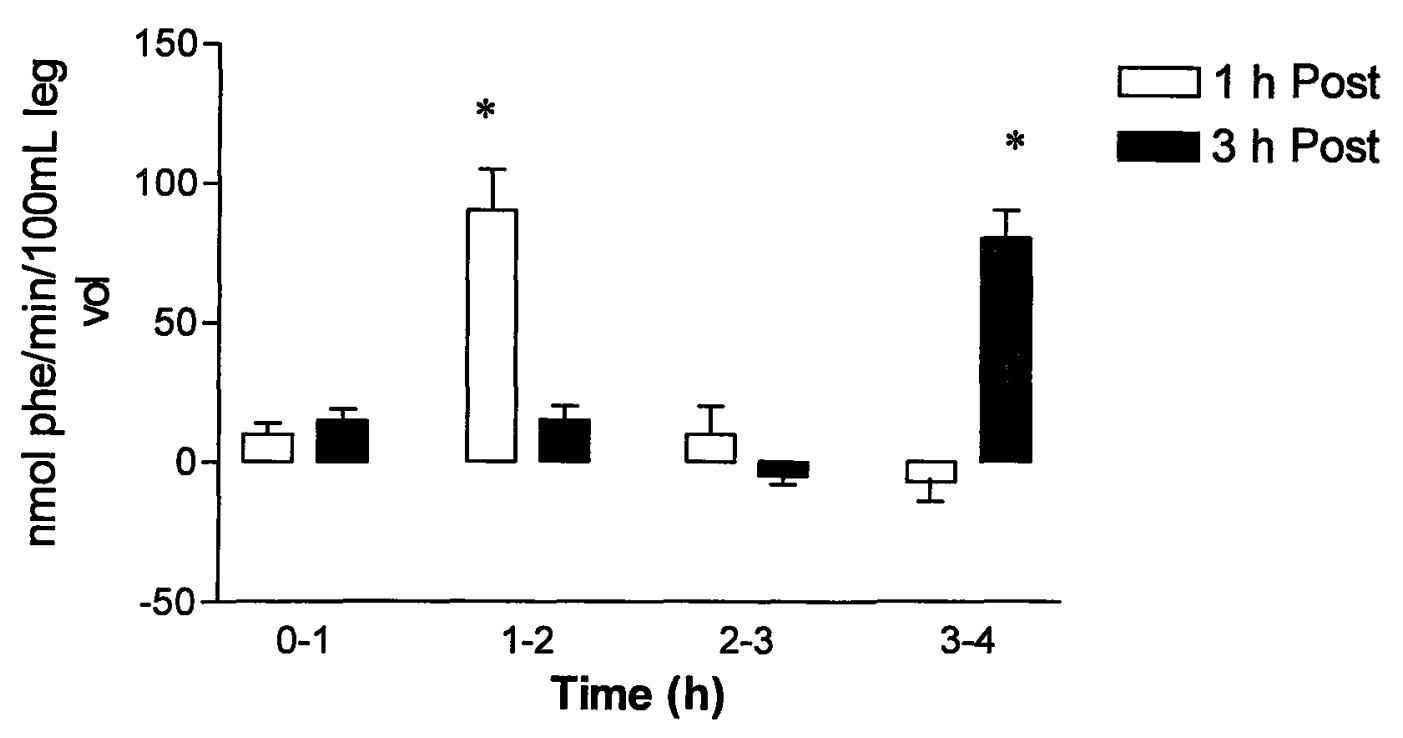

Figure 3: Phenylalanine net balance across leg after resistance exercise. EAA drink was ingested $1 \mathrm{~h}$ (1-h post) and $3 \mathrm{~h}$ (3-h post) postexercise. *Significantly different from placebo and predrink values, $P<0.05$. Rasmussen et al. (67)

ingestion and resistance exercise are attenuated with chronic training and supplementation, as is observed following resistance training (61), and will result in a 
blunted response to the stimulus. Future studies should examine the chronic changes in protein turnover due to exercise and amino acid supplementation.

\subsubsection{TIMING OF AMINO ACID SUPPLEMENTATION FOLLOWING RESISTANCE EXERCISE}

The work of Tipton and coworkers (84) revealed that any meal containing sufficient amino acids that is consumed within $24 \mathrm{~h}$ of resistance exercise results in a greater net muscle protein accretion than simply ingesting the amino acids alone. This leads to the question as to whether there are specific times following a bout of resistance exercise that may result in greater increases in net protein balance subsequent to the ingestion of amino acids. It was observed by Rasmussen and colleagues (67) that the timing of a carbohydrate/amino acid supplement did not have a pronounced impact on muscle protein net balance following resistance exercise. Subjects randomly consumed a treatment drink ( $6 \mathrm{~g}$ essential amino acids, $35 \mathrm{~g}$ sucrose) or a flavoured placebo drink $1 \mathrm{~h}$ or 3-h following a bout of resistance exercise on two separate occasions. Phenylalanine was infused and a three-compartment model for determination of leg muscle protein kinetics was used. They concluded that essential amino acids and carbohydrates stimulate muscle protein anabolism by increasing muscle protein synthesis to an equivalent extent when ingested at either 1-h or 3-h after resistance exercise (67) (see Figure 3). Thus, as long as amino acids are consumed within 3-h of resistance exercise the magnitude of net positive protein synthesis is not affected. 
Tipton and colleagues (87) later evaluated whether consumption of an oral essential amino acid carbohydrate supplement (EAC) before exercise results in a greater anabolic response than supplementation after resistance exercise. It was observed that during exercise, net protein balance switched from negative to positive following the consumption of EAC solution pre-exercise, and remained significantly higher than the post-exercise consumption group for 1-h post-exercise. They concluded that the response of net muscle protein synthesis to consumption of an EAC solution immediately before resistance exercise is greater than when the solution is consumed subsequent to exercise, primarily because of an increase in muscle protein synthesis as a result of increased delivery of amino acids (87). These findings are based upon an apparent feeding-induced increase in blood flow in the pre-exercise supplementation group. It must be pointed out that the blood flow values of the pre-exercise supplementation group are significantly higher than the post-exercise supplementation group, both during exercise, and 1-h postexercise. The higher blood flow values observed in the pre-exercise supplementation group translate into greater delivery and uptake of amino acids. Although amino acid delivery is dependant on blood flow (6), the high blood flow values observed in the preexercise supplementation group are inordinately high compared with the post-exercise supplementation group, which indicates that the higher positive balance in the preexercise supplemented group is due almost entirely to a blood flow effect.

Evidence indicates that significant increases in net protein balance do occur when amino acids are consumed 1-h and 3-h post-exercise (67), yet it is uncertain whether these acute and transient increases will translate into chronic muscle hypertrophy. In the 
elderly, evidence suggests that early intake of an oral protein supplement after resistance exercise is important for the development of hypertrophy in skeletal muscle in response to resistance training (26). In this study, 13 men trained for 12 weeks (three times per week) receiving oral protein $(10 \mathrm{~g})$ in liquid form immediately after $(\mathrm{P} 0)$, or 2-h after (P2) each training session. Significant muscle hypertrophy did occur in the P0 group, whereas no significant increases in muscle hypertrophy were present in the $\mathrm{P} 2$ group. It is unusual that in the P2 group there was no observation of hypertrophy following the 12 week training program since previous studies investigating the effects of resistance training in the elderly, where no specific dietary restrictions were imposed, found significant muscle hypertrophy in response to training $(16,29)$. The authors suggest that since dietary restrictions ended 2-h post-exercise the possibility remains that if the $\mathrm{P} 2$ group ingested a meal shortly following the supplement then the max effective dose of protein was exceeded and could have blunted the hypertrophic response (26). In support of the findings of Esmark and colleagues (26) a resistance training study involving rats found that the timing of a mixed meal ingestion after each training session influenced net protein synthesis over a 10 week training period. The group that was fed immediately post-exercise increased hind-limb muscle mass more than the group fed $4 \mathrm{~h}$ later, although the $4 \mathrm{~h}$ group did demonstrate hypertrophy (79).

Collectively, evidence suggests that post-exercise supplementation with amino acids is an important stimulus for muscle protein synthesis and allows for a positive net protein balance. There appears to be a minimum 3-h window in which amino acid supplementation stimulates protein synthesis following an acute bout of resistance 
exercise in young healthy humans. Timing of the post-exercise supplement does seem to be important in the elderly, although there is no evidence to corroborate the findings of Esmarck et al (26), in younger men and women or confirmation from another study in the elderly.

\subsection{MECHANISMS}

\subsubsection{INFLUENCE OF INSULIN}

Most studies examining the influence of insulin and its interaction with exercise and amino acids have been performed using rodent models; few have examined the relationship in humans. One study by Biolo and colleagues (9) examined the effect of a local insulin infusion post-exercise, on the rates of protein synthesis and breakdown. It was found that insulin infusion post-exercise did not affect the rate of protein synthesis, but significantly decreased the rate of protein degradation, thus creating a more positive protein net balance (9). Thus, since insulin creates an optimal environment for net protein gain to occur, this information appears to indicate that carbohydrates should be included in a post-exercise feeding in order to increase insulin concentrations and enhance skeletal muscle net protein balance. A study by Roy and colleagues (70) also found that carbohydrate supplementation post-exercise elevated insulin concentrations, and allowed for a decrease in myofibrillar protein breakdown, resulting in a more positive whole body protein balance. 
There appears to be a minimum concentration of insulin required for a full response of translation initiation and protein synthesis to occur. A study by Fluckey et al. (30) had rats either exercise or remain sedentary. The rats were subsequently subjected to bilateral hind-limb perfusion in which one leg was perfused with medium containing insulin and the other with medium devoid of the hormone. The perfusion medium additionally contained physiological concentrations of amino acids. It was observed that in the presence of insulin, protein synthesis was stimulated in the perfused exercised muscle preparations compared with those from sedentary rats. In contrast, the exerciseinduced stimulation of protein synthesis was not observed when insulin was eliminated from the perfusion medium (30). These findings concur with previous findings and indicate that insulin, in combination with prior contractions, induces a stimulation of protein synthesis and without the presence of this hormone there is a lack of response altogether.

In rodents, it has been found that eukaryotic initiation factor $2 \mathrm{~B}(\mathrm{eIF} 2 \mathrm{~B})$ is responsible for the initiation of protein synthesis following resistance exercise $(39,47)$. Subsequent research has observed an interaction between insulin, eIF2B and resistance exercise. It appears that a minimal concentration of plasma insulin is required to generate a stimulation of muscle protein synthesis and eIF2B activity in response to resistance exercise $(27,39,41,42)$. 


\subsubsection{AVAILABILITY OF AMINO ACIDS}

Evidence from human studies strongly suggests that amino acid availability postexercise allows net protein synthesis to occur in skeletal muscle $(8,67,84,85,86,87)$. Recent evidence in swine has found that reduced amino acid availability inhibits muscle protein synthesis and decreases activity of eIF2B (44). Kobayashi and colleagues (44) concluded that a decline in plasma amino acid concentrations below the normal basal value signals an inhibition of muscle protein synthesis, and the corresponding changes in eIF2B activity suggest a possible role for this peptide chain initiation factor in mediating the response (44). This finding is intriguing since it seems that both insulin concentrations $(9,30)$ and the availability of amino acids (44) can influence the activity of eIF2B and modulate muscle protein synthesis. Future studies in this area are needed in order to verify the interaction.

\subsubsection{INFLUENCE OF PROTEIN SOURCE}

Proteins elicit different postprandial responses depending on their source and composition, which could result in varying concentrations of incorporation into the different protein pools within the body. So called "fast" and "slow" proteins have been shown to differently modulate postprandial protein accretion (3). Whey and casein, the protein fractions found in milk, have been recognized as fast and slow proteins respectively $(3,21)$. Whey protein induces a dramatic but short-lived increase in plasma 
amino acids while casein induces a more prolonged plateau of moderate hyperaminoacidemia, likely due to a slowed rate of gastric emptying and slower digestion and assimilation $(3,21)$. The underlying responses of protein turnover induced by these two protein fractions are quite different. Whole body protein breakdown was inhibited by $34 \%$ after casein ingestion but not after whey, while postprandial protein synthesis was stimulated by $68 \%$ with a whey protein meal and to a lesser extent (31\%) by a casein meal. In addition, whole body leucine oxidation was lower following consumption of casein than with whey protein. The end result was that net leucine balance over the $7 \mathrm{~h}$ period following a casein or whey meal was more positive with casein than with whey (3, 21). From the results of these studies it can be concluded that the speed of amino acid absorption after protein ingestion has a major impact on the postprandial metabolic response to a single protein meal. The slowly absorbed casein promotes postprandial protein deposition by an inhibition of protein breakdown without excessive increases in amino acid concentration; by contrast, a fast dietary protein stimulates protein synthesis but also oxidation. The observed decrease in proteolysis following consumption of casein can likely be attributed to the duration of the postprandial hyperaminoacidemia. Amino acids themselves have been shown to inhibit proteolysis (33) and the hyperaminoacidemia is much more prolonged with slow than with fast proteins $(3,21)$. The observed decrease in protein breakdown is unlikely due to insulin since the extent of insulinemia was either not different (3) or higher following the fast proteins (21). The two major constituent proteins in milk are whey and casein, but they are found in quite different proportions, $80 \%$ casein and $20 \%$ whey protein indicating that milk on 
aggregate would act like a slow protein rather than a fast protein due to its larger casein protein fraction (14).

The quality of milk and soy proteins have been assessed both independently and compared directly. Several studies have found that isolated soy protein is of high nutritional quality, comparable to that of animal protein sources $(38,73,99)$, and the level of amino acids in plant protein, including soy protein isolates is much higher (per unit of protein) than that required by adults (100). Soy and milk have been directly compared using the $\mathrm{N}$ balance technique. These comparisons have highlighted the fact that well processed isolated soy proteins are indistinguishable from milk as a protein source for maintenance of short-term $\mathrm{N}$ balance in adult human nutrition $(38,73)$. On the basis of this evidence it can be assumed that the quality of isolated soy protein is high and if differences do exist between soy and milk proteins in their ability to build skeletal muscle, it is not due to differences in the quality of the protein. In an early review examining soy protein, Young hypothesized that the differences between milk and soy milk in building skeletal muscle is due to the difference in their pattern of digestion (100).

Recently published studies have found that milk and soy proteins display varying posprandial kinetics, milk acting like a slow protein and soy as a fast protein. The differences in postprandial nitrogen metabolism of intact dietary proteins is different following ingestion of milk and soy, mainly because of a greater deamination of soy amino acids than of milk amino acids $(13,31,46,50)$, and of their differing capacity to support protein synthesis (23). In a recent study by Bos et al (14) that directly compared the postprandial kinetics of dietary amino acids from soy and milk in humans, it was 
found that soy derived amino acids were digested more rapidly and were directed toward both deamination pathways and liver protein synthesis more than milk derived amino acids. They hypothesized that differences between soy and milk protein may have arisen from the combined influence of a relatively unbalanced amino acid composition in the soy protein and its lower digestibility, resulting in a less favorable pattern of amino acids reaching the periphery (14). A study by Fouillet et al. (28) utilized compartmental modeling techniques to simulate the kinetics of dietary $\mathrm{N}$ movement following the ingestion of sucrose and soy or sucrose and milk proteins. They found that protein synthesis efficiencies in the splanchnic bed were significantly affected by the protein source in the meal, and reached 23 and $30 \% 8 \mathrm{~h}$ after milk proteins and soy proteins ingestion respectively. Conversely protein synthesis efficiencies in the peripheral tissues reached 32 and $26 \% 8 \mathrm{~h}$ after milk and soy protein ingestion respectively (28). This would indicate that milk protein promotes greater accretion of peripheral protein, possibly skeletal muscle, than soy protein. The lower whole body retention of dietary $\mathrm{N}$ observed experimentally with soy compared with milk protein was associated with the following: 1) a more rapid intestinal transit and absorption of dietary $\mathrm{N}$ from soy protein; 2) its increased rate of transfer of amino $\mathrm{N}$ to urea, concurrent with its similar sequestration in the splanchnic bed; and 3) subsequent reduction in uptake by the peripheral area (28). It is known that milk proteins used in the Fouillet study (28) contained higher concentrations $(\sim 120 \%)$ of branched chain amino acids (BCAA) than soy proteins, and these amino acids that are transferred largely to extrasplanchnic tissues $(5,92)$. Certain BCAA, in particular leucine are also stimulators of muscle protein anobolism $(39,94)$, 
and a higher proportion of BCAA could explain the higher peripheral protein synthesis efficiencies reported following milk protein ingestion versus soy protein (28).

The synergistic effect of resistance exercise and post-exercise protein feeding on overall net protein balance has been well documented $(8,26,51,67,85)$. A study by Wilkinson et al. (92) examined the effect of milk versus soy drink ingestion following heavy resistance exercise. They observed greater protein synthetic rates and net amino acid uptake in skeletal muscle following milk ingestion compared to soy (92), suggesting greater overall accretion of skeletal muscle in individuals consuming milk post-exercise than those consuming soy. It does appear that milk proteins or protein of an animal origin, promote skeletal muscle accretion of a larger magnitude than that of soy proteins or protein of a vegetable origin.

\subsubsection{CARBOHYDRATE INGESTION}

Insulin and exercise are well known regulators of protein metabolism $(6,93)$. At rest, insulin has a stimulatory effect on muscle protein synthesis, which is observed only when amino acid availability is maintained or kept high $(6,9)$. However, while insulin inhibits proteolysis it has no effect on muscle myofibrilar protein breakdown $(6,9)$. Interestingly, following resistance exercise the effect of insulin is reversed and no additional increase in muscle protein synthesis is observed $(9,12,70)$, while the exerciseinduced increase in muscle protein breakdown is significantly attenuated by insulin ( 9 , $12,43,51)$. There is some debate over the effect of insulin on protein synthesis rates 
since evaluation of the effect of insulin on muscle is complicated by the fact that systemic insulin infusion causes a pronounced hypoaminoacidemia. This decrease in amino acid concentrations tends to counteract any direct action of insulin to stimulate muscle protein synthesis (95). A practical method of elevating post-exercise insulin concentrations is by consumption of a carbohydrate containing meal. This method has been proven to significantly elevate glucose and insulin concentrations sufficiently to result in a decrease in myofibrilar protein degradation $(11,51,70)$.

Carbohydrate and protein are synergistic in their ability of promote protein accretion $(31,51,67)$. At rest the addition of sucrose to a protein meal halved the early $(0-2 \mathrm{~h})$ deamination peak of dietary nitrogen and reduced endogenous protein oxidation over the first $4 \mathrm{~h}$; both were reduced by $18-24 \%$ over the $8 \mathrm{~h}$ period after the meal compared to a protein meal (50). Similarly, Gaudichon and colleagues (31) found that carbohydrates reduced amino acid catabolism during the postprandial phase, both directly and through their insulin releasing effect. Mariotti et al (50) found that there was a marked delay of gastric emptying with a protein sucrose meal compared to a protein meal, which caused the soy protein to act more like a slow protein when ingested with carbohydrate allowing for a more moderate hyperaminoacidemia and promoting protein accretion. An underlying mechanism for this effect may be related to p70 S6 kinase. A recent study found that insulin and amino acids activate p70 S6 kinase through different pathways, and leucine stimulates protein synthesis through a nutrient signaling mechanism that is independent of insulin (34). Following resistance exercise the combined effect on net muscle protein synthesis of carbohydrate and amino acids given 
together is roughly equivalent to the sum of the independent effects of either given alone (51). During the 3-h period after ingestion of carbohydrate plus amino acids, net muscle protein synthesis was significantly greater than following carbohydrate ingestion alone (51). Although carbohydrate ingestion does have an influence on overall net protein balance the amplitude of its effect is small in comparison to amino acids alone (12). The main benefit of carbohydrate ingestion following exercise is when it is taken in combination with protein (51).

Although post-exercise provision of an amino acid containing meal is essential for accretion of skeletal muscle, controversy exists with respect to the importance of immediate provision of this meal. Some evidence suggests that in the elderly the immediate provision of amino acids is crucial (26), whereas acutely, in young males it does not seem to be essential (67). The presence of increased concentrations of insulin has been identified as being a fundamental component in promoting skeletal muscle accretion. The provision of carbohydrate alone following resistance exercise increases insulin levels and allows for a more positive skeletal muscle net protein balance postexercise, mainly by reducing protein breakdown levels. Moreover, a post-exercise meal containing both amino acids and carbohydrate is more effective at promoting skeletal muscle net positive balance than either consumed alone. Milk and soy proteins elicit different postprandial kinetics, and milk proteins are more effective at stimulating protein synthesis in the peripheral area than soy proteins. Following resistance exercise milk proteins are more effective than soy proteins for increasing protein synthetic rates and net 
amino acid uptake in skeletal muscle. The differences between milk and soy are mainly due to differences in digestion kinetics and not in their amino acid composition.

\subsection{STATEMENT OF PURPOSE}

The provision of a protein containing meal post-exercise is crucial for the accretion of skeletal muscle $(7,8,84,85,87,92)$. How the source of this protein can affect the degree of hypertrophy while resistance training is yet undetermined. At rest it has been demonstrated that milk proteins are more effective at promoting protein synthesis in the peripheral areas than soy proteins (28). Following resistance exercise milk proteins are more effective at stimulating skeletal muscle protein synthesis and net amino acid uptake (92). The aim of the present study was to test the hypothesis that the post-exercise consumption of milk will be more effective than an isoenergetic and isonitrogenous control drink from soy (PEC), and both the milk and soy will be more effective than an isoenergetic control $(\mathrm{CON})$ at promoting resistance training adaptations observed in increases in the following variables:

1. Fat and bone free mass (FBFM)

2. Muscle fibre area

3. 1 RM Strength 


\section{Chapter II}

The effect of differing post-exercise macronutrient consumption on resistance training-induced adaptations in novices 


\subsection{INTRODUCTION}

Resistance exercise training is a potent stimulus for skeletal muscle hypertrophy $(19,45,72,82)$. Acutely, resistance exercise stimulates skeletal muscle protein synthesis rates and allows for a more positive protein net balance $(49,59)$. Although less negative, net protein balance does not become positive until after the consumption of a postexercise protein containing meal $(7,8,84,85,87,92)$. Hence, protein is an important macronutrient to include in a post-exercise meal. Moreover, while the provision of carbohydrate alone in the post-exercise period promotes a more positive protein balance, a net positive protein balance is not attained $(12,51)$.

Postprandial protein metabolism in response to feeding is affected by the protein source $(3,21,22)$. Aptly named "fast" and "slow" proteins demonstrate differing protein kinetics $(3,21)$. Fast proteins such as whey have a lower postprandial retention rate compared to a slow protein such as casein $(3,21)$. Milk (20\% whey, $80 \%$ casein protein fractions) and soy proteins have been classified as slow and fast protein sources respectively $(14,28)$, and the muscle protein synthetic response in different tissue compartments varies following ingestion of each source. Milk proteins promote a greater protein synthesis efficiency (defined as the fraction of intracellular amino acids flux of appearance that is incorporated into protein (28)) within the peripheral tissues, most likely muscle, whereas soy proteins promote greater protein synthesis efficiency in the splanchnic bed (28). These data imply that milk may be superior for promotion of skeletal muscle protein accretion than soy when consumed post-exercise, because milk 
proteins would provide a greater stimulus for muscle protein synthesis. The purpose of the present study was to examine the influence of varying post-exercise macronutrient consumption (milk, soy beverage and maltodextrin) on resistance training adaptations in young novice weightlifters. Our hypothesis was that individuals consuming milk immediately and 1-h post-exercise would observe larger gains in strength, lean muscle mass, and muscle fibre area than a group consuming a soy beverage, and both the milk and soy beverage groups would observe larger gains than a group consuming a maltodextrin only beverage.

\subsection{METHODS}

36 young healthy men $(22.5 \pm 0.6 \mathrm{y}, 82.1 \pm 2.2 \mathrm{~kg}, 1.8 \pm 0.01 \mathrm{~m}, 25.6 \pm 0.7$ $\mathrm{kg} / \mathrm{m}^{2}$ ) were recruited to participate in the study. Volunteers completed a routine medical screening questionnaire, and based on their responses all were deemed healthy. Written informed consent was obtained from all volunteers. The study was approved by the Hamilton Health Sciences Research Ethics Board. None of the participants were engaged in regular physical activity $(<2 \mathrm{~d} / \mathrm{wk})$ at the start of the study and had not done so for the previous 6 months.

\subsubsection{EXPERIMENTAL PROTOCOL}

Prior to the study and during the $6^{\text {th }}$ and $12^{\text {th }}$ weeks of training participants were required to complete $3 \mathrm{~d}$ weighted diet records (analyzed using Nutritionist V, First.Data 
Bank, San Bruno, Ca) to determine macronutrient consumption. Subjects were randomly assigned to consume either milk (MLK) ( $\mathrm{n}=12$; fat free milk), an isonitrogenous isoenergetic control (PEC) $(n=12$; soy beverage) or an isoenergetic control $(\mathrm{CON})(n=12$; maltodextrin beverage) drink consumption groups using single blinded allocation. All drinks had similar strawberry flavor and were visually opaque and of similar colour. Participants consumed one $500 \mathrm{~mL}$ drink immediately post-exercise under direct supervision of an investigator, and a second $500 \mathrm{~mL}$ drink 1-hr post-exercise.

Participants were instructed to be at least 2-h post-prandial before training and were instructed to refrain from consumption of foodstuffs for 2 -h post-exercise, with the exception of water. Compliance with the immediate post-exercise drink was $100 \%$ because of direct investigator supervision. The 1-h post-exercise drink consumption compliance was reported to be $100 \%$ by the subjects.

Following the pre-training testing procedures two subjects dropped out of the study for personal reasons, one from the PEC and one from the CON groups. Thus a total of 11 subjects remained in both the PEC and CON groups, who completed all aspects of testing/training. All subjects completed 12 weeks of a whole body split routine resistance training program, $5 \mathrm{~d} / \mathrm{wk}$ and pre, mid and post-testing as described below. Compliance with the training program was $98 \pm 0.4 \%$. 


\subsubsection{PRE, MID AND POST TESTING}

One repetition maximal strength (1RM) testing was conducted over a $3 \mathrm{~d}$ period (days 1-3) for each of 13 exercises pre, 4 wk, 8 wk and post training. The legs were tested on the first day (leg press, leg curl, leg extensions, standing calf raises), followed by pushing exercises (seated military press, bench press, vertical bench press, chest fly, and seated machine triceps extensions), and, finally, pulling exercises (latissimus pull-down, seated wide-grip row, seated narrow low row, and seated biceps curl). Subjects initially performed a warm-up set of 8-10 repetitions at approximately $50 \%$ of their estimated 1RM. The first set was the first attempt at the predicted 1RM. A successful lift was judged as being through the full range of motion of the exercise and was performed with proper technique as assessed by an investigator. There was a 2-min rest period between each successive attempt of a new 1RM. If a subject could not lift the initial $1 R M$, the weight was reduced accordingly and a 2 -min rest period was provided before the next 1RM attempt. $1 \mathrm{RM}$ tests on the guided motion machines (all except leg press) subjects started from the initial position of the machine (either at full extension or flexion depending on the exercise) and progressed through the range of motion unaided. The leg press testing consisted of subjects initially having legs at full extension, then lowered the weight until knee angle was $90^{\circ}$ of flexion and subjects then lifted the weight into full extension.

Percutaneous muscle biopsies were taken from the vastus lateralis muscle under local anaesthetic ( $2 \%$ Lidocaine) using a $5 \mathrm{~mm}$ Bergstrom needle modified for manual 
suction. Samples were immediately dissected of all fat and connective tissue, oriented and mounted in optimal cutting temperature (OCT) embedding medium that was prechilled in isopentane-cooled in liquid nitrogen, snap frozen, and stored at $-80^{\circ} \mathrm{C}$ until subsequent analysis. The remainder of each biopsy was frozen directly in liquid nitrogen.

Body composition (total body mass (TBM)), fat-free mass (FFM), fat and bonefree mass (FBFM) and body fat mass and percentage were assessed using dual energy $x-$ ray absorptiometry (DXA: Model QDR-1000/W, Hologic Inc., Waltham, MA). Participants were scanned during the same time of day pre and post. Whole body scans were performed from head to toe in the single beam mode and bone mineral content (BMC), fat, and lean mass were calculated using the version 5.56 software. All participants were scanned with their hands suppinated at their sides and feet between 20$30 \mathrm{~cm}$ apart. All scans were performed by the same investigator and positions were recorded in order to replicate them during post training. During each test the standard bar was placed to the right of the subject and a phantom spine was scanned each day for dayto-day reliability. In a reproducibility experiment using this machine it was found that the coefficients of variation (CV) were $1.6,1.4$, and $1.8 \%$, for whole-body $\mathrm{BMC}$, lean mass, and fat mass, respectively (19).

All participants were also required to have a one-time response to a leg workout and supplement consumption evaluated during the $7^{\text {th }}$ week of training. Participants arrived in the laboratory at least 2 -h post-feeding as instructed throughout the training program and had a plastic catheter $(20 \mathrm{Ga})$ inserted into their anticubital vein. Blood samples were obtained at rest, immediately post-exercise, and every 30 min up to $2-\mathrm{h}$ 
post-exercise. Samples were collected in tubes containing heparin for plasma analysis, glucose was analyzed immediately (Yellow Springs Instruments, Yellow Springs, OH, USA), the remainder was centrifuged at $5000 \mathrm{rpm}$ for $5 \mathrm{~min}$ at $4^{\circ} \mathrm{C}$. Plasma was transferred and frozen $\left(-20^{\circ} \mathrm{C}\right)$ until further analysis (see below).

\subsubsection{EXERCISE TRAINING}

Following all pre-training testing, participants began a full body split resistance training program $5 \mathrm{~d} /$ wk. Sessions were split into one of three training groups (see Table 1), the muscle group that was trained only once the prior week began the following week. All training sessions were monitored by an investigator and a ratio of no more than 2 participants to 1 investigator was maintained throughout the study to ensure proper technique and compliance with exercise intensity.

Table 1. Exercise groupings

\begin{tabular}{|c|c|c|c|}
\hline & Day 1 (Legs) & Day 2 (Pushing) & Day 3 (Pulling) \\
\hline & & Military press, & Lateral pull down, \\
& Leg press, & Bench press, & Wide row, \\
Exercises & Leg extension, & Seated bench press, & Narrow row, \\
& Leg curl, & Chest Flys, & Back flys, \\
& Seated calf raises & Seated tricep & Seated bicep curls \\
\hline
\end{tabular}

The program utilized only guided motion and cable machines (Badger Magnum, Milwaukee, WI) to ensure safety and to reduce the learning required for performance of the exercises. Training was initiated at approximately $80 \%$ of pre $1 \mathrm{RM}$ for each exercise, a goal of 2 sets of 10-12 repetitions and was set for weeks 1 and 2 . 
Table 2. Exercise training protocol

\begin{tabular}{|l|l|l|}
\hline Week 1-2 & 2 Sets & 10-12 reps \\
\hline Week 3-5 & 3 Sets & $10-12$ reps \\
\hline Week 6-7 & 3 Sets, with $3^{\text {rd }}$ set to failure & 8-10 reps \\
\hline Week 8-10 & 3 Sets, with $3^{\text {rd }}$ set to failure & 6-8 reps \\
\hline Week 11-12 & 3 Sets, with $3^{\text {rd }}$ set to failure & 5-6 reps \\
\hline
\end{tabular}

In subsequent exercise sessions intensity was adjusted so that 3 sets of 6-12 repetitions were performed, with set 3 being performed to failure (see Table 2). The load was continuously adjusted according to subject performance in order to remain within the desired repetition range. Training logs were kept in order to record training intensity and volume of each session. Subjects were instructed not to engage in any new additional training but were encouraged to maintain previous activity levels. Twenty four participants had $100 \%$ compliance and 10 had $90 \%$ or above for an overall compliance rate of $98 \pm 0.4 \%$.

\subsubsection{HISTOCHEMICAL ANALYSIS}

The OCT embedded biopsy samples were serially sectioned (10 $\mu \mathrm{m}$ thick) on a cryostat microtome (Model HM500OM, Micron International, Walldorf, Germany) at a sample and cabinet temperature of $-20^{\circ} \mathrm{C}$. Samples were stained for myosin ATPase activity after preincubation at a $\mathrm{pH}$ of $4.6(15)(50 \mathrm{mM}$ potassium acetate, $17.5 \mathrm{mM}$ calcium chloride) for a duration of $7 \mathrm{~min}$ with pre and post training samples assayed simultaneously. Slides were then rinsed in distilled water and incubated in 3mM ATP using an alkaline solution ( $75 \mathrm{mM}$ glycine, $40.5 \mathrm{mM}$ calcium chloride, $75 \mathrm{mM} \mathrm{NaCl}$, 
$67.5 \mathrm{mM} \mathrm{NaOH}$, adjusted to $\mathrm{pH} 9.4$ ) for $45 \mathrm{~min}$ at $37^{\circ} \mathrm{C}$ and agitated at regular intervals in a temperature controlled incubator shaker (G24 Environmental Incubator Shaker, New Brunswick Scientific Co., New Brunswick, NJ). Slides were then rinsed in distilled water and incubated in $1 \% \mathrm{CaCl}_{2}$ for $3 \mathrm{~min}$ at room temperature. Slides were once again rinsed in distilled water and incubated in $2 \% \mathrm{CoCl}_{2}$ for $3 \mathrm{~min}$ at room temperature. Slides were then rinsed in distilled water and incubated in $1 \%$ ammonium sulphide for 30 seconds at room temperature. Slides were then rinsed a final time in distilled water and dehydrated by submersing for $2 \mathrm{~min}$ in the following ethanol concentrations $(70,80,90,95$ and 100\%). Samples were then cleaned twice using xylene. Slides were blotted dry using kimwipes and coverslips were mounted using Permount (Fisher SP15) and allowed to dry overnight.

A total of 100-500 fibres were available for analysis from each sample. Fibre analyses were performed using image analysis software (Image Pro Plus, Media Cybernetics, Silver Springs, MD) interfaced with a microscope (Olympus BX60, Melville, NY) and a digital camera (SPOT Diagnostic Instruments, Inc., Sterling Heights, MI). Custom macro programs within the software were used to calculate individual fibre areas and raw data was exported to an Excel Spreadsheet (Microsoft), percent fibre area and percent fibre type were calculated within Excel. Three to four fibre types were identified per sample (I, IIa, IIx, and IIax) from the staining pattern by setting cut-off limits resulting in the creation of optical density 'bins' according to the darkest (type I), lightest (type IIa) and intermediate (type IIx) fibres. Sample images were converted to 8bit, 256 grayscale images, which linearly scale each pixel and assign values from between 
0 (black) to 255 (white). By setting lower and upper threshold values optical density bins were created that were: $0-95$ for dark areas, $100-175$ for intermediate areas, $180-255$ for light areas. Using these cutoffs the three fibre types were more objectively classified.

\subsubsection{INSULIN AND GLUCOSE ANALYSIS}

Insulin concentrations were analyzed by radioimmunoassay (RIA) (Coat-A-Count, Diagnostic Products Corporation, Los Angeles, CA). Briefly, frozen serum samples were thawed vortexed and centrifuged to clear lipemic samples. $200 \mu \mathrm{L}$ of sample and $1 \mathrm{~mL}$ of ${ }^{125} \mathrm{I}$ insulin were added to $12 \times 75 \mathrm{~mm}$ polypropylene insulin-specific antibody coated tubes and gently vortexed. Samples were analyzed in duplicate for post, $30 \mathrm{~min}$ post, 60 min post and $120 \mathrm{~min}$ post. Tubes were incubated for $24 \mathrm{hrs}$ at room temperature $\left(-21^{\circ} \mathrm{C}\right)$ and then decanted thoroughly. Radioactivity was analyzed using a gamma counter (5000 Minaxi Auto Gamma, Packard, Downers Grove, IL) for a duration of 1 min. Glucose was analyzed immediately following sample collection on whole blood (2300 STAT Plus-D, Yellow Springs Instrument, CO, USA)

\subsubsection{STATISTICAL ANALYSIS}

All anthropometric and histochemical data were analyzed using analysis of variance (ANOVA) with a 3 by 2 design (between factor $=$ CON/MLK/PEC; within factor $=$ PRE/POST training), and analysis of covariance (ANCOVA) was used on type II fibre area with pre fibre area used as a covariate. Glucose data were analyzed using 
ANOVA with a 3 by 6 design (between factor $=$ CON/MLK/PEC; within factor $=$ PRE/POST; 30/60/90/120 min post-exercise). Insulin data were analyzed using ANOVA with a 3 by 4 design (between factor $=\mathrm{CON} / \mathrm{MLK} / \mathrm{PEC}$; within factor $=$ POST/30/60/120). Tukey post hoc analysis was employed to make pair-wise comparisons following identification of significant interactions. Correlation matrices, using Pearson's product correlations, were used to analyze the relationship between energy intake and lean mass gains, protein intake and lean mass gains, and lean mass gains and strength gains. Statistical significance was considered to be at level $P \leq 0.05$. Statistical analysis was performed using a computerized statistical package (Statistica 5.1, Statsoft, Tulsa, $\mathrm{OH})$. 


\subsection{RESULTS}

\subsubsection{ANTHROPOMETRY}

Thirty four subjects, $22.5 \pm 0.6 \mathrm{y}, 82.1 \pm 2.2 \mathrm{~kg}, 1.8 \pm 0.01 \mathrm{~m}, 25.6 \pm 0.7 \mathrm{~kg} / \mathrm{m}^{2}$ completed training. There were no differences between groups before training MLK; 23 $\pm 1 \mathrm{y}, 24.7 \pm 1.0 \mathrm{~kg} / \mathrm{m}^{2}, \mathrm{PEC} ; 22 \pm 0.7 \mathrm{y}, 27.8 \pm 1.1 \mathrm{~kg} / \mathrm{m}^{2}, \mathrm{CON} ; 22.7 \pm 1.4 \mathrm{y}, 24.5 \pm 1.4$ $\mathrm{kg} / \mathrm{m}^{2}$. There was an increase in total mass post training in all groups $(\mathrm{P}<0.05)$. All three groups also increased FBFM post-training $(\mathrm{P}<0.05)$ with a weak trend observed; MLK had the greatest gains in FBFM (5.5\%), PEC observed slightly lower gains (4.0\%), and $\mathrm{CON}$ had the smallest gains (3.6\%) following training (time by group interaction, $\mathrm{P}=0.47)$. A decrease in body fat percentage was observed following training $(\mathrm{P}<0.05)$ in all groups, whereas total fat mass was unchanged over the training period (Table 3, Figure 4).

\subsubsection{DIETARY ANALYSIS}

There were no differences in habitual energy intake or the percentage of macronutrient ingestion at baseline. Protein ingestion increased during the study above habitual intakes for all groups in both absolute ingestion and relative to body mass $(\mathrm{P}<0.05)$. The relative ingestion of protein also increased throughout the study in all groups $(\mathrm{P}<0.05)$. No differences were observed for $\mathrm{CHO}$ and fat ingestion throughout the study (Table 4). 
Table 3. Body composition determined by DXA

\begin{tabular}{|c|c|c|c|c|c|c|c|c|c|}
\hline & \multicolumn{3}{|c|}{ CON } & \multicolumn{3}{c|}{ MLK } & \multicolumn{3}{c|}{ PEC } \\
\hline & PRE & POST & $\% \Delta$ & PRE & POST & $\% \Delta$ & PRE & POST & $\% \Delta$ \\
\hline $\begin{array}{c}\text { Total Mass } \\
(\mathrm{kg})\end{array}$ & $77.5 \pm 2.2$ & $79.5 \pm 4.6^{*}$ & $2.6 \pm 0.8$ & $77.9 \pm 3.2$ & $81.1 \pm 2.7^{*}$ & $4.4 \pm 1.2$ & $86.8 \pm 4.2$ & $89.7 \pm 4.7^{*}$ & $3.2 \pm 1.5$ \\
\hline $\begin{array}{c}\text { Body Fat } \\
\%\end{array}$ & $16.7 \pm 1.9$ & $16.1 \pm 1.7^{*}$ & $-1.9 \pm 3.1$ & $15.8 \pm 1.1$ & $14.9 \pm 1.0^{*}$ & $-4.4 \pm 2.1$ & $19.8 \pm 1.5$ & $19.3 \pm 1.5^{*}$ & $-2.6 \pm 3.2$ \\
\hline $\begin{array}{c}\text { Fat Mass } \\
(\mathrm{kg})\end{array}$ & $13.5 \pm 2.1$ & $13.3 \pm 1.8$ & $-0.8 \pm 4.2$ & $12.7 \pm 1.3$ & $12.3 \pm 1.1$ & $-2.2 \pm 3.2$ & $17.5 \pm 1.8$ & $17.7 \pm 2.0$ & $1.0 \pm 4.7$ \\
\hline $\begin{array}{c}\text { Fat Bone } \\
\text { Free Mass } \\
(\mathrm{kg})\end{array}$ & $61.2 \pm 2.5$ & $63.4 \pm 2.7^{*}$ & $3.6 \pm 0.9$ & $62.5 \pm 1.9$ & $65.7 \pm 1.6^{*}$ & $5.5 \pm 1.0$ & $66.2 \pm 2.8$ & $68.9 \pm 3.1^{*}$ & $4.0 \pm 0.8$ \\
\hline
\end{tabular}

Results are mean $\pm \mathrm{SE}$

${ }^{*}$ Significant main effect for Time $(\mathrm{P}<0.05)$ 
Table 4. Diet analysis before training and at 6 and 12 weeks of training

\begin{tabular}{|c|c|c|c|c|c|c|c|c|c|}
\hline & \multicolumn{3}{|c|}{ CON } & \multicolumn{3}{|c|}{ MLK } & \multicolumn{3}{|c|}{ PEC } \\
\hline & PRE & MID & POST & PRE & MID & POST & PRE & MID & POST \\
\hline $\begin{array}{c}\text { Energy Intake } \\
\text { (Mj/day) }\end{array}$ & $12.4 \pm 1.2$ & $14.4 \pm 1.5$ & $14.6 \pm 1.7$ & $12.1 \pm 0.8$ & $12.3 \pm 0.9$ & $13.3 \pm 0.8$ & $12.2 \pm 0.6$ & $12.5 \pm 1.1$ & $12.3 \pm 1.5$ \\
\hline $\begin{array}{c}\text { Protein Intake } \\
(\mathrm{g} / \mathrm{kg} / \text { day })\end{array}$ & $1.3 \pm 0.1$ & $1.7 \pm 0.2^{*}$ & $1.8 \pm 0.3^{*}$ & $1.4 \pm 0.1$ & $1.5 \pm 0.1^{*}$ & $1.6 \pm 0.1^{*}$ & $1.2 \pm 0.1$ & $1.6 \pm 0.2^{*}$ & $1.4 \pm 0.2^{*}$ \\
\hline $\begin{array}{c}\text { Protein intake } \\
\text { (g/day) }\end{array}$ & $100 \pm 6$ & $134 \pm 15^{*}$ & $139 \pm 18^{*}$ & $114 \pm 10$ & $123 \pm 9 *$ & $134 \pm 9 *$ & $101 \pm 9$ & $137 \pm 15^{*}$ & $128 \pm 13^{*}$ \\
\hline $\begin{array}{c}\text { CHO intake } \\
\text { (g/day) }\end{array}$ & $416 \pm 45$ & $460 \pm 36$ & $448 \pm 52$ & $376 \pm 34$ & $343 \pm 37$ & $395 \pm 29$ & $364 \pm 40$ & $339 \pm 31$ & $360 \pm 47$ \\
\hline $\begin{array}{c}\text { Fat intake } \\
\text { (g/day) }\end{array}$ & $97 \pm 10$ & $115 \pm 14$ & $126 \pm 18$ & $100 \pm 7$ & $98 \pm 9$ & $103 \pm 8$ & $107 \pm 12$ & $107 \pm 10$ & $99 \pm 12$ \\
\hline $\begin{array}{l}\text { Protein, } \% \text { total } \\
\text { caloric intake }\end{array}$ & $14 \pm 1$ & $16 \pm 1^{*}$ & $16 \pm 1^{*}$ & $16 \pm 1$ & $17 \pm 1^{*}$ & $17 \pm 1 *$ & $14 \pm 1$ & $19 \pm 1^{*}$ & $18 \pm 1^{*}$ \\
\hline $\begin{array}{l}\mathrm{CHO}, \% \text { total } \\
\text { caloric intake }\end{array}$ & $55 \pm 3$ & $56 \pm 4$ & $52 \pm 3$ & $51 \pm 2$ & $47 \pm 4$ & $51 \pm 2$ & $50 \pm 3$ & $46 \pm 2$ & $49 \pm 2$ \\
\hline $\begin{array}{c}\text { Fat, \% total } \\
\text { caloric intake }\end{array}$ & $30 \pm 2$ & $30 \pm 2$ & $32 \pm 2$ & $32 \pm 2$ & $30 \pm 2$ & $30 \pm 1$ & $33 \pm 2$ & $32 \pm 1$ & $31 \pm 1$ \\
\hline
\end{tabular}

Results are mean $\pm \mathrm{SE}$

*Significant main effect for time $(\mathrm{P}<0.05)$ 


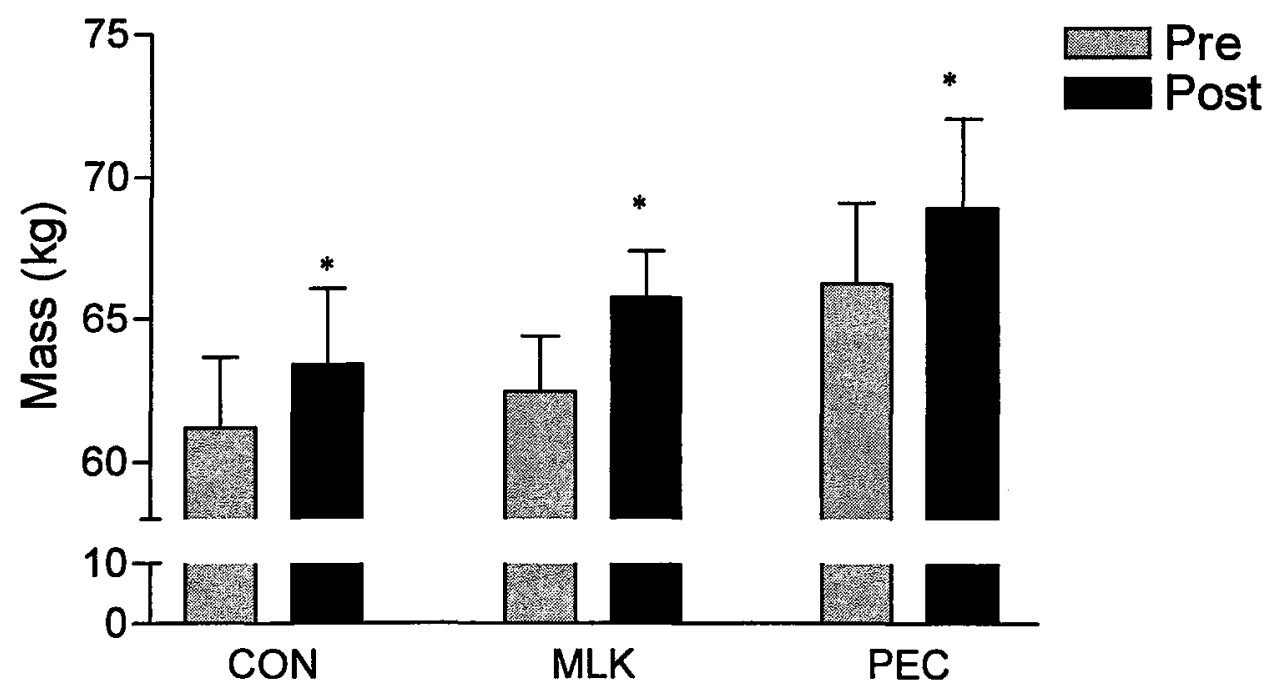

Figure 4. FBFM pre and post training (DXA). * Significant main effect for Time $(\mathrm{P}<0.05)$, time by group interaction $(\mathrm{P}=0.47)$.

\subsubsection{HISTOCHEMISTRY}

CON had a significantly larger type II fibre area than MLK and PEC before training $(\mathrm{P}<0.05)$. Following training there were large increases in type II fibre area MLK (22.2\%), PEC (12.2\%), and CON (9.5\%) (P<0.05) (see Figure 6, Table 5) but not for type I in all groups (see Figure 5, Table 5). No differences were observed for $\%$ fibre area before training. Significant increases occurred for Type IIa \% fibre area, while a significant decrease in Type IIx \% fibre area was present $(\mathrm{P}<0.05)$ (see Table 6). 
Table 5. Fibre area pre and post training

\begin{tabular}{|c|c|c|c|c|c|c|c|c|c|}
\hline & \multicolumn{3}{|c|}{$\mathrm{CON}$} & \multicolumn{3}{|c|}{ MLK } & \multicolumn{3}{|c|}{ PEC } \\
\hline & PRE & POST & $\% \Delta$ & PRE & POST & $\% \Delta$ & PRE & POST & $\% \Delta$ \\
\hline $\begin{array}{r}\text { Type I } \\
\text { Area }\left(\mu \mathrm{m}^{2}\right)\end{array}$ & $5424 \pm 267$ & $5611 \pm 286$ & $3.6 \pm 2.5$ & $4177 \pm 161$ & $4504 \pm 206$ & $8.4 \pm 5.3$ & $4620 \pm 360$ & $4889 \pm 357$ & $6.8 \pm 4.1$ \\
\hline $\begin{array}{l}\text { Type II } \\
\text { Area }\left(\mu \mathrm{m}^{2}\right)\end{array}$ & $6110 \pm 3459$ & $6674 \pm 355^{*}$ & $9.5 \pm 1.9$ & $5046 \pm 248$ & $6050 \pm 213^{*}$ & $22.2 \pm 7.2$ & $5366 \pm 142$ & $6016 \pm 227^{*}$ & $12.2 \pm 3.7$ \\
\hline
\end{tabular}

Results are Mean \pm SE

II Main effect for group ( $\mathrm{P}<0.05)$ (ANCOVA performed to account for these differences)

$*$ Main effect for time $(\mathrm{P}<0.05)$

Table 6. \% Fibre Area pre and post training

\begin{tabular}{|c|c|c|c|c|c|c|c|}
\hline & \multicolumn{2}{|c|}{ CON } & \multicolumn{2}{c|}{ MLK } & \multicolumn{2}{c|}{ PEC } & Average \\
\cline { 2 - 7 } & PRE & POST & PRE & POST & PRE & POST & PRE \\
\hline $\begin{array}{c}\text { Type I } \\
\text { Area } \\
\text { (\%) }\end{array}$ & $41 \pm 4$ & $42 \pm 2$ & $32 \pm 3$ & $33 \pm 4$ & $35 \pm 2$ & $37 \pm 3$ & $36 \pm 2$ \\
\hline $\begin{array}{c}\text { Type IIa } \\
\text { Area } \\
\text { (\%) }\end{array}$ & $35 \pm 4$ & $44 \pm 3^{*}$ & $44 \pm 3$ & $50 \pm 3^{*}$ & $42 \pm 4$ & $47 \pm 3^{*}$ & $40 \pm 2$ \\
\hline $\begin{array}{c}\text { Type IIb } \\
\text { Area } \\
(\%)\end{array}$ & $24 \pm 2$ & $16 \pm 3^{*}$ & $24 \pm 3$ & $16 \pm 2^{*}$ & $23 \pm 3$ & $16 \pm 2^{*}$ & $24 \pm 1$ \\
\hline
\end{tabular}

Results are Mean \pm SE

* Significant main effect for time $(\mathrm{P}<0.05)$ 


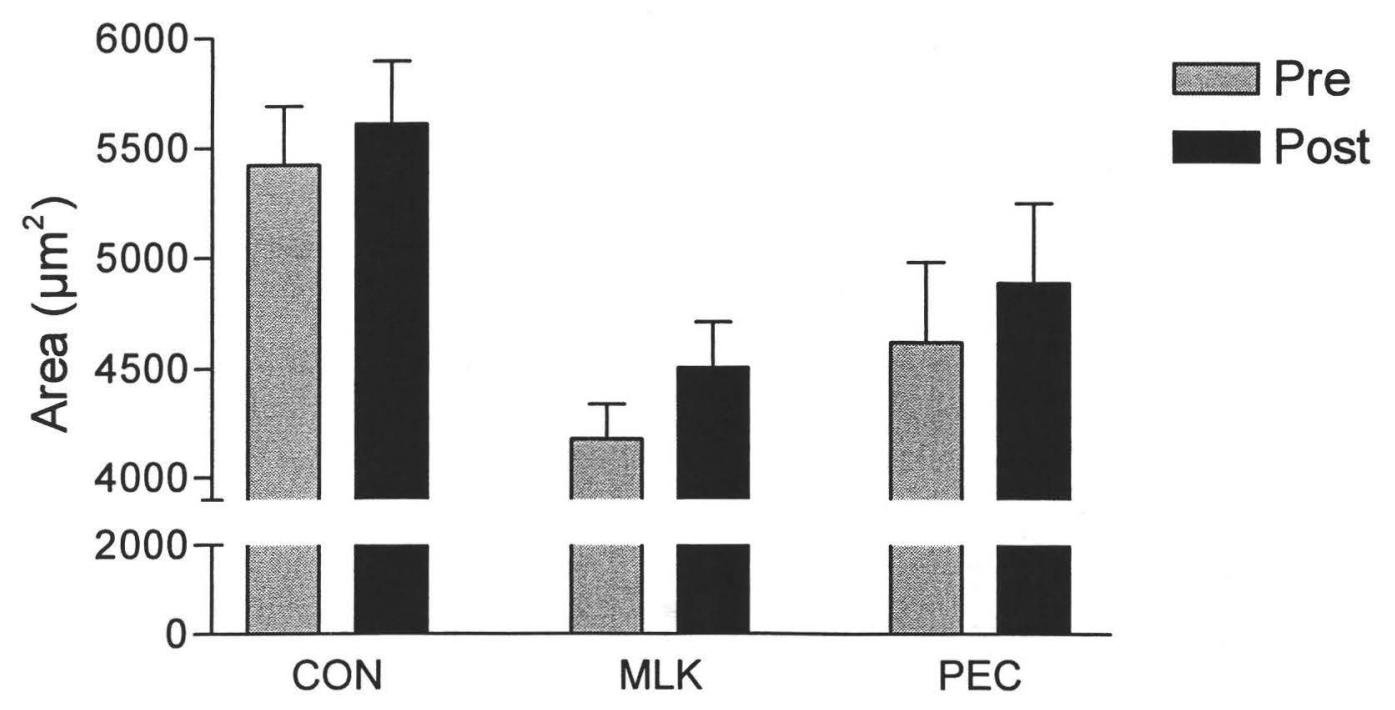

Figure 5. Type I fibre area pre and post training

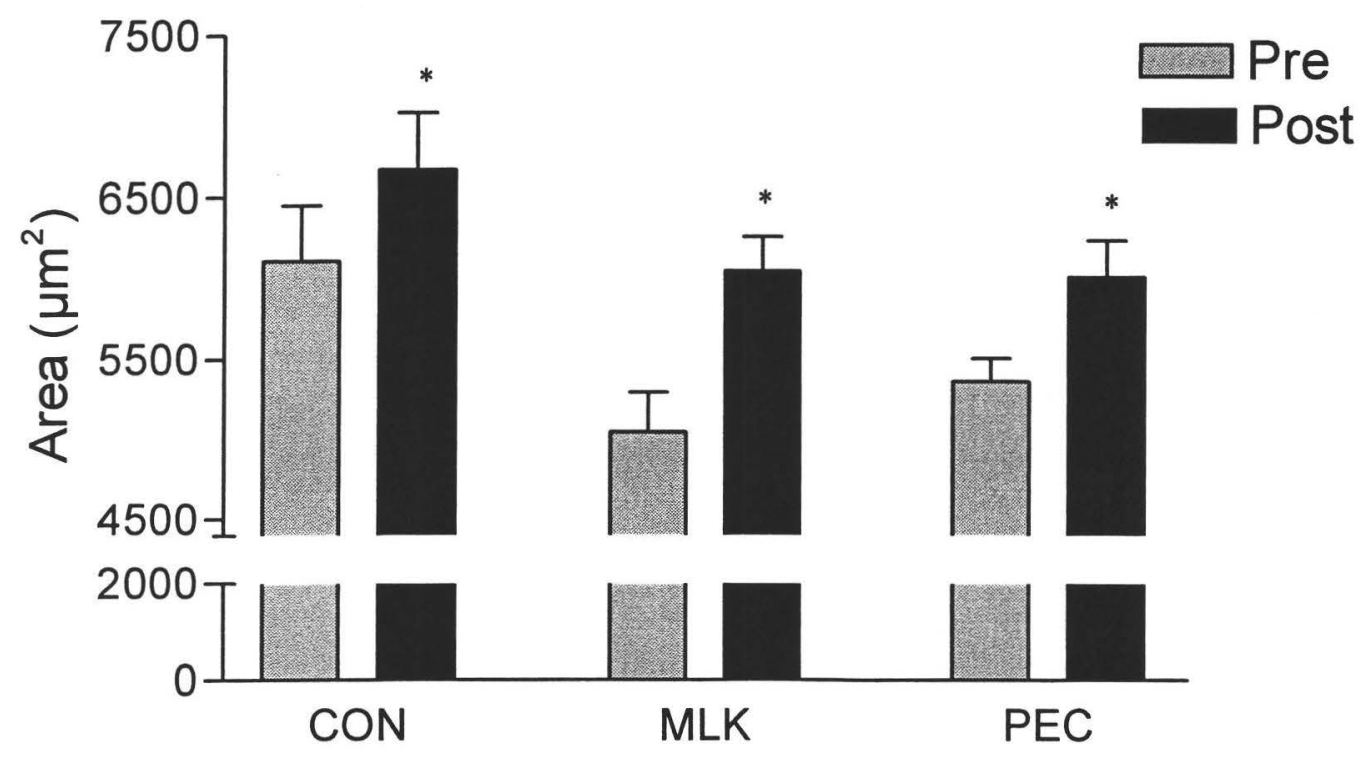

Figure 6. Type II fibre area pre and post training. * Main effect for Time $(\mathrm{P}<0.05)$, group by time interaction $(\mathrm{P}=0.18)$ 


\subsubsection{STRENGTH MEASUREMENTS}

No differences were present in IRM strength before training. All strength measurements increased significantly post training $(\mathrm{P}<0.05)$ and no group differences were present (see Table 7, 8 and 9). 
Table 7. 1RM (pushing exercises ) strength pre and post training

\begin{tabular}{|c|c|c|c|c|c|c|c|c|c|}
\hline & \multicolumn{3}{|c|}{ CON } & \multicolumn{3}{|c|}{ MLK } & \multicolumn{3}{|c|}{ PEC } \\
\hline & PRE & POST & $\% \Delta$ & PRE & POST & $\% \Delta$ & PRE & POST & $\% \Delta$ \\
\hline $\begin{array}{l}\text { Shoulder } \\
\text { Press (kg) }\end{array}$ & $53 \pm 6.3$ & $74 \pm 8.6^{*}$ & 38.4 & $69 \pm 3.9$ & $90 \pm 3.7^{*}$ & 29.2 & $64 \pm 4.7$ & $90 \pm 7.1^{*}$ & 39.8 \\
\hline $\begin{array}{c}\text { Bench Press } \\
\text { (kg) }\end{array}$ & $63 \pm 5.9$ & $104 \pm 7.4^{*}$ & 65.0 & $75 \pm 4.6$ & $111 \pm 4.4^{*}$ & 48.8 & $70 \pm 5.5$ & $107 \pm 7.1^{*}$ & 52.3 \\
\hline $\begin{array}{c}\text { Vertical } \\
\text { Bench Press } \\
(\mathrm{kg})\end{array}$ & $74 \pm 6.7$ & $129 \pm 10.0^{*}$ & 72.6 & $86 \pm 4.5$ & $134 \pm 7.0^{*}$ & 55.3 & $85 \pm 7.9$ & $131 \pm 11.3^{*}$ & 53.3 \\
\hline $\begin{array}{c}\text { Triceps Press } \\
\text { Down (kg) }\end{array}$ & $40 \pm 2.5$ & $58 \pm 2.8^{*}$ & 46.4 & $48 \pm 3.5$ & $65 \pm 2.9^{*}$ & 33.3 & $40 \pm 3.4$ & $65 \pm 3.3^{*}$ & 61.2 \\
\hline $\begin{array}{c}\text { Chest Flys } \\
\text { (kg) }\end{array}$ & $76 \pm 7.2$ & $120 \pm 9.0^{*}$ & 56.6 & $87 \pm 5.2$ & $141 \pm 11.5^{*}$ & 61.6 & $87 \pm 5.7$ & $135 \pm 9.9^{*}$ & 55.3 \\
\hline
\end{tabular}

Results are Mean \pm SE

*Significant main effect for time $(\mathrm{P}<0.05)$ 
Table 8. 1RM (pulling exercises ) strength pre and post training

\begin{tabular}{|c|c|c|c|c|c|c|c|c|c|}
\hline & \multicolumn{3}{|c|}{ CON } & \multicolumn{3}{|c|}{ MLK } & \multicolumn{3}{|c|}{ PEC } \\
\hline & PRE & POST & $\% \Delta$ & PRE & POST & $\% \Delta$ & PRE & POST & $\% \Delta$ \\
\hline $\begin{array}{l}\text { Lateral Pull } \\
\text { Down (kg) }\end{array}$ & $62 \pm 3.2$ & $82 \pm 4.4^{*}$ & 32.2 & $69 \pm 3.0$ & $89 \pm 3.8^{*}$ & 29.5 & $65 \pm 4.5$ & $85 \pm 4.5 *$ & 31.8 \\
\hline $\begin{array}{c}\text { Wide Row } \\
\text { (kg) }\end{array}$ & $59 \pm 4.4$ & $83 \pm 4.8^{*}$ & 40.0 & $67 \pm 2.8$ & $94 \pm 3.4^{*}$ & 40.5 & $65 \pm 6.5$ & $94 \pm 5.6^{*}$ & 44.8 \\
\hline $\begin{array}{l}\text { Narrow Row } \\
\text { (kg) }\end{array}$ & $62 \pm 4.7$ & $85 \pm 4.5^{*}$ & 37.5 & $68 \pm 2.8$ & $96 \pm 3.4^{*}$ & 40.7 & $68 \pm 6.0$ & $94 \pm 5.2^{*}$ & 38.9 \\
\hline $\begin{array}{l}\text { Biceps Curl } \\
\text { (kg) }\end{array}$ & $38 \pm 4.5$ & $70 \pm 5.6^{*}$ & 81.4 & $50 \pm 3.3$ & $76 \pm 4.4^{*}$ & 51.7 & $52 \pm 4.3$ & $74 \pm 3.7^{*}$ & 42.5 \\
\hline $\begin{array}{c}\text { Rear Flys } \\
\text { (kg) }\end{array}$ & $54 \pm 3.0$ & $81 \pm 4.5^{*}$ & 49.1 & $64 \pm 3.7$ & $93 \pm 5.1^{*}$ & 45.4 & $66 \pm 5.7$ & $93 \pm 5.8^{*}$ & 42.0 \\
\hline
\end{tabular}

Results are Mean $\pm \mathrm{SE}$

*Significant main effect for time $(\mathrm{P}<0.05)$

Table 9. 1RM (leg exercises ) strength pre and post training

\begin{tabular}{|c|c|c|c|c|c|c|c|c|c|}
\hline & \multicolumn{3}{|c|}{ CON } & \multicolumn{3}{|c|}{ MLK } & \multicolumn{3}{|c|}{ PEC } \\
\hline & PRE & POST & $\% \Delta$ & PRE & POST & $\% \Delta$ & $\overline{\text { PRE }}$ & POST & $\% \Delta$ \\
\hline $\begin{array}{l}\text { Leg Press } \\
\text { (kg) }\end{array}$ & $208 \pm 83.3$ & $342 \pm 47.0^{*}$ & 63.9 & $183 \pm 15.9$ & $368 \pm 23.9 *$ & 100.4 & $237 \pm 22.8$ & $477 \pm 48.7^{*}$ & 101.4 \\
\hline Leg Curl (kg) & $70 \pm 3.9$ & $106 \pm 6.2^{*}$ & 50.8 & $70 \pm 6.1$ & $108 \pm 5.9^{*}$ & 53.8 & $83 \pm 5.1$ & $117 \pm 7.5^{*}$ & 41.3 \\
\hline $\begin{array}{c}\text { Leg } \\
\text { Extension } \\
\text { (kg) }\end{array}$ & $103 \pm 7.0$ & $151 \pm 16.6^{*}$ & 45.8 & $106 \pm 4.9$ & $154 \pm 5.8^{*}$ & 45.5 & $123 \pm 5.9$ & $186 \pm 9.2^{*}$ & 50.7 \\
\hline
\end{tabular}

Results are Mean $\pm \mathrm{SE}$

*Significant main effect for time $(\mathrm{P}<0.05)$ 


\subsubsection{GLUCOSE AND INSULIN RESPONSE TO EXERCISE AND SUPPLEMENT CONSUMPTION}

Glucose concentrations were significantly higher at rest in the MLK group $(\mathrm{P}<0.05)$, but this difference was no longer present post-exercise. A significant time by group interaction was present $(\mathrm{P}<0.01)$ and Tukey Post-hoc analysis revealed the following: (i) CON glucose concentrations were significantly higher at 30 -min postexercise than MLK and PEC ( $\mathrm{P}<0.05$ ); (ii) Glucose concentrations were elevated above post-exercise concentrations at the 30 -min time point in CON group only $(\mathrm{P}<0.05)$; (iii) Glucose concentrations remained constant throughout the sampling period for both the MLK and PEC groups (see Figure 7).

Insulin concentrations between groups were not different post-exercise. A significant time by group interaction was present $(\mathrm{P}<0.01)$ and Tukey Post-hoc analysis revealed the following: (i) CON insulin concentrations were significantly higher at 30,60 and 120-min post-exercise than MLK $(\mathrm{P}<0.05)$ and at the 60 and 120-min post-exercise for the PEC group $(\mathrm{P}<0.05)$; (ii) Insulin concentrations were significantly elevated at the 30-min time point above post-exercise concentrations in all groups $(\mathrm{P}<0.05)$; (3) conversely at 60 and 120-min insulin concentrations were significantly elevated above post-exercise concentrations in CON only $(\mathrm{P}<0.05)$ (see figure 8). 


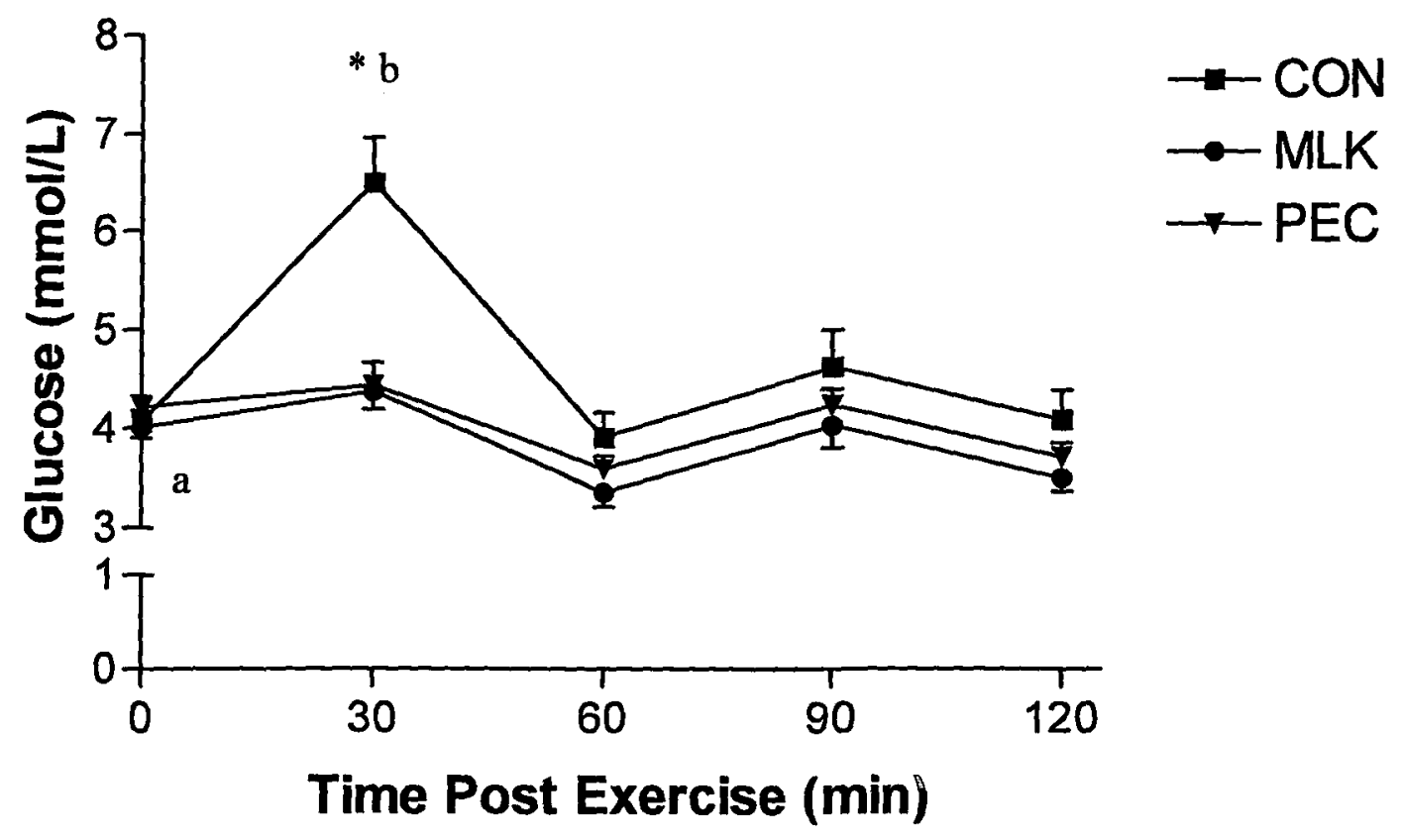

Figure 7. Blood glucose response to leg exercise and supplement consumption. Results are Mean \pm SE, b Significantly different from a $(\mathrm{P}<0.05)$, ${ }^{*}$ Significantly higher than MLK and $\mathrm{PEC}$ at same time point $(\mathrm{P}<0.05)$ 


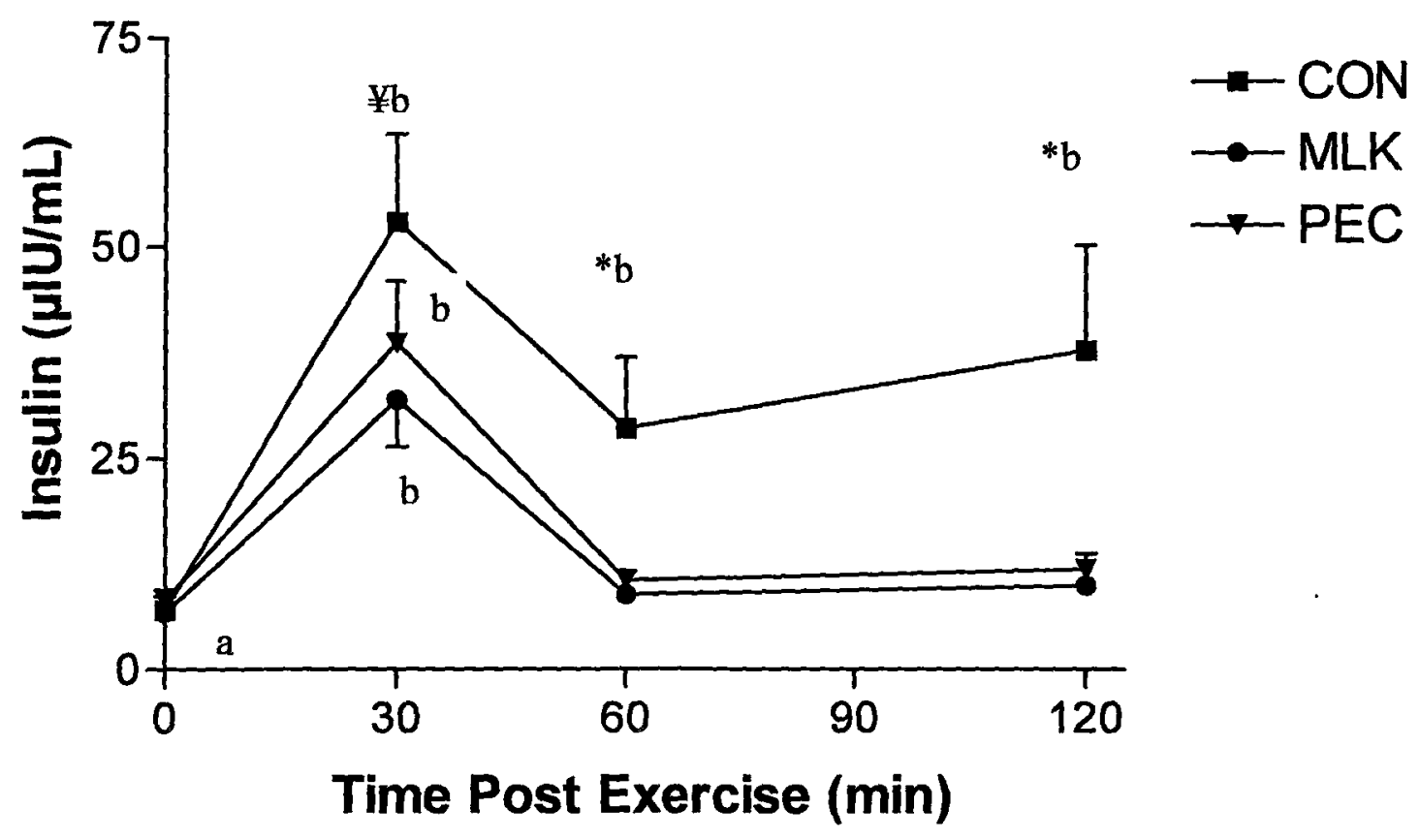

Figure 8. Blood insulin response to leg exercise and supplement consumption. Results are Mean $\pm \mathrm{SE}, b$ Significantly different from $\mathrm{a}(\mathrm{P}<0.05)$, * Significantly higher than MLK and PEC at same time point $(\mathrm{P}<0.05)$ YSignificantly higher that MLK at same time point $(\mathrm{P}<0.05)$

\subsubsection{CORRELATIONAL ANALYSES}

Lean mass gain did not correlate with either absolute or relative protein intake, or absolute caloric intake $(\mathrm{P}>0.05)$. Lean mass gain was significantly correlated with leg press strength gains $(\mathrm{P}<0.05)$ but not with bench press strength gains $(\mathrm{P}>0.05)$. 


\subsection{DISCUSSION}

The major novel findings of the present study were that intact dietary proteins are an effective stimulus for skeletal muscle accretion and promote hypertrophy of large magnitude, when consumed immediately post-exercise, and carbohydrate consumption alone is adequate to support hypertrophy when sufficient protein is consumed as part of a balanced diet. Fat and bone-free mass increased over the 12 week training program in all groups and the magnitudes of the increases in FBFM observed in this study were large; the MLK group gained $3.2 \pm 0.6 \mathrm{~kg}$, PEC $2.7 \pm 0.6 \mathrm{~kg}$, and CON $2.2 \pm 0.6 \mathrm{~kg}$. To our knowledge, this is the first study to utilize intact dietary proteins as a post-exercise supplement in conjunction with a chronic resistance training program. In comparison to the lean mass gains observed in studies of similar, or slightly shorter duration using amino acids or hydrolyzed, isolated protein fractions, our lean mass gains were similar $(20,72)$. This implies that intact dietary proteins are as effective as amino acids or isolated protein fractions at promoting skeletal muscle hypertrophy. Data from Wilkinson et al. (92) support this contention: these investigators observed that intact milk and soy proteins were an effective stimulus for increased muscle protein synthesis following an acute bout of resistance exercise, and that the magnitude of the increase in synthesis rates were similar to those of previous work that provided amino acids post-exercise, when discrepancies in blood flow were accounted for $(11,84,85,87)$. Therefore, intact dietary proteins are an effective stimulus for muscle protein synthesis that promote skeletal muscle accretion to the same degree as amino acids or isolated protein fractions. 
The amount of FBFM gained by the MLK group was $3.2 \pm 0.6 \mathrm{~kg}(5.5 \%)$, by the PEC group $2.7 \pm 0.6 \mathrm{~kg}(4.0 \%)$, and by the CON group $2.2 \pm 0.6 \mathrm{~kg}(3.6 \%)$ and there was no difference in gains between the groups $(\mathrm{P}=0.47)$. However, there was a notable trend in type II muscle fibre area $(\mathrm{P}=0.18)$, which reflected a similar pattern of change between the groups $\left(\mathrm{MLK}=1004 \pm 249 \mu \mathrm{m}^{2}(22 \%), \mathrm{PEC}=650 \pm 192 \mu \mathrm{m}^{2}(12 \%), \mathrm{CON}=565 \pm\right.$ $\left.120 \mathrm{\mu m}^{2}(9.5 \%)\right)$. It is difficult to argue, based on the P value for the FBFM interaction $(\mathrm{P}=0.47)$, that we have made a type 2 statistical error. The data from the type II fibre area revealed a stronger trend $(\mathrm{P}=0.18$ for a group by time interaction $)$ that indicated a greater hypertrophic gain in the MLK group. A post-hoc power analysis revealed that with alpha set at 0.05 and $\beta$ at 0.7 we could detect a significant difference in type II fibre area between MLK and CON with 4 more subjects per group and between MLK and PEC with 7 more subjects per group. Unfortunately, the acute post-exercise increase in protein consumption in the PEC and MLK group versus the CON group may have been obscured by the overall increase in daily protein intake in all groups. In a recently published study that compared the effect of a protein containing supplement to a carbohydrate only supplement on lean mass gains over a ten week training period, although not significant, greater lean mass gains were seen in the protein-only versus the carbohydrate-only group $(\mathrm{P}=0.077)(20)$. An acute study by Miller et al also provides support to our assertion; they observed that a drink containing both amino acids and carbohydrate significantly elevated net muscle protein synthesis rates following a resistance exercise bout, whereas a drink containing only carbohydrate did not significantly elevate net protein synthesis rates (51). Over a twelve week period these acute differences could translate into larger 
accretion of skeletal muscle in a group consuming a mixed carbohydrate protein drink compared to a group consuming solely carbohydrate. A study by Fouillet et al. (28) comparing milk and soy proteins directly also lends support to our theory. They observed that protein synthesis efficiencies were significantly greater in the peripheral area following milk protein ingestion compared to soy proteins. This suggests that longitudinally within our study, the MLK group would accrue more skeletal muscle than the PEC group.

Strength increases over the 12 week training study were identical between groups. The only interaction present was between the pre and 4 week strength measurements for biceps curls, the CON group gained significantly greater strength. These strength gains can be attributed mainly to neuromuscular adaptations since it has been demonstrated that neural factors account for most of the strength improvements observed in early phases of resistance training $(53,76,77)$, and were not the result of larger hypertrophy resulting from the supplement that this group was consuming. Clearly the strength gains observed in this study were of large magnitude and highly significant, ranging from $29 \%$ to $101 \%$, and were among the highest reported for a study of this duration $(20,26)$ and were similar between groups. It is unlikely that a type 2 statistical error could explain these results because strength gains were greater in CON for 4 exercises, MLK for 2, PEC for 4, and there were equivalent increases in the MLK and PEC groups for 1 exercise, and in all groups for 2 exercises. Thus, it appears that the differing post-exercise supplements had no effect on strength gain over the 12 week training period. 
Dietary analysis revealed that all groups increased protein ingestion during the training program. This was expected for both the MLK and PEC groups since they were receiving protein in their post-exercise drinks, however the CON group also increased protein consumption even though their post-exercise drinks contained no protein. To our knowledge, this is the first documented case in which protein consumption increased to such a degree during a resistance training program in a group whose supplement contained no additional protein $(72,82)$. One study has found that rats enhance protein selection in response to a protein deprivation period which could explain the response observed within the present study (10). One could also hypothesize that the human body is homeostatic and chooses an optimal protein intake. No other differences were present in macronutrient consumption as well as total energy intake. Protein consumption during the training program was high, between 1.4 and $1.8 \mathrm{~g} / \mathrm{kg} / \mathrm{d}$ for all groups which is within the range recommended by $\mathrm{ACSM} / \mathrm{ADA} / \mathrm{DC}$ position stand (56). This amount of protein would by all estimates be adequate to support protein requirements during a resistance training program $(45,80,81)$, and between group differences would not influence the degree of hypertrophy in any group in this study. Participants were required to refrain from consumption of any food or beverage for a 2-h period prior to each resistance exercise session and only consumed their supplement during the 2 -h post-exercise period, and these stringent guidelines could have affected participants eating habits. In a study of similar design no differences were observed in dietary intakes pre to post training even though participants were receiving a protein supplement equivalent to $0.13 \pm 0.01 \mathrm{~g}$ protein $/ \mathrm{kg}$ body wt (26). In the present study training times were scheduled so that they 
would not interfere with regular eating habits but if one assumes that training sessions took approximately $1-\mathrm{h}$, there was a $5 \mathrm{~h}$ time frame where participants consumed only $340 \mathrm{kcals}$ in the form of the supplements that were provided. This could have accounted for the lack of increase in overall energy consumption.

Glucose and insulin responses to a resistance exercise bout and supplement consumption were significantly higher in the CON group. This was expected considering that the CON group received solely carbohydrate post-exercise. Both the MLK and the PEC groups displayed significant elevations in blood insulin concentrations at the $30 \mathrm{~min}$ post-exercise time point, and at no other time point. This rise in insulin is important for supporting the increase in protein synthesis when amino acids are provided, and also decreasing protein breakdown following resistance exercise $(9,30)$. The combination of both these effects would create an environment favoring the accretion of skeletal muscle. That each group showed significant increases in insulin all drinks would have created a favourable environment for muscle hypertrophy; however, a rise in muscle protein synthesis is not observed when exogenous amino acids are not provided post-exercise $(9$, $12,70)$. Hence the lack of amino acids in the CON drink would have blunted the protein synthetic response post-exercise when compared to the MLK and PEC groups due to the lack of exogenous amino acids needed to induce the rise in protein synthesis (9), which would also decrease intracellular amino acid concentrations. Statistically, the CON group gained the same amount of FBFM as the MLK and PEC groups. Acute studies have shown that the provision of amino acids post-exercise are essential in shifting protein balance (i.e., synthesis minus breakdown) from negative to positive and promoting the 
accretion of skeletal muscle $(20,67,84,85,87)$. Roy and colleagues (70) observed that post-exercise consumption of a glucose drink significantly decreased protein breakdown (assessed by 3-methylhistidine excretion) and urinary urea nitrogen excretion, and did not significantly increase muscle protein FSR, resulting in a more positive protein balance due, the authors hypothesized, to the elevated concentrations of insulin they observed. Borsheim and colleagues (12) also observed an improved net muscle protein balance following carbohydrate consumption and this improvement was due primarily to a progressive decrease in muscle protein breakdown. They also remarked that the effect of carbohydrate ingestion was minor and delayed compared with the previously reported effect of ingestion of amino acids (12). It is evident, however, that the effect of carbohydrate ingestion on synthesis and breakdown rates may be a delayed effect, when compared to amino acids. The phenylalanine net balance observed in the previous study was only significantly improved at the 3 -h post-exercise time point, and unfortunately, analysis did not extend beyond this point (12). It is possible that the true effect was missed and occurred beyond the 3-h point. Similarly, a study by Miller et al. (51) observed a similar effect where net phenylalanine uptake continuously rose over the 3-h post-exercise time point in a group who consumed only carbohydrate post-exercise. Consequently, the true effect of carbohydrate ingestion post-exercise may take over 3-h to reach its full magnitude. In the present study it is likely that individuals would have consumed a protein-containing meal at the 2 -h time point post-exercise when diet restrictions were lifted. The CON group still had elevated insulin concentrations at the 2$\mathrm{h}$ time point creating an optimal environment for protein accretion, as amino acids had 
now been consumed. Data from Phillips and colleagues has established that protein synthesis rates are elevated for up to $48 \mathrm{~h}$ following an acute bout of resistance exercise (59); one would assume that any protein consumed over this period would allow for a more positive balance and increase skeletal muscle accretion. This could also influence the gains observed in both the MLK and PEC groups as they were consuming a regular mixed diet throughout the training program that contained protein from various sources.

The gains in FBFM and type II fibre area observed in the CON group also highlight the fact that protein consumption during the 2 -h post-exercise period is not essential for hypertrophy and strength gains to occur in young individuals. A landmark study by Esmarck et al (26) found that in elderly subjects, a lack of protein consumption during the 2 -h post-exercise period blunted strength gains and eliminated hypertrophy. Methodological differences were present between the Esmarck study and the present one, such as during the post-exercise period the control group (P2) received a drink containing no calories, whereas the CON group in the present study received carbohydrate.

Although carbohydrate supplementation post-exercise does improve net balance postexercise, it does not allow for a positive muscle protein balance, even at the 3-h time point post-exercise (12), so it is unlikely that the carbohydrate given during the postexercise period can account for the large gains in muscle mass in the present study. Although an acute bout of resistance exercise elevates protein synthesis rates similarly in the young and the elderly $(35,97)$ and muscle protein anabolism can be stimulated by oral amino acids in the elderly as well as in the young $(88,89)$, it is likely that the duration, and possibly the magnitude of the elevation in net muscle protein balance is shorter in the 
elderly compared to younger individuals. There is no direct evidence for this theory, although indirect evidence for this is observed in the larger gains found within the present study compared to previous studies of similar duration in the elderly $(17,26)$ as well as in a study by Welle et al. (91) directly comparing the hypertrophic response of young and elderly subjects. The greater hypertrophy in young individuals is likely the result of a more sustained elevation of protein synthesis rates compared to older subjects. This could account for the differences observed between the present study, and the Esmarck study (26).

Peripheral and splanchnic metabolism of dietary nitrogen is different for soy and milk proteins (28); milk proteins stimulate uptake of amino acids to a larger degree following resistance exercise than soy proteins (92). Within the present study a sample size of 11 (PEC) and 12 (MLK) was not large enough to translate the acute differences in protein synthesis between milk (MLK) and soy (PEC) (92) into significant differences in chronic training induced FBFM and fiber area gains. There does not appear to be any difference in the amino acid composition of soy and milk. Analysis of the composition of both the soy and milk protein used within the present study revealed that amino acid composition of the two proteins were remarkably similar (see Appendix 10).

Furthermore several nitrogen balance studies have found that the overall quality of isolated soy proteins is equivalent to that of milk in adults since both can support similar $\mathrm{N}$ balance $(73,101)$. Therefore, intuitively one would expect that the gains in skeletal muscle would be quite similar between soy and milk. It would appear that the major difference between milk and soy proteins in stimulating protein synthesis is their 
digestion rate (100). Several studies have highlighted these differences and have found that soy acts like a "fast" protein and milk a "slow" protein $(14,23,28)$. Soy is associated with a faster transfer of dietary $\mathrm{N}$ into urea and a higher level of incorporation into the serum protein pool (14).

Alternatively, Mariotti et al. (50) have found that the addition of carbohydrate (sucrose) to soy protein allows it to act more like a slow protein, resulting in a marked delay of gastric emptying versus a soy protein only meal. The effect of carbohydrate could have had a large influence within the present study considering that the soy drink contained carbohydrate to maintain energy equivalency, and could have allowed the soy to act more like a slow protein, possibly negating the differences in digestion between soy and milk. Prior research from our lab established a greater uptake of amino acids following milk ingestion compared to soy ingestion with the same drink composition as the present study (92). The largest differences, although not statistically significant, were at the 2 and 3-h time points post-exercise following consumption of a single drink (92). Within the present study a second drink was consumed 1-h post-exercise, a factor that can also affect post-prandial kinetics of fast proteins. Repeated whey protein ingestion caused a shift in post-prandial kinetics of this protein from fast to slow (21) and displayed a better leucine balance over a $7 \mathrm{~h}$ period compared to a single dose. Within the present study the repeated ingestion of the soy protein drink could also have caused it to act more like a slow protein than a fast protein. It should also be mentioned that the two hour postexercise time frame may have been too short a duration for differences between soy and milk proteins to be present. Most studies examining the differences between slow and 
fast proteins examine postprandial kinetics for up to $7 \mathrm{~h}(14,21,23,50)$. Since it is likely that participants in the present study consumed a meal immediately following the diet restriction period post-exercise, postprandial kinetics of the soy and milk proteins could have been affected.

Correlational analyses were performed to assess the relationship between dietary intakes and gains in FBFM. Absolute and relative protein intakes were not correlated with FBFM gains $(\mathrm{P}>0.05)$ lending evidence to the theory that once minimum protein requirements are met, further protein consumption does not increase lean mass (72). A third correlation was performed between FBFM gains and absolute caloric intake and again no significant interaction was present $(\mathrm{P}>0.05)$. A recently published article by Rozenik and colleagues (72) had hypothesized that once protein requirements are met, overall energy consumption is the largest determinant of lean mass gain while resistance training. It would appear from the results of the present study that this is not the case. Leg press strength gains were significantly correlated with FBFM gains $(\mathrm{P}<0.05)$, whereas bench press strength gains were not. It is surprising that one strength measure would be correlated with FBFM gains and another would not, the reason for this is unclear. 


\subsection{CONCLUSION}

Strength and lean mass gains observed within this study were of large magnitude, and illustrate the fact that designer supplements such as amino acids or isolated protein fractions are not needed to induce large gains in muscle mass while resistance training. In reality intact dietary proteins are more than sufficient to maximize skeletal muscle accretion while resistance training. Our results also indicate that simply consuming carbohydrate post-exercise is a sufficient stimulus to induce hypertrophy when adequate protein is being consumed as part of a balanced diet. It also appears that immediate consumption of protein during the $2-\mathrm{h}$ post-exercise period is not essential in younger subjects illustrating that differences exist between young and elderly populations with respect to protein consumption during the 2 -h post-exercise period. Our results also question the application of the many acute studies to actual longitudinal results. Acute studies have shown that muscle protein net balance does not become positive when only carbohydrate is ingested post-exercise; they have stated that the effect of carbohydrate ingestion post-exercise on muscle net balance is "minor" compared to that of amino acids (12). These large differences between carbohydrate and amino acids observed in acute studies do not translate into significant differences in hypertrophy. Past research has illustrated the importance of protein consumption post-exercise $(8,11,84,85,87)$ as well as differences between milk and soy proteins $(14,28)$ which did not convert into significant differences in hypertrophy over a 12 week resistance training program between the various groups within the present study. This calls into question the 
generalizability of some acute studies into long term effects as it appears that the large differences observed in acute protocols are largely diluted longitudinally. Future training studies basing their sample size calculations on results from acute studies should use trepidation when doing so, and increase sample sizes in order to account for these shortcomings. Differences between soy and milk protein sources, if present, are minute and these results illustrate the fact that as long as adequate protein is ingested within the diet, that additional supplements are not needed.

Future studies examining differences between soy and milk should attempt to use soy and milk proteins only, without carbohydrate present so that the true differences between the proteins can be examined without interference from carbohydrate. Stricter diet guidelines should also be implemented during the post-exercise period to allow the post-exercise drinks to have their full effect without interference from additional food sources. In addition the results from the present study illustrate the inherent differences between acute and longitudinal studies. Researchers must attempt to replicate some of the results observed in acute studies with longer term experiments in order to confirm the results they have obtained acutely. 


\section{REFERENCES}

1. Bennet WM, Connacher AA, Scrimgeour CM, Smith K, Rennie MJ. 1989. Increase in anterior tibialis muscle protein synthesis in healthy man during mixed amino acid infusion: studies of incorporation of $\left[1-{ }^{13} \mathrm{C}\right]$ leucine. Clin. Sci. 76:447-54

2. Bohe, J, Low JF, Wolfe RR, and Rennie MJ. 2001. Latency and duration of stimulation of human muscle protein synthesis during continuous infusion of amino acids. J Physiol 532: 575-579

3. Boirie Y, Dangin M, Gachon P, Vasson MP, Maubois JL, Beaufrere B. 1997. Slow and fast dietary proteins differently modulate postproandial protein accretion. Proc Natl Acad Sci. 94:14930-14935

4. Biolo G, Chinkes D, Zhang XJ, Wolfe RR. 1992. A new model to determine in vivo the relationship between amino acid transmembrane transport and protein kinetics in muscle. J. Parenter. Enter. Nutr. 16:305-15

5. Biolo G, Tesari $P$, Inchiostro S, Bruttomesso D, Fongher C, Sabadin L, Fratton MG, Valerio A, Tiengo A. 1992. Leucine and phenylalanine kinetics during mixed meal ingestion: a multiple tracer approach. Am J Physiol. 262: E455-E463

6. Biolo G, Fleming RYD, Wolfe RR. 1995. Physiologic hyperinsulinemia stimulates protein synthesis and enhances transport of selected amino acids in human skeletal muscle. J Clin Invest. 95:811-819

7. Biolo G, Maggi SP, Williams BD, Tipton KD, Wolfe RR. 1995. Increased rates of muscle protein-turnover and amino-acid-transport after resistance exercise in humans. Am. J. Physiol.-Endocrinol. Metab. 31:E514-20

8. Biolo G, Tipton KD, Klein S, Wolfe RR. 1997. An abundant supply of amino acids enhances the metabolic effect of exercise on muscle protein. Am. J. Physiol.

Endocrinol. Metab. 273:E122-29

9. Biolo G, Williams BD, Fleming RYD, Wolfe RR. 1999. Insulin action on muscle protein kinetics and amino acid transport during recovery after resistance exercise. Diabetes 48:949-57

10. Boghossian S, Nzang Nguema G, Jourdan D, Alliot J. 2002. Old as mature LOU/c/jall rats enhance protein selection in response to a protein deprivation. Experimental Gerontology. 37:1431-1440 
11. Borsheim E, Tipton KD, Wolf SE, Wolfe RR. 2002. Essential amino acids and muscle protein recovery from resistance exercise. Am J Physiol Endocrinol Metab. 283:E648657

12. Borsheim E, Cree MG, Tipton KD, Elliott TA, Aarsland A, Wolfe RR. 2004. Effect of carbohydrate intake on net muscle protein synthesis during recovery from resistance exercise. J Appl Physiol. 96:674-678

13. Bos C, Mahe S, Gaudichon C, Benamouzig R, Gaussere N, Leungo C, Ferriere F, Rautureau J, Tome D. 1999. Assessment of net postprandial protein utiliztion of $15 \mathrm{~N}$ labeled milk nitrogen in human subjects. $B J$ Nutr. 81:221-226

14. Bos C, Metges CC, Gaudichon C, Petzke KJ, Pueyo ME, Morens C, Everwand J, Benamouzig R, Tome D. 2003. Postprandial kinetics of dietary amino acids are the main determinat of their metabolism after soy or milk protein ingestion in humans. $J$ Nutr. 133:1308-1315

15. Brooke MH, Kaiser KK. 1970. Three "myosin adenosine triphosphatase" systems: the nature of their $\mathrm{pH}$ lability and sulfhydryl dependence. J Histochem Cytochem. 18:670672

16. Brown AB, McCartney N, Sale DG. 1990. Positive adaptations to weight-lifting training in the elderly. J. Appl. Physiol. 69: 1725-1733

17. Campbell WW, Barton Jr ML, Cyr-Campbell D, Davey SL, Beard JL, Parise G, Evans JE. 1999. Effects of an omnivorous diet compared with a lactoovovegetarian diet on resistance-training-induced changes in body composition and skeletal muscle in older men. Am J Clin Nutr. 70:1032-1039

18. Carraro F, Hartl WH, Stuart CA, Layman DK, Jahoor F, Wolfe RR. 1990. Whole body and plasma protein synthesis in exercise and recovery in human subjects. Am. J. Physiol. 258:E821-31

19. Chilibeck P, Calder A, Sale DG, Webber C. 1994. Reproducibility of dual-energy Xray absorptiometry. Can Assoc Radiol J. 45:297-302

20. Chromiak JA, Smedley B, Carpenter W, Brown R, Koh YS, Lamberth JG, Joe LA, Abadie BR, Altorfer G. 2004. Effect of a 10-Week strength training program and recovery drink on body composition, muscular strength and endurance, and anaerobic power and capacity. Nutrition. 20:420-427

21. Dangin M, Boirie Y, Garcia-Rodenas C, Gachon P, Fauquant J, Callier P, Ballevre O, Beaufrere B. 2001. The digestion rate of protein is an independent regulating factor of postprandial protein retention. Am J Physiol Endocrinol Metab. 280:E340-E348 
22. Dangin M, Guillet C, Garcia-Rodenas C, Gachon P, Bouteloup-Demange C, ReiffersMagnani K, Fauquant J, Balevre O, Beaufrere B. 2003. The rate of protein digestion affects protein gain differently during aging in humans. $J$ Physiol. 549.2:635-644

23. Deutz NEP, Bruins MJ, Soeters PB. 1998. Infusion of soy and casein protein meals affects interorgan amino acid metabolism and urea kinetics differently in pigs. $J$ Nutr. $128: 2435-2445$

24. Dohm GL, Kasperek GJ, Tapscott EB, Beecher GR. 1980. Effect of exercise on synthesis and degradation of muscle protein. Biochem. J. 188:255-62

25. Dohm GL, Tapscott EB, Barakat HA, Kasperek GL. 1982. Measurement of in vivo protein synthesis in rats during an exercise bout. Biochem. Med. 27:367-73

26. Esmarck B, Andersen JL, Olsen S, Richter EA, Mizuno M Kjaer M. 2001. Timing of postexercise protein intake is important for muscle hypertrophy with resistance training in elderly humans. J. Physiol. 535.1: 301-311

27. Farrell PA, Fedele MJ, Hernandez J, Fluckey JD, Miller JL III, et al.1999. Hypertrophy of skeletal muscle in diabetic rats in response to chronic resistance exercise. J. Appl. Physiol. 87:1075-82

28. Fouillet H, Mariotti F, Gaudichon C, Bos C, Tome D. 2002. Peripheral and splanchnic metabolism of dietary nitrogen are differently affected by the protein source in humans asa assessed by compartmental modeling. $J$ Nutr. 132:125-133

29. Frontera WR, Meridith CN, O'Reilly KP, Knuttgen HG, Evans WJ. 1988. Strength conditioning in older men: skeletal muscle hypertrophy and improved function. $J$. Appl. Physiol. 64, 1038-1044

30. Fluckey JD, Vary TC, Jefferson LS, Evans WJ, and Farrell PA. 1996. Insulin stimulation of protein synthesis in rat skeletal muscle following resistance exercise is maintained with advancing age. $J$ Gerontol Biol Sci 51A: B323-B330

31. Gaudichon C, Mahe S, Bebamouzig R, Luengo C, Fouillet H, Dare S, Van Oycke M, Ferriere F, Rautureau J, Tome D. 1999. Net postprandial utilization of [15N]-labeled milk protein nitrogen is influenced by diet composition in humans. $J$ Nutr. 129:890895

32. Gibala MJ. 2000. Nutritional supplementation and resistance exercise: What is the evidence for enhanced skeletal muscle hypertrophy? Can J Appl Physiol. 25:524-535 
33. Giordano M, Castellino P, DeFronzo RA. 1996. Differential responsiveness of protein synthesis and degradation to amino acid availability in humans. Diabetes 45:393-399

34. Greiwe JS, Kwon G, McDaniel ML, Semenkovich CF. 2001. Leucine and insulin activate p70 S6 kinase through different pathways in human skeletal muscle. Am J Physiol Endocrinol Metab. 281:E466-E471

35. Hasten DL, Pak-Loduca J, Obert KA, Yarasheski KE. 2000. Resistance exercise acutely increases MHC and mixed muscle protein synthesis rates in 78-84 and 23-32 yr olds. Am J Physio Endocrinol Metab. 278:E620-626

36. Haub MD, Wells AM, Tarnopolsky MA, Campbell WW. 2002. Effect of protein source on resistive-training-induced changes in body composition and muscle size in older men. Am J Clin Nutr. 76:511-517

37. Houston ME, Froese EA, Valeriote StP, Green HJ. 1983. Muscle performance, morphology and metabolic capacity during strength training and detraining: a one leg model. Eur J Appl Physiol Occup Physiol. 51:25-35

38. Istfan N, Murray E, Janghorbani M, Young VR. 1983. An evaluation of the nutritional value of a soy protein concentrate in young adult men using the short-term $\mathrm{N}$-balance method. $J$ Nutr. 113:2516-2523

39. Jefferson, LS, Rannels DE, Munger BL, and Morgan HE. 1974. Insulin in the regulation of protein turnover in heart and skeletal muscle. Fed Proc 33: 1098-1104

40. Jones DA, Rutherford OM. 1987. Human muscle strength training: the effects of three different regimes and the nature of the resultant changes. J. Physiol. London 391:1-11

41. Karinch, AM, Kimball SR, Vary TC, and Jefferson LS. Regulation of eukaryotic initiation factor-2B activity in muscle of diabetic rats. Am J Physiol Endocrinol Metab 264: E101-E108, 1993

42. Kimball, SR, Vary TC, and Jefferson LS. 1994. Regulation of protein synthesis by insulin. Annu Rev Physiol 56: 321-348

43. Kimball SR, Jefferson LS. 2001. Regulation of protein synthesis by branched-chain amino acids. Curr Opin Clin Nutr Metab Care. 4:39-43

44. Kobayashi H, Borsheim E, Anthony TG, Traber DL, Badalamenti J, Kimball SR, Jefferson LS, Wolfe RR. 2003. Reduced amino acid availability inhibits muscle protein synthesis and decreases activity of initiation factor eIF2B. 284: E488-498 
45. Lemon PW, Tarnopolsky MA, MacDougall JD, Atkinson SA. 1992. protein requirements and muscle mass / strength changes during intensive training in novice bodybuilders. J Appl Physiol. 73:767

46. Lohrke B, Saggau E, Schadereit R, Beyer M, Bellman O, Kuhla S, Hagemeister H. 2001. Activation of skeletal muscle protein breakdown following consumption of soyabean protein in pigs. Br J Nutr. 85:447-457

47. Luthi JM, Howald H, Claasen H, Rosler K, Vock P, Hoppeler H. 1986. Structural changes in skeletal muscle tissue with heavy resistance exercise. Int. J. Sports Med. $7: 123-27$

48. MacDougall JD, Elder GCB, Sale DG, Moroz JR. 1980. Effects of strength training and immobilization on human muscle fibres. Eur J Appl Physiol Occup Physiol. 43:25-34

49. MacDougall JD, Gibala MJ, Tarnopolsky MA, MacDonald JR, Interisano SA, Yarasheski KE. 1995. The time course for elevated muscle protein synthesis following heavy resistance exercise. Can. J. Appl. Physiol. 20:480-86

50. Mariotti F, Sylvain M, Luengo C, Benamouzig R, Tome D. 2000. Postprandial modulation of dietary and whole-body nitrogen utilizatin by carbohydrates in humans. Am J Clin Nutr. 72:954-62

51. Miller SL, Tipton KD, Chinkes DL, Wolf SE, Wolfe RR. 2003. Independent and combined effects of amino acids and glucose after resistance exercise. Med Sci Sports Exerc. 35:449-455

52. Morens C, Bos C, Pueyo ME, Benamouzig R, Gaussere N, Luengo C, Tome D, Gaudichon C. 2003. Increasing habitual protein intake accentuates differences in postprandial dietary nitrogen utilization between protein sources in humans. $J$ Nutr. $133: 2733-2740$

53. Moritani T, DeVries HA. 1979. Neural factors versus gypertrophy in the time course of muscle strength gain. Am J Phys med. 58:115-130

54. Motil, KJ, Mathews DE, Dier DM, Burke JF, Munro HN, Young VR. 1981. Whole body leucine and lysine metabolism: response to dietary protein intake in young men. Am. J. Physiol. 240:E712-721

55. Mussini E, Colombo L, DePonte G, Calzi M, Marcucci F. 1985. Effect of swimming on protein degradation: 3-methylhistidine and creatinine excretion. Biochem. Med. $34: 373-75$ 
56. Nutrition and athletic performance: ACSM/ADA/DC Joint position statement. 2000. Med Sci Sport Exerc. 30:2130-2145

57. Pette D, Staron RS. 2000. Myosin isoforms, muscle fiber types, and transistions. Microsc Res Tech. 50:500-509

58. Pette D, Staron RS. 2001. Transition of muscle fiber phenotypic profiles. Histochem Cell Biol. 115:359-372

59. Phillips SM, Tipton KD, Aarsl A, Wolf SE, Wolfe RR. 1997. Mixed muscle protein synthesis and breakdown following resistance exercise in humans. Am. J. Physiol. Endocrinol. Metab. 273:E99-107

60. Phillips SM, Tipton KD, Ferrando AA, Wolfe RR. 1999. Resistance training reduces the acute exercise-induced increase in muscle protein turnover. Am. J. Physiol. 276:E118-24

61. Phillips SM, Parise G, Roy BD, Tipton KD, Wolfe RR, Tarnopolsky MA. 2002. Resistance training induced adaptations in skeletal muscle protein turnover in the fed state. Can. J. Physiol. Pharmacol. 80:1045-1053

62. Plante PD, Houston ME. 1984. Effects of concentric and eccentric exercise on protein catabolism in man. Int. J. Sports Med. 5:174-78

63. Plante RI, Houston ME. 1984. Exercise and protein catabolism in women. Ann. Nutr. Metab. 28:123-29

64. Price, GM, Halliday D, Pacy PJ, Quevedo MR, and Millward DJ. 1994. Nitrogen homeostasis in man: influence of protein intake on the amplitude of diurnal cycling of body nitrogen. Clin Sci (Colch) 86: 91-102

65. Raben A, Kiens B, Richter EA, Rasmussen LB, Svenstrup B, Micic S, Bennet P. 1992. Serum sex hormones and endurance performance after a lacto-ovo vegetarian and a mixed diet. Med Sci Sports Exerc. 24:1290-1297

66. Radha E, Bessman SP. 1983. Effect of exercise on protein degradation: 3methylhistidine and creatinine excretion. Biochem. Med. 29:96-100

67. Rasmussen, BB, Tipton KD, Miller SL, Wolf SE, and Wolfe RR. 2000. An oral essential amino acid-carbohydrate supplement enhances muscle protein anabolism after resistance exercise. J Appl Physiol 88: 386-392

68. Rennie MJ, Edwards RH, Krywawych S, Davies CT, Halliday D, et al.1981. Effect of exercise on protein turnover in man. Clin. Sci. 61:627-39 
69. Rennie MJ, Tipton KD, 2000. Protein and amino acid metabolism during and after exercise and the effects of nutrition. Annu. Rev. Nutr. 20:457-83

70. Roy BD, Tarnopolsky MA, MacDougall JD, Fowles J, Yarasheski KE. 1997. Effect of glucose supplement timing on protein metabolism after resistance exercise. J. Appl. Physiol. 82:1882-88

71. Roy BD, Fowles JR, Hill R, Tarnopolsky MA. 2000. Macronutrient intake and whole body protein metabolism following resistance exercise. Med Sci Sports Exerc. $32: 1412-1418$

72. Rozenek R, Ward P, Long S, Garhammer J. 2002. Effects of high-calorie supplements on body composition and muscular strength following resistance training. J Sports Med Phys Fitness. 42:340-347

73. Scrimshaw NS, Wayler AH, Murray E, Steike FH, Rand WM, Young VR. 1983. Nitrogen balance response in young men given one of two isolated soy proteins or milk proteins. $J$ Nutr. 113:2492-2497

74. Staron RS, Hikida RS, Hagerman FC, Dudley GA, Murray TF. 1984. Human skeletal muscle fiber type adaptability to various workloads. J Histochem Cytochem. 32:146152

75. Staron RS, Malicky ES, Leonardi MJ, Falkei JE, Hagerman FC, Dudley GA. 1990. Muscle hypertrophy and fast fiber type conversions in heavy resistance-trained women. Eur J Appl Physiol Occup Physiol. 60:71-79

76. Staron RS, Leonardi MJ, Karapondo DL, Malicky ES, Falkel JE, Hagerman FC, Hikida RS. 1991. Strength and skeletal muscle adaptations in heavy-resistance-trained women after detraining and retraining. J Appl Physiol 70: 631-40

77. Staron RS, Karapondo DL, Kraemer WJ, et al: 1994 Skeletal muscle adaptations during early phase of heavy-resistance training in men and women. $J$ Appl Physiol. 76: $1247-55$

78. Staron RS, Hagerman FC, Hikida RS, Murray TF, Hostler DP, Crill MT, Ragg KE, Toma K. 2000. Fiber type composition of the vastus lateralis muscle of young men and women. $J$ Histochem Cytochem. 48:623-629

79. Suzuki M, Doi T, Lee SJ, Okamura K, Shimizu S, Okano G, Sato Y, Shimomura Y, Fushiki T. 1999. Effect of meal timing after resistance exercise on hindlimb muscle mass and fat accumulation in trained rats. J. Nutr. Sci. Vitaminol. 45: 401-409 
80. Tarnopolsky MA, MacDougall JD, Atkinson SA. 1988. Influence of protein intake and training status on nitrogen balance and lean body mass. J Appl Physiol. 64:187

81. Tarnopolsky MA, Atkinson SA, MacDougall JD, Chesley A, Phillips SM, Schwarcz HP. 1992. Evaluation of protein requirements for trained strength athletes. $J$ Appl Physiol. 73:1986-1995

82. Tarnopolsky MA, Parise G, Yardley NJ, Ballantyne CS, Olatunji S, Phillips SM. 2001. Creatine-dextrose and protein-dextrose induce similar strength gains during training. Med Sci Sports Exerc. 33:2044-2052

83. Thorstensson A. 1977. Observations on strength training and detraining. Acta Physiol Scand. 100:491-493

84. Tipton KD, Borsheim E, Wolf SE, Sanford AP, Wolfe RR. 2003. Acute response of net muscle protein balance reflects $24 \mathrm{~h}$ balance after exercise and amino acid ingestion. Am. J. Physiol. Endocrinol. Metab. 264:E76-E89

85. Tipton KD, Ferrando AA, Phillips SM, Doyle D Jr,Wolfe RR. 1999. Postexercise net protein synthesis in human muscle from orally administered amino acids. Am. $J$. Physiol. 276:E628-34

86. Tipton KD, Ferrando AA, Williams BD, Wolfe RR. 1996. Muscle protein metabolism in female swimmers after a combination of resistance and endurance exercise. J. Appl. Physiol. 81:2034-38

87. Tipton, KD, Rasmussen BB, Miller SL, Wolf SE, Owens-Stovall SK, Petrini BE, and Wolfe RR. 2001.Timing of amino acid-carbohydrate ingestion alters anabolic response of muscle to resistance exercise. Am J Physiol Endocrinol Metab 281: E197E206

88. Volpi E, Ferrando AA, Yeckel CW, Tipton KD, Wolfe RR. 1998. Exogenous amino acids stimulate net muscle protein synthesis in the elderly. J Clin Invest. 101:20002007

89. Volpi E, Mittendorfer B, Wolf SE, Wolfe RR. 1999. Oral amino acids stimulate muscle protein anabolism in the elderly despite higher first-pass splanchnic extraction. Am J Physiol. 277:E513-520

90. Wahren J, Felig P, Hagenfeldt L. 1976. Effect of protein ingestion on splanchnic and leg metabolism in normal man and in patients with diabetes mellitus. J Clin Investig. $57: 987-999$ 
91. Welle S, Totterman S, Thornton C. 1996. Effect of age on muscle hypertrophy induced by resistance training. J Gerontol A Biol Sci Med Sci. 51:M270-275

92. Wilkinson SB, MacDonald JR, MacDonald MJ, Tarnopolsky MA, Phillips SM. 2004. Milk proteins promote greater net protein balance than soy proteins following resistance exercise. FASEB. 18:A854

93. Wolfe RR, Goodenough RD, Wolfe MH, Royle GT, Nadel ER. 1982. Isotopic analysis of leucine and urea metabolism in exercising humans. J Appl Physiol. $52: 458-466$

94. Wolfe RR. 2000. Protein supplements and exercise. Am J Clin Nutr. 72:551S-557S

95. Wolfe RR, Volpi E. 2001. Insulin and protein metabolism. In: Handbook of Physiology. Section 7 Volume 2, L. S. Jefferson and A. D. Cherrington (Eds.). New York: Oxford, 2001. pp 735-757

96. Yarasheski KE, Campbell JA, Smith K, Rennie MJ, Holloszy JO, Bier DM. 1992. Effect of growth hormone and resistance exercise on muscle growth in young men. Am. J. Physiol. 262:E261-67

97. Yarasheski KE, Zachwieja JJ, Bier DM. 1993. Acute effects of resistance exercise on muscle protein synthesis rate in young and elderly men and women. Am J Physiol. 265:E210-214

98. Yarasheski KE, Zachwieja JJ, Campbell JA, Bier DM. 1995. Effect of growthhormone and resistance exercise on muscle growth and strength in older men. Am.J. Physiol.-Endocrinol. Metab. 31:E268-76

99. Young VR, Wayler A, Garza C, Steinke FH, Murray E, Rand WM, Scrimshaw NS. 1984. A long-term metabolic balance study in young men to assess the nutritional quality of an isolated soy protein and beef proteins. Am J Clin Nutr. 39:8-15

100. Young VR. 1991. Soy protein in relation to human protein and amino acid nutrition. $J$ Am Diet Assoc. 91:828-835

101. Young VR, Pellett PL. 1994. Plant proteins in relation to human protein and amino acid nutrition. Am J Clin Nutr. 59(Suppl):1203S-1212S

102.Zhang XJ, Chinkes DL, Sakurai Y, Wolfe RR. 1996. An isotopic method for measurement of muscle protein fractional breakdown rate in vivo. Am. J. Physiol. 270:E759-67 
APPENDIX 1

DIET RECORD DATA, and ANOVA TABLES 
Diet Record Raw Data: Pre Training

\begin{tabular}{|c|c|c|c|c|c|c|c|c|c|c|c|c|}
\hline & Subject & Age & $W_{t}(\mathrm{~kg})$ & avg $\mathbf{k J}$ & avg kcal & kcal/kg & PRO & PRO/kg & $\mathrm{CHO}$ & $\mathrm{CHO} / \mathrm{kg}$ & FAT & FAT/kg \\
\hline \multirow[t]{11}{*}{ Group 1} & s1 & 18 & 51.8 & 10316.2 & 2468 & 47.64 & 88 & 1.70 & 349 & 6.74 & 85 & 1.64 \\
\hline & 52 & 19 & 100.0 & 16795.2 & 4018 & 40.18 & 96 & 0.96 & 687 & 6.87 & 106 & 1.06 \\
\hline & S3 & 22 & 84.6 & 18237.3 & 4363 & 51.57 & 114 & 1.35 & 550 & 6.50 & 151 & 1.78 \\
\hline & 54 & 22 & 77.7 & 11695.6 & 2798 & 36.01 & 83 & 1.07 & 389 & 5.01 & 103 & 1.33 \\
\hline & S5 & 20 & 82.1 & 8836.5 & 2114 & 25.75 & 90 & 1.10 & 312 & 3.80 & 57 & 0.69 \\
\hline & S6 & 32 & 81.0 & 13024.9 & 3116 & 38.47 & 102 & 1.26 & 451 & 5.57 & 106 & 1.31 \\
\hline & 57 & 31 & 75.6 & 13133.6 & 3142 & 41.56 & 129 & 1.71 & 459 & 6.07 & 102 & 1.35 \\
\hline & s9 & 21 & 75.5 & 7160.3 & 1713 & 22.69 & 84 & 1.11 & 144 & 1.91 & 88 & 1.17 \\
\hline & S10 & 21 & 99.5 & 10688.3 & 2557 & 25.70 & 106 & 1.07 & 431 & 4.33 & 45 & 0.45 \\
\hline & s11 & 22 & 75.1 & 18040.9 & 4316 & 57.47 & 135 & 1.80 & 544 & 7.24 & 147 & 1.96 \\
\hline & $\mathrm{S} 12$ & 22 & 67.2 & 8472.9 & 2027 & 30.16 & 83 & 1.24 & 255 & 3.79 & 78 & 1.16 \\
\hline \multirow[t]{12}{*}{ Group 2} & $\mathrm{~s} 13$ & 32 & 68.0 & 9831.4 & 2352 & 34.59 & 76 & 1.12 & 319 & 4.69 & 92 & 1.35 \\
\hline & s14 & 20 & 72.8 & 14567.3 & 3485 & 47.87 & 136 & 1.87 & 552 & 7.58 & 90 & 1.24 \\
\hline & S15 & 20 & 71.5 & 8999.5 & 2153 & 30.11 & 85 & 1.19 & 254 & 3.55 & 94 & 1.31 \\
\hline & S16 & 22 & 89.5 & 14813.9 & 3544 & 39.60 & 190 & 2.12 & 407 & 4.55 & 134 & 1.50 \\
\hline & S17 & 23 & 83.5 & 13292.4 & 3180 & 38.08 & 108 & 1.29 & 393 & 4.71 & 95 & 1.14 \\
\hline & $\mathrm{s} 18$ & 22 & 96.6 & 13325.8 & 3188 & 33.00 & 126 & 1.30 & 381 & 3.94 & 123 & 1.27 \\
\hline & $\mathrm{s} 19$ & 22 & 82.5 & 5889.6 & 1409 & 17.08 & 69 & 0.84 & 155 & 1.88 & 58 & 0.70 \\
\hline & $\mathbf{S 2 0}$ & 19 & 64.0 & 15185.9 & 3633 & 56.77 & 135 & 2.11 & 547 & 8.55 & 110 & 1.72 \\
\hline & $\mathbf{S 2 1}$ & 21 & 70.0 & 12209.8 & 2921 & 41.73 & 117 & 1.67 & 320 & 4.57 & 132 & 1.89 \\
\hline & $s 22$ & 23 & 92.8 & 12995.6 & 3109 & 33.50 & 104 & 1.12 & 371 & 4.00 & 112 & 1.21 \\
\hline & $\mathbf{s} 23$ & 21 & 82.0 & 10692.4 & 2558 & 31.20 & 93 & 1.13 & 313 & 3.82 & 79 & 0.96 \\
\hline & S24 & 32 & 90.5 & 13643.5 & 3264 & 36.07 & 139 & 1.54 & 505 & 5.58 & 83 & 0.92 \\
\hline \multirow[t]{11}{*}{ Group 3} & S25 & 19 & 70.0 & 12636.1 & 3023 & 43.19 & 117 & 1.67 & 414 & 5.91 & 107 & 1.53 \\
\hline & $\mathbf{S 2 6}$ & 19 & 99.0 & 12226.5 & 2925 & 29.55 & 105 & 1.06 & 315 & 3.18 & 142 & 1.43 \\
\hline & $\mathbf{s} 27$ & 20 & 82.6 & 15453.5 & 3697 & 44.76 & 86 & 1.04 & 507 & 6.14 & 139 & 1.68 \\
\hline & $\mathbf{S 2 8}$ & 22 & 102.6 & 10600.5 & 2536 & 24.72 & 83 & 0.81 & 190 & 1.85 & 72 & 0.70 \\
\hline & $\mathbf{S 2 9}$ & 21 & 72.1 & 10805.3 & 2585 & 35.85 & 73 & 1.01 & 422 & 5.85 & 74 & 1.03 \\
\hline & 530 & 23 & 99.7 & 11135.5 & 2664 & 26.72 & 131 & 1.31 & 344 & 3.45 & 87 & 0.87 \\
\hline & $\$ 32$ & 23 & 83.6 & 13020.7 & 3115 & 37.26 & 101 & 1.21 & 407 & 4.87 & 105 & 1.26 \\
\hline & $\mathbf{s 3 3}$ & & & & & & & & & & & \\
\hline & 534 & 24 & 100.6 & 6855.2 & 1640 & 16.30 & 58 & 0.58 & 176 & 1.75 & 80 & 0.80 \\
\hline & $\$ 35$ & 22 & 72.6 & 8803.1 & 2106 & 29.01 & 108 & 1.49 & 266 & 3.66 & 72 & 0.99 \\
\hline & S36 & 21 & 97.5 & 20130.9 & 4816 & 49.39 & 155 & 1.59 & 600 & 6.15 & 197 & 2.02 \\
\hline
\end{tabular}


Diet Record Raw Data: 6 wk

\begin{tabular}{|c|c|c|c|c|c|c|c|c|c|c|c|c|}
\hline & Subject & Age & Wt (kg) & avg kJ & avg kcal & kcal/kg & PRO & PRO/kg & $\mathrm{CHO}$ & $\mathrm{CHO} / \mathrm{kg}$ & FAT & FAT/kg \\
\hline \multirow[t]{11}{*}{ Group 1} & s1 & 18 & 51.0 & 13070.9 & 3127 & 61.31 & 107 & 2.10 & 454 & 8.90 & 100 & 1.96 \\
\hline & S2 & 19 & 101.5 & 17217.4 & 4119 & 40.58 & 128 & 1.26 & 718 & 7.07 & 98 & 0.97 \\
\hline & S3 & 22 & 84.7 & 17188.2 & 4112 & 48.55 & 155 & 1.83 & 489 & 5.77 & 129 & 1.52 \\
\hline & S4 & 22 & 76.4 & 9066.4 & 2169 & 28.39 & 70 & 0.92 & 392 & 5.13 & 42 & 0.55 \\
\hline & S5 & 20 & 82.0 & 11469.9 & 2744 & 33.46 & 141 & 1.72 & 320 & 3.90 & 94 & 1.15 \\
\hline & S6 & 32 & 81.5 & 15064.7 & 3604 & 44.22 & 143 & 1.75 & 451 & 5.53 & 150 & 1.84 \\
\hline & 57 & 31 & 74.3 & 11357.1 & 2717 & 36.57 & 130 & 1.75 & 501 & 6.74 & 131 & 1.76 \\
\hline & s9 & 21 & 79.8 & 8598.3 & 2057 & 25.78 & 83 & 1.04 & 296 & 3.71 & 57 & 0.71 \\
\hline & s10 & 21 & 100.0 & 11549.3 & 2763 & 27.63 & 102 & 1.02 & 365 & 3.65 & 102 & 1.02 \\
\hline & $S 11$ & 22 & 77.0 & 25610.9 & 6127 & 79.57 & 249 & 3.23 & 560 & 7.27 & 216 & 2.81 \\
\hline & $\mathrm{S} 12$ & 22 & 69.0 & 18605.2 & 4451 & 64.51 & 167 & 2.42 & 519 & 7.52 & 149 & 2.16 \\
\hline \multirow[t]{12}{*}{ Group 2} & $\mathbf{S 1 3}$ & 32 & 71.8 & 10032.0 & 2400 & 33.43 & 86 & 1.20 & 296 & 4.12 & 100 & 1.39 \\
\hline & S14 & 20 & 73.1 & 12243.2 & 2929 & 40.07 & 131 & 1.79 & 388 & 5.31 & 87 & 1.19 \\
\hline & $\$ 15$ & 20 & 72.5 & 8364.2 & 2001 & 27.60 & 93 & 1.28 & 230 & 3.17 & 81 & 1.12 \\
\hline & s16 & 22 & 91.0 & 12163.8 & 2910 & 31.98 & 113 & 1.24 & 420 & 4.62 & 69 & 0.76 \\
\hline & s17 & 23 & 87.5 & 14349.9 & 3433 & 39.23 & 97 & 1.11 & 398 & 4.55 & 83 & 0.95 \\
\hline & $S 18$ & 22 & 97.3 & 15428.4 & 3691 & 37.93 & 172 & 1.77 & 435 & 4.47 & 130 & 1.34 \\
\hline & $S 19$ & 22 & 86.3 & 12802.1 & 3063 & 35.49 & 128 & 1.48 & 363 & 4.20 & 96 & 1.11 \\
\hline & $\mathrm{S} 20$ & 19 & 68.3 & 12280.8 & 2938 & 43.02 & 135 & 1.98 & 41 & 0.60 & 60 & 0.88 \\
\hline & $\mathrm{S} 21$ & 21 & 74.1 & 8723.7 & 2087 & 28.16 & 117 & 1.58 & 344 & 4.64 & 103 & 1.39 \\
\hline & $\$ 22$ & 23 & 92.5 & 8360.0 & 2000 & 21.62 & 84 & 0.91 & 272 & 2.94 & 68 & 0.74 \\
\hline & $\$ 23$ & 21 & 81.5 & 15269.5 & 3653 & 44.82 & 153 & 1.88 & 382 & 4.69 & 146 & 1.79 \\
\hline & $\$ 24$ & 32 & 92.0 & 17861.1 & 4273 & 46.45 & 178 & 1.93 & 557 & 6.05 & 156 & 1.70 \\
\hline \multirow[t]{8}{*}{ Group 3} & $\mathrm{~S} 25$ & 19 & 71.5 & 14450.3 & 3457 & 48.35 & 234 & 3.27 & 421 & 5.89 & 98 & 1.37 \\
\hline & $\mathbf{S} 26$ & 19 & 100.0 & 12824.2 & 3068 & 30.68 & 139 & 1.39 & 336 & 3.36 & 117 & 1.17 \\
\hline & $\mathbf{S 2 7}$ & 20 & 81.0 & 13610.1 & 3256 & 40.20 & 146 & 1.80 & 440 & 5.43 & 98 & 1.21 \\
\hline & $\mathbf{S 2 8}$ & 22 & 101.7 & 15311.3 & 3663 & 36.02 & 130 & 1.28 & 308 & 3.03 & 115 & 1.13 \\
\hline & $\mathbf{S 2 9}$ & 21 & 73.9 & 9317.2 & 2229 & 30.16 & 91 & 1.23 & 299 & 4.05 & 78 & 1.06 \\
\hline & S30 & 23 & 104.6 & 11867.0 & 2839 & 27.14 & 165 & 1.58 & 312 & 2.98 & 108 & 1.03 \\
\hline & $\mathbf{S 3 2}$ & 23 & 87.9 & 15386.6 & 3681 & 41.88 & 158 & 1.80 & 410 & 4.66 & 147 & 1.67 \\
\hline & $\mathbf{S 3 3}$ & 25 & 78.9 & 10353.9 & 2477 & 31.39 & 107 & 1.36 & 298 & 3.78 & 98 & 1.24 \\
\hline \multirow[t]{3}{*}{ Omitted } & $\mathbf{S 3 4}$ & 24 & 102.4 & 4226.0 & 1011 & 9.87 & 46 & 0.45 & 130 & 1.27 & 38 & 0.37 \\
\hline & $\mathbf{S 3 5}$ & 22 & 72.6 & 13405.3 & 3207 & 44.17 & 186 & 2.56 & 269 & 3.71 & 150 & 2.07 \\
\hline & S36 & 21 & 104.1 & 16929.0 & 4050 & 38.90 & 114 & 1.10 & 508 & 4.88 & 139 & 1.34 \\
\hline
\end{tabular}


Diet Record Raw Data: 12 wk

\begin{tabular}{|c|c|c|c|c|c|c|c|c|c|c|c|c|}
\hline & Subject & Age & Wt (kg) & avg kJ & avg kcal & kcal/kg & PRO & PRO/kg & CHO & $\mathrm{CHO} / \mathrm{kg}$ & FAT & FAT/kg \\
\hline \multirow[t]{11}{*}{ Group 1} & s1 & 18 & 50.8 & 12966.4 & 3102 & 61.06 & 134 & 2.64 & 390 & 7.68 & 116 & 2.28 \\
\hline & S2 & 19 & 101.0 & 23508.3 & 5624 & 55.68 & 191 & 1.89 & 904 & 8.95 & 172 & 1.70 \\
\hline & S3 & 22 & 85.0 & 11908.8 & 2849 & 33.52 & 113 & 1.33 & 289 & 3.40 & 121 & 1.42 \\
\hline & S4 & 22 & 80.0 & 13572.5 & 3247 & 40.59 & 101 & 1.26 & 518 & 6.48 & 93 & 1.16 \\
\hline & S5 & 20 & 80.0 & 11068.6 & 2648 & 33.10 & 95 & 1.19 & 383 & 4.79 & 84 & 1.05 \\
\hline & S6 & 32 & 82.0 & 9116.6 & 2181 & 26.60 & 77 & 0.94 & 294 & 3.59 & 83 & 1.01 \\
\hline & S7 & 31 & 77.3 & 10073.8 & 2410 & 31.18 & 87 & 1.13 & 342 & 4.42 & 78 & 1.01 \\
\hline & s9 & 21 & 83.4 & 12673.8 & 3032 & 36.35 & 129 & 1.55 & 453 & 5.43 & 81 & 0.97 \\
\hline & 510 & 21 & 99.9 & 13735.5 & 3286 & 32.89 & 144 & 1.44 & 360 & 3.60 & 144 & 1.44 \\
\hline & $\mathbf{s 1 1}$ & 22 & 78.0 & 26547.2 & 6351 & 81.42 & 288 & 3.69 & 531 & 6.81 & 279 & 3.58 \\
\hline & $\mathrm{S} 12$ & 22 & 68.2 & 15695.9 & 3755 & 55.06 & 175 & 2.57 & 468 & 6.86 & 137 & 2.01 \\
\hline \multirow[t]{12}{*}{ Group 2} & $s 13$ & 32 & 72.3 & 9471.9 & 2266 & 31.34 & 95 & 1.31 & 306 & 4.23 & 75 & 1.04 \\
\hline & $\mathrm{S} 14$ & 20 & 71.8 & 14345.8 & 3432 & 47.80 & 132 & 1.84 & 448 & 6.24 & 128 & 1.78 \\
\hline & $\mathbf{S 1 5}$ & 20 & 74.2 & 14496.2 & 3468 & 46.74 & 163 & 2.20 & 412 & 5.55 & 131 & 1.77 \\
\hline & S16 & 22 & 94.0 & 12715.6 & 3042 & 32.36 & 130 & 1.38 & 411 & 4.37 & 100 & 1.06 \\
\hline & s17 & 23 & 87.5 & 9806.3 & 2346 & 26.81 & 102 & 1.17 & 265 & 3.03 & 49 & 0.56 \\
\hline & $\$ 18$ & 22 & 96.1 & 11921.4 & 2852 & 29.68 & 113 & 1.18 & 342 & 3.56 & 110 & 1.14 \\
\hline & $\mathbf{s} 19$ & 22 & 86.0 & 10993.4 & 2630 & 30.58 & 116 & 1.35 & 305 & 3.55 & 78 & 0.91 \\
\hline & $\mathbf{S 2 0}$ & 19 & 69.2 & 13075.0 & 3128 & 45.20 & 146 & 2.11 & 448 & 6.47 & 87 & 1.26 \\
\hline & s21 & 21 & 75.8 & 12159.6 & 2909 & 38.38 & 127 & 1.68 & 359 & 4.74 & 109 & 1.44 \\
\hline & $\mathrm{S} 22$ & 23 & 94.0 & 11942.3 & 2857 & 30.39 & 120 & 1.28 & 405 & 4.31 & 92 & 0.98 \\
\hline & $\mathbf{S} 23$ & 21 & 83.5 & 16080.5 & 3847 & 46.07 & 201 & 2.41 & 395 & 4.73 & 139 & 1.66 \\
\hline & S24 & 32 & 89.5 & 19115.1 & 4573 & 51.09 & 169 & 1.89 & 650 & 7.26 & 144 & 1.61 \\
\hline \multirow[t]{11}{*}{ Group 3} & S25 & 19 & 71.8 & 14981.1 & 3584 & 49.92 & 216 & 3.01 & 394 & 5.49 & 122 & 1.70 \\
\hline & S26 & 19 & 103.3 & 13062.5 & 3125 & 30.25 & 154 & 1.49 & 278 & 2.69 & 130 & 1.26 \\
\hline & S27 & 20 & 82.0 & 9405.0 & 2250 & 27.44 & 79 & 0.96 & 305 & 3.72 & 69 & 0.84 \\
\hline & $\mathbf{S 2 8}$ & 22 & 102.1 & 11110.4 & 2658 & 26.03 & 141 & 1.38 & 281 & 2.75 & 89 & 0.87 \\
\hline & $\mathbf{S 2 9}$ & 21 & 73.3 & 9660.0 & 2311 & 31.53 & 69 & 0.94 & 366 & 4.99 & 73 & 1.00 \\
\hline & S30 & 23 & 104.4 & 9325.6 & 2231 & 21.37 & 114 & 1.09 & 253 & 2.42 & 87 & 0.83 \\
\hline & S32 & 23 & 91.4 & 13242.2 & 3168 & 34.66 & 167 & 1.83 & 389 & 4.26 & 106 & 1.16 \\
\hline & S33 & 25 & 80.8 & 10633.9 & 2544 & 31.50 & 106 & 1.31 & 336 & 4.16 & 84 & 1.04 \\
\hline & S34 & 24 & 103.6 & 8431.1 & 2017 & 19.47 & 106 & 1.02 & 269 & 2.60 & 61 & 0.59 \\
\hline & S35 & 22 & 73.0 & 9329.8 & 2232 & 30.58 & 100 & 1.37 & 290 & 3.97 & 82 & 1.12 \\
\hline & S36 & 21 & 108.5 & 26530.5 & 6347 & 58.50 & 160 & 1.47 & 803 & 7.40 & 196 & 1.81 \\
\hline
\end{tabular}




\section{Diet Record Raw Data Summary}

Pre Training

\begin{tabular}{|c|c|c|c|c|c|c|c|c|c|c|c|}
\hline & Age & Wt (kg) & avg kJ & avg kcal & $\mathrm{kcal} / \mathrm{kg}$ & PRO & PRO/kg & $\mathrm{CHO}$ & CHO/kg & FAT & FAT/kg \\
\hline MEAN & 22 & 82.25 & 12227.77 & 2925.30 & 36.17 & 106.21 & 1.32 & 386 & 4.79 & 101.36 & 1.26 \\
\hline SD & 4 & 12.73 & 3328.23 & 796.23 & 10.26 & 27.65 & 0.37 & 132 & 1.72 & 31.53 & 0.39 \\
\hline SE & 1 & 2.18 & 570.79 & 136.55 & 1.76 & 4.74 & 0.06 & 23 & 0.29 & 5.41 & 0.07 \\
\hline
\end{tabular}

\section{$6 \mathrm{Wk}$}

\begin{tabular}{|c|c|c|c|c|c|c|c|c|c|c|c|}
\hline & Age & Wt (kg) & avg kJ & avg kcal & kcal $/ \mathbf{k g}$ & PRO & PRO/kg & $\mathrm{CHO}$ & CHO/kg & FAT & FAT/kg \\
\hline MEAN & 22.53 & 83.64 & 13069.35 & 3126.64 & 38.21 & 131.69 & 1.62 & 380.04 & 4.64 & 106.85 & 1.31 \\
\hline$S D$ & 3.74 & 12.80 & 3924.67 & 938.92 & 12.82 & 42.90 & 0.61 & 126.79 & 1.70 & 37.15 & 0.50 \\
\hline SE & 0.64 & 2.20 & 673.08 & 161.02 & 2.20 & 7.36 & 0.10 & 21.75 & 0.29 & 6.37 & 0.09 \\
\hline
\end{tabular}

\section{Wk}

\begin{tabular}{|c|c|c|c|c|c|c|c|c|c|c|c|}
\hline & Age & Wt (kg) & avg kJ & avg kcal & kcal/kg & PRO & PRO/kg & $\mathrm{CHO}$ & CHO/kg & FAT & FAT/kg \\
\hline MEAN & 22.53 & 84.52 & 13314.78 & 3185.35 & 38.39 & 134.12 & 1.63 & 401.24 & 4.84 & 109.68 & 1.33 \\
\hline SD & 3.74 & 13.05 & 4526.79 & 1082.96 & 13.22 & 45.01 & 0.63 & 144.25 & 1.65 & 43.87 & 0.57 \\
\hline SE & 0.64 & 2.24 & 776.34 & 185.73 & 2.27 & 7.72 & 0.11 & 24.74 & 0.28 & 7.52 & 0.10 \\
\hline
\end{tabular}


Average KJ ANOVA for all time points

\begin{tabular}{|c|c|c|c|c|c|}
\hline & SS & Degr. of & MS & $F$ & p-level \\
\hline Group & $3.966195 \mathrm{E}+07$ & 2 & $1.983098 \mathrm{E}+07$ & 0.5654 & 0.574069 \\
\hline Error & $1.052225 \mathrm{E}+09$ & 30 & $3.507417 \mathrm{E}+07$ & & \\
\hline TIME & $2.458279 \mathrm{E}+07$ & 2 & $1.229139 \mathrm{E}+07$ & 1.7692 & 0.179254 \\
\hline TIME*Group & $1.525160 \mathrm{E}+07$ & 4 & $3.812901 \mathrm{E}+06$ & 0.5488 & 0.700576 \\
\hline Error & $4.168571 \mathrm{E}+08$ & 60 & $6.947619 \mathrm{E}+06$ & \\
\hline
\end{tabular}

Average PRO ANOVA for all time points

\begin{tabular}{|c|c|c|c|c|c|}
\hline & SS & Degr. of & MS & F & P \\
\hline Group & 4 & 2 & 2 & 0.0006 & 0.999366 \\
\hline Error & 90334 & 30 & 3011 & & \\
\hline TIME & 17321 & 2 & 8661 & 9.1424 & 0.000342 \\
\hline TIME*Group & 3442 & 4 & 860 & 0.9083 & 0.464981 \\
\hline Error & 56838 & 60 & 947 & & \\
\hline
\end{tabular}

Average PRO/kg ANOVA for all time points

\begin{tabular}{|c|c|c|c|c|c|}
\hline & SS & Degr. of & MS & F & p \\
\hline Group & 0.5117 & 2 & 0.2559 & 0.3898 & 0.680563 \\
\hline Error & 19.6913 & 30 & 0.6564 & & \\
\hline TIME & 2.2669 & 2 & 1.1334 & 7.8953 & 0.000904 \\
\hline TIME*Group & 0.7159 & 4 & 0.1790 & 1.2467 & 0.301003 \\
\hline Error & 8.6135 & 60 & 0.1436 & & \\
\hline
\end{tabular}

Average CHO ANOVA for all time points

\begin{tabular}{|c|c|c|c|c|c|}
\hline & SS & Degr. Of & MS & F & p \\
\hline Group & 132337 & 2 & 66168 & 1.8155 & 0.180187 \\
\hline Error & 1093390 & 30 & 36446 & & \\
\hline TIME & 7448 & 2 & 3724 & 0.4347 & 0.649465 \\
\hline TIME*Group & 22824 & 4 & 5706 & 0.6661 & 0.618029 \\
\hline Error & 513999 & 60 & 8567 & & \\
\hline
\end{tabular}


Average CHO/kg ANOVA for all time points

\begin{tabular}{|c|c|c|c|c|c|}
\hline & SS & Degr. Of & MS & F & P \\
\hline Group & 38.790 & 2 & 19.395 & 3.9110 & 0.030950 \\
\hline Error & 148.775 & 30 & 4.959 & & \\
\hline TIME & 0.542 & 2 & 0.271 & 0.1936 & 0.824495 \\
\hline TIME*Group & 6.408 & 4 & 1.602 & 1.1448 & 0.344288 \\
\hline Error & 83.967 & 60 & 1.399 & & \\
\hline
\end{tabular}


APPENDIX 2

SUBJECT CHARACTERISTICS 
Subject Characteristics Pre

\begin{tabular}{|c|c|c|c|c|c|}
\hline & Subject & Age & $\begin{array}{l}\text { Weight } \\
(\mathrm{kg})\end{array}$ & $\begin{array}{l}\text { Height } \\
\text { (m) }\end{array}$ & $\begin{array}{l}\mathrm{BMI} \\
(\mathrm{kg} / \mathrm{m} 2)\end{array}$ \\
\hline Group 1 & S1 & 18 & 51.8 & 180 & 15.99 \\
\hline & S2 & 19 & 100.0 & 1.87 & 28.60 \\
\hline & 53 & 22 & 84.6 & 1.86 & 24.59 \\
\hline & S4 & 22 & 77.7 & 1.73 & 25.96 \\
\hline & S5 & 20 & 82.1 & 1.81 & 25.14 \\
\hline & S6 & 32 & 81.0 & 1.83 & 24.21 \\
\hline & S7 & 31 & 75.6 & 1.68 & 26.91 \\
\hline & s9 & 21 & 75.5 & 1.85 & 22.06 \\
\hline & $S 10$ & 21 & 99.5 & 1.74 & 33.05 \\
\hline & $\mathrm{s} 11$ & 22 & 75.1 & 1.93 & 20.16 \\
\hline & $\mathrm{S} 12$ & 22 & 67.2 & 1.73 & 22.45 \\
\hline Group 2 & $\mathrm{~S} 13$ & 32 & 68.0 & 1.80 & 20.99 \\
\hline & $\mathrm{S} 14$ & 20 & 72.8 & 1.83 & 21.86 \\
\hline & $\mathrm{S} 15$ & 20 & 71.5 & 1.84 & 21.12 \\
\hline & $\mathrm{S} 16$ & 22 & 89.5 & 1.87 & 25.59 \\
\hline & $\mathrm{S} 17$ & 23 & 83.5 & 1.86 & 24.14 \\
\hline & $\mathrm{S} 18$ & 22 & 96.6 & 1.72 & 32.65 \\
\hline & $\mathrm{S} 19$ & 22 & 82.5 & 1.81 & 25.18 \\
\hline & $\mathrm{S} 20$ & 19 & 64.0 & 1.73 & 21.38 \\
\hline & $S 21$ & 21 & 70.0 & 1.74 & 23.25 \\
\hline & $\mathrm{S} 22$ & 23 & 92.8 & 1.78 & 29.29 \\
\hline & $\mathbf{S 2 3}$ & 21 & 82.0 & 1.82 & 24.76 \\
\hline & S24 & 32 & 90.5 & 1.85 & 26.44 \\
\hline Group 3 & $\mathrm{~S} 25$ & 19 & 70.0 & 1.87 & 20.02 \\
\hline & S26 & 19 & 99.0 & 1.82 & 29.89 \\
\hline & S27 & 20 & 82.6 & 1.73 & 27.60 \\
\hline & $\mathrm{S} 28$ & 22 & 102.6 & 1.83 & 30.64 \\
\hline & $\mathbf{S} 29$ & 21 & 72.1 & 1.78 & 22.76 \\
\hline & 530 & 23 & 99.7 & 1.84 & 29.61 \\
\hline & $\mathrm{S} 32$ & 23 & 83.6 & 1.80 & 25.80 \\
\hline & $\mathrm{S} 33$ & 25 & 78.0 & 1.74 & 25.76 \\
\hline & S34 & 24 & 100.6 & 1.77 & 32.11 \\
\hline & $\mathrm{S} 35$ & 22 & 72.6 & 1.55 & 30.22 \\
\hline & S36 & 21 & 97.5 & 1.78 & 30.95 \\
\hline$N=$ & 34 & & & & \\
\hline Mean & & 22.5 & 82.1 & 1.79 & 25.62 \\
\hline SD & & 4 & 12.6 & 0.07 & 4.10 \\
\hline$S E$ & & 1 & 2.2 & 0.01 & 0.70 \\
\hline
\end{tabular}


Subject Characteristics Post

\begin{tabular}{|c|c|c|c|c|c|}
\hline & Subject & Age & $\begin{array}{l}\text { Weight } \\
\text { (kg) }\end{array}$ & $\begin{array}{l}\text { Height } \\
\text { (m) }\end{array}$ & $\begin{array}{l}\mathrm{BMI} \\
(\mathrm{kg} / \mathrm{m} 2)\end{array}$ \\
\hline Group 1 & S1 & 18 & 50.7 & 1.80 & 15.74 \\
\hline & 52 & 19 & 100.5 & 1.87 & 28.74 \\
\hline & 53 & 22 & 86.0 & 1.86 & 24.70 \\
\hline & 54 & 22 & 79.8 & 1.73 & 26.40 \\
\hline & S5 & 20 & 80.5 & 1.81 & 24.81 \\
\hline & $\mathrm{S6}$ & 32 & 81.5 & 1.83 & 24.33 \\
\hline & S7 & 31 & 76.2 & 1.68 & 27.77 \\
\hline & 59 & 21 & 83.3 & 1.85 & 23.78 \\
\hline & S10 & 21 & 99.8 & 1.74 & 33.32 \\
\hline & $\mathrm{S} 11$ & 22 & 79.1 & 1.93 & 20.81 \\
\hline & $\mathrm{S} 12$ & 22 & 68.3 & 1.73 & 22.75 \\
\hline Group 2 & $\mathrm{~S} 13$ & 32 & 71.9 & 1.80 & 22.31 \\
\hline & $\mathrm{S} 14$ & 20 & 71.8 & 1.83 & 21.80 \\
\hline & $\mathrm{S} 15$ & 20 & 74.4 & 1.84 & 21.30 \\
\hline & $\mathrm{S} 16$ & 22 & 92.5 & 1.87 & 26.45 \\
\hline & $\mathrm{S} 17$ & 23 & 88.5 & 1.86 & 25.87 \\
\hline & $\mathrm{S} 18$ & 22 & 96.3 & 1.72 & 32.96 \\
\hline & $\mathbf{S 1 9}$ & 22 & 85.8 & 1.81 & 26.34 \\
\hline & $\mathrm{S} 20$ & 19 & 68.9 & 1.73 & 22.89 \\
\hline & $\mathbf{S} 21$ & 21 & 76.7 & 1.74 & 24.92 \\
\hline & $\mathrm{S} 22$ & 23 & 94.9 & 1.78 & 29.29 \\
\hline & $\mathrm{S} 23$ & 21 & 83.9 & 1.82 & 25.27 \\
\hline & S24 & 32 & 89.8 & 1.85 & 26.56 \\
\hline Group 3 & $S 25$ & 19 & 71.4 & 1.87 & 20.59 \\
\hline & S26 & 19 & 105.2 & 1.82 & 31.46 \\
\hline & S27 & 20 & 81.3 & 1.73 & 27.40 \\
\hline & $\mathrm{S} 28$ & 22 & 102.3 & 1.83 & 30.94 \\
\hline & S29 & 21 & 73.5 & 1.78 & 23.04 \\
\hline & $\mathrm{S} 30$ & 23 & 104.1 & 1.84 & 30.83 \\
\hline & $\mathrm{S} 32$ & 23 & 91.6 & 1.80 & 27.65 \\
\hline & S33 & 25 & 80.9 & 1.74 & 26.42 \\
\hline & S34 & 24 & 104.1 & 1.77 & 32.56 \\
\hline & $\mathrm{S} 35$ & 22 & 72.7 & 1.55 & 29.97 \\
\hline & S36 & 21 & 109.8 & 1.78 & 34.25 \\
\hline$N=$ & 34 & & & & \\
\hline Mean & & 22.5 & 84.6 & 1.79 & 26.30 \\
\hline$S D$ & & 4 & 13.2 & 0.07 & 4.22 \\
\hline $\mathrm{SE}$ & & 1 & 2.3 & 0.01 & 0.72 \\
\hline
\end{tabular}




\section{APPENDIX 3}

BODY COMPOSITION RAW DATA DETERMINED BY DXA, AND ANOVA TABLES 
DXA scan results Pre training

\begin{tabular}{|c|c|c|c|c|c|c|c|}
\hline & Subject & Fat (grams) & $\begin{array}{l}\text { Lean + } \\
\text { BMC } \\
\text { (grams) }\end{array}$ & $\begin{array}{l}\text { BMC } \\
\text { (grams) }\end{array}$ & $\begin{array}{l}\text { Lean } \\
\text { (grams) }\end{array}$ & $\%$ Fat & $\begin{array}{l}\text { Total } \\
\text { (grams) }\end{array}$ \\
\hline \multirow[t]{11}{*}{$\begin{array}{l}\text { Group } \\
1\end{array}$} & s1 & 5271.90 & 44025.00 & 1877.04 & 42147.96 & 10.69 & 49296.90 \\
\hline & $\mathrm{S} 2$ & 27615.70 & 69851.80 & 3323.14 & 66528.66 & 28.33 & 97467.50 \\
\hline & 53 & 9810.40 & 71754.50 & 2974.04 & 68780.46 & 12.03 & 81564.90 \\
\hline & S4 & 15164.40 & 61447.10 & 2518.37 & 58928.73 & 19.79 & 76611.50 \\
\hline & S5 & 18873.50 & 62060.30 & 2831.28 & 59229.02 & 23.32 & 80933.80 \\
\hline & S6 & 10173.70 & 68840.40 & 3087.86 & 65752.54 & 12.88 & 79014.10 \\
\hline & S7 & 14814.00 & 61245.90 & 2577.13 & 58668.77 & 19.48 & 76059.90 \\
\hline & s9 & 7958.50 & 65435.00 & 2637.30 & 62797.70 & 10.84 & 73393.50 \\
\hline & $\mathrm{S} 10$ & 23644.50 & 75431.00 & 3024.14 & 72406.86 & 23.87 & 99075.50 \\
\hline & S11 & 7242.80 & 66108.40 & 2736.76 & 63371.64 & 9.87 & 73351.20 \\
\hline & $\mathrm{S} 12$ & 8354.60 & 57038.20 & 2643.68 & 54394.52 & 12.78 & 65392.80 \\
\hline \multirow[t]{12}{*}{$\begin{array}{l}\text { Group } \\
2\end{array}$} & $\mathrm{~S} 13$ & 8517.80 & 57902.70 & 2610.47 & 55292.23 & 12.82 & 66420.50 \\
\hline & S14 & 9429.70 & 60082.10 & 2355.25 & 57726.85 & 13.57 & 69511.80 \\
\hline & S15 & 6808.20 & 63845.40 & 2611.05 & 61234.35 & 9.64 & 70653.60 \\
\hline & $S 16$ & 11526.20 & 75195.90 & 3231.89 & 71964.01 & 13.29 & 86722.10 \\
\hline & S17 & 14216.00 & 69115.30 & 2928.53 & 66186.77 & 17.06 & 83331.30 \\
\hline & $\mathrm{S} 18$ & 17867.20 & 80149.10 & 3376.72 & 76772.38 & 18.23 & 98016.30 \\
\hline & S19 & 15871.20 & 64873.30 & 2956.21 & 61917.09 & 19.66 & 80744.50 \\
\hline & $\mathrm{S} 20$ & 8936.30 & 54475.70 & 2643.32 & 51832.38 & 14.09 & 63412.00 \\
\hline & S21 & 8388.80 & 59716.20 & 2716.94 & 56999.26 & 12.32 & 68105.00 \\
\hline & $\mathrm{S} 22$ & 20700.50 & 69279.90 & 2750.80 & 66529.10 & 23.01 & 89980.40 \\
\hline & $\mathrm{S} 23$ & 15686.50 & 64994.80 & 3208.03 & 61786.77 & 19.44 & 80681.30 \\
\hline & S24 & 14853.40 & 74242.30 & 3259.27 & 70983.03 & 16.67 & 89095.70 \\
\hline \multirow[t]{11}{*}{$\begin{array}{l}\text { Group } \\
3\end{array}$} & S25 & 8849.30 & 58551.70 & 2644.28 & 55907.42 & 13.13 & 67401.00 \\
\hline & $S 26$ & 19798.40 & 78765.30 & 3304.20 & 75461.10 & 20.09 & 98563.70 \\
\hline & $S 27$ & 13485.30 & 69264.30 & 3072.67 & 66191.63 & 16.30 & 82749.60 \\
\hline & $\mathrm{S} 28$ & 22271.30 & 82800.60 & 3474.85 & 79325.75 & 21.20 & 105071.90 \\
\hline & $S 29$ & 13959.20 & 57281.90 & 2481.35 & 54800.55 & 19.59 & 71241.10 \\
\hline & 530 & 24310.40 & 75579.20 & 3551.34 & 72027.86 & 24.34 & 99889.60 \\
\hline & S32 & 12881.00 & 70293.60 & 3099.37 & 67194.23 & 15.49 & 83174.60 \\
\hline & S33 & 11082.20 & 66351.80 & 2965.36 & 63386.44 & 14.31 & 77434.00 \\
\hline & $\mathrm{S} 34$ & 28629.30 & 72115.80 & 3269.49 & 68846.31 & 28.42 & 100745.10 \\
\hline & S35 & 18902.10 & 52721.10 & 2251.42 & 50469.68 & 26.39 & 71623.20 \\
\hline & $\mathrm{S} 36$ & 18431.90 & 78950.30 & 3565.58 & 75384.72 & 18.93 & 97382.20 \\
\hline & & & & & & & \\
\hline $\mathrm{N}=$ & 34 & & & & & & \\
\hline Mean & & 14539.01 & 66464.29 & 2898.80 & 63565.49 & 17.41 & 81003.30 \\
\hline SD & & 6159.92 & 8690.14 & 392.41 & 8335.89 & 5.29 & 13146.91 \\
\hline $\mathrm{SE}$ & & 1056.42 & 1490.35 & 67.30 & 1429.59 & 0.91 & 2254.68 \\
\hline
\end{tabular}


DXA scan results Post training

\begin{tabular}{|c|c|c|c|c|c|c|c|}
\hline & Subject & $\begin{array}{l}\text { Fat } \\
\text { (grams) }\end{array}$ & $\begin{array}{l}\text { Lean + BMC } \\
\text { (grams) }\end{array}$ & $\begin{array}{l}\text { BMC } \\
\text { (grams) }\end{array}$ & $\begin{array}{l}\text { Lean } \\
\text { (grams) }\end{array}$ & $\%$ Fat & $\begin{array}{l}\begin{array}{l}\text { Total } \\
\text { (grams) }\end{array} \\
\end{array}$ \\
\hline \multirow[t]{11}{*}{ Group 1} & s1 & 4567.5 & 44740.6 & 1837.3 & 42903.4 & 9.3 & 49308.1 \\
\hline & S2 & 24168.4 & 74847.3 & 3338.9 & 71508.5 & 24.4 & 99015.8 \\
\hline & S3 & 11967.8 & 73870.0 & 3103.4 & 70766.7 & 13.9 & 85837.9 \\
\hline & 54 & 16327.5 & 62738.8 & 2605.9 & 60132.9 & 20.7 & 79066.3 \\
\hline & S5 & 16497.6 & 62625.7 & 2804.6 & 59821.0 & 20.9 & 79123.3 \\
\hline & S6 & 10866.5 & 70442.9 & 3145.0 & 67298.0 & 13.4 & 81309.4 \\
\hline & S7 & 13989.5 & 62003.1 & 2484.7 & 59518.3 & 18.4 & 75992.6 \\
\hline & s9 & 10223.6 & 71582.5 & 2752.6 & 68829.9 & 12.5 & 81806.2 \\
\hline & S10 & 22633.0 & 76138.9 & 3048.3 & 73090.6 & 22.9 & 98771.9 \\
\hline & $\mathrm{s} 11$ & 7007.4 & 70313.2 & 2692.0 & 67621.1 & 9.1 & 77320.5 \\
\hline & $\mathrm{S} 12$ & 7996.5 & 58542.6 & 2653.1 & 55889.5 & 12.0 & 66539.1 \\
\hline Group 2 & $\mathrm{~S} 13$ & 8275.6 & 61039.8 & 2635.0 & 58404.9 & 11.9 & 69315.5 \\
\hline \multirow[t]{4}{*}{${ }^{*}$} & S14 & 8648.8 & 59287.4 & 2206.8 & 57080.6 & 12.7 & 67936.2 \\
\hline & $\mathrm{S} 15$ & 7085.1 & 66448.7 & 2686.7 & 63762 & 9.6 & 73533.8 \\
\hline & S16 & 11748.4 & 78762 & 3308.4 & 75453.6 & 13 & 90510.4 \\
\hline & $\mathrm{S} 17$ & 14105.8 & 72369.3 & 3001.3 & 69368 & 16.3 & 86475.1 \\
\hline \multirow[t]{7}{*}{ * } & S18 & 14597.6 & 79171.4 & 3310.1 & 75861.3 & 15.6 & 93769.0 \\
\hline & $S 19$ & 16363.1 & 68382.1 & 2977.6 & 65404.5 & 19.3 & 84745.2 \\
\hline & $S 20$ & 8213.3 & 59492.8 & 2760.9 & 56731.9 & 12.1 & 67706.1 \\
\hline & $\mathrm{S} 21$ & 10397.7 & 66871.8 & 2839.8 & 64032.0 & 13.5 & 77269.4 \\
\hline & $\mathrm{S} 22$ & 20557.7 & 69891.8 & 2829.6 & 67062.2 & 22.7 & 90449.4 \\
\hline & $S 23$ & 13947.3 & 69259.7 & 3197.9 & 66061.8 & 16.8 & 83207.0 \\
\hline & S24 & 13429.8 & 74694.0 & 3327.6 & 71366.4 & 15.2 & 88123.8 \\
\hline \multirow[t]{11}{*}{ Group 3} & $\mathbf{S 2 5}$ & 8629.5 & 61218.3 & 2707.9 & 58510.4 & 12.4 & 69847.8 \\
\hline & $S 26$ & 22361.6 & 81654.6 & 3212.1 & 78442.5 & 21.5 & 104016.1 \\
\hline & $\mathrm{S} 27$ & 10201.3 & 70187.6 & 2957.9 & 67229.6 & 12.7 & 80388.8 \\
\hline & $S 28$ & 19109.1 & 82907.6 & 3449.2 & 79458.4 & 18.7 & 102016.7 \\
\hline & $S 29$ & 12233.4 & 58061.6 & 2459.5 & 55602.1 & 17.4 & 70294.9 \\
\hline & S30 & 24512.0 & 78504.0 & 3597.4 & 74906.6 & 23.8 & 103016.1 \\
\hline & S32 & 15951.9 & 75045.5 & 3219.7 & 71825.8 & 17.5 & 90997.4 \\
\hline & 533 & 11301.6 & 68826.9 & 2969.8 & 65857.1 & 14.1 & 80128.4 \\
\hline & S34 & 28803.2 & 75471.6 & 3266.6 & 72205.0 & 27.6 & 104274.8 \\
\hline & S35 & 18187.2 & 53728.3 & 2283.8 & 51444.5 & 25.3 & 71915.4 \\
\hline & S36 & 23502.7 & 86747.7 & 3801.6 & 82946.1 & 21.3 & 110250.4 \\
\hline $\mathrm{N}=$ & 34 & & & & & & \\
\hline Mean & & 14364.97 & 68996.18 & 2925.68 & 66070.51 & 16.72 & 83361.14 \\
\hline SD & & 6000.46 & 9047.14 & 412.59 & 8666.44 & 4.98 & 13491.19 \\
\hline SE & & 1029.07 & 1551.57 & 70.76 & 1486.28 & 0.85 & 2313.72 \\
\hline
\end{tabular}

*DXA chopper cut off error during scans, inaccurate results and were not included in analysis 
FBFM ANOVA Pre vs Post.

\begin{tabular}{|c|c|c|c|c|c|}
\hline & SS & Degr. of & MS & F & P \\
\hline Group & 10369 & 2 & 5185 & 1.239 & 0.303528 \\
\hline Error & 129683 & 31 & 4183 & & \\
\hline TIME & 1707 & 1 & 1707 & 13.490 & 0.000899 \\
\hline TIME*Group & 296 & 2 & 148 & 1.170 & 0.323669 \\
\hline Error & 3923 & 31 & 127 & & \\
\hline
\end{tabular}

Body Fat \% ANOVA Pre vs Post

\begin{tabular}{|c|c|c|c|c|c|}
\hline & SS & Degr. of & MS & F & p \\
\hline Group & 216.98 & 2 & 108.49 & 2.2603 & 0.121249 \\
\hline Error & 1487.95 & 31 & 48.00 & & \\
\hline TIME & 7.83 & 1 & 7.83 & 6.1397 & 0.018871 \\
\hline TIME*Group & 0.53 & 2 & 0.26 & 0.2073 & 0.813869 \\
\hline Error & 39.56 & 31 & 1.28 & & \\
\hline
\end{tabular}

Total mass ANOVA Pre vs. Post

\begin{tabular}{|c|c|c|c|c|c|}
\hline & SS & Degr. of & MS & F & p \\
\hline Group & 1016.0 & 2 & 508.0 & 1.604 & 0.217258 \\
\hline Error & 9815.8 & 31 & 316.6 & & \\
\hline TIME & 105.6 & 1 & 105.6 & 22.156 & 0.000050 \\
\hline TIME*Group & 12.0 & 2 & 6.0 & 1.256 & 0.298853 \\
\hline Error & 147.7 & 31 & 4.8 & & \\
\hline
\end{tabular}

Fat mass ANOVA Pre vs Post

\begin{tabular}{|c|c|c|c|c|c|}
\hline & SS & Degr. of & MS & F & p \\
\hline Group & $3.335941 \mathrm{E}+08$ & 2 & $1.667971 \mathrm{E}+08$ & 2.5251 & 0.096394 \\
\hline Error & $2.047749 \mathrm{E}+09$ & 31 & $6.605642 \mathrm{E}+07$ & & \\
\hline TIME & $4.653739 \mathrm{E}+05$ & 1 & $4.653739 \mathrm{E}+05$ & 0.2498 & 0.620745 \\
\hline TIME*Group & $1.259139 \mathrm{E}+06$ & 2 & $6.295695 \mathrm{E}+05$ & 0.3379 & 0.715835 \\
\hline Error & $5.775242 \mathrm{E}+07$ & 31 & $1.862981 \mathrm{E}+06$ & & \\
\hline
\end{tabular}


Lean mass gains one way ANOVA

\begin{tabular}{|l|c|c|c|c|c|}
\hline & SS & Degr. of & MS & F & P \\
\hline Group & 3.7252 & 2 & 1.8626 & 0.45793 & 0.637085 \\
\hline Error & 117.9536 & 29 & 4.0674 & & \\
\hline
\end{tabular}


APPENDIX 4

FIBRE AREA RAW DATA, AND ANOVA TABLES 
Fiber Area Pre

\begin{tabular}{|c|c|c|c|c|c|c|}
\hline Subject & & 1 & IIA & IIAX & IIIX & II (Pooled) \\
\hline 1 & & 4842 & 5156 & 4655 & 3756 & 4356 \\
\hline 2 & & 5020 & 7242 & 8089 & 7182 & 7148 \\
\hline 3 & & 5651 & 7253 & & 6841 & 6991 \\
\hline 4 & & 5447 & 7660 & & 6458 & 6992 \\
\hline 5 & & 4421 & 5614 & 6077 & 5461 & 5555 \\
\hline 6 & & 5554 & 6119 & & 5388 & 6031 \\
\hline 7 & & 5152 & 6034 & 5657 & 5410 & 5810 \\
\hline 9 & & 5442 & 6799 & & 5938 & 6413 \\
\hline 10 & & 7289 & 7909 & 9037 & 8055 & 7944 \\
\hline 11 & & & 6016 & & 5395 & 5679 \\
\hline 12 & & & 3214 & & 5348 & 4288 \\
\hline 13 & & 3937 & 5330 & 5399 & 5058 & 5204 \\
\hline 14 & & 5080 & 5608 & 5805 & 4408 & 4875 \\
\hline 15 & & 3939 & 5912 & & 5027 & 5558 \\
\hline 16 & & 3500 & 3690 & 3483 & 3054 & 3377 \\
\hline 17 & & 4467 & 4898 & 4395 & 4259 & 4683 \\
\hline 18 & & 3467 & 4560 & & 4435 & 4510 \\
\hline 19 & & 3959 & 5307 & & 4173 & 5199 \\
\hline 20 & & & & & & \\
\hline 21 & & 4626 & 6623 & & 5749 & 6192 \\
\hline 22 & & & & & & \\
\hline 23 & & 4375 & 4938 & 4867 & 5091 & 5002 \\
\hline 24 & & 4424 & 5895 & 5505 & 5770 & 5859 \\
\hline 25 & & 3155 & 5269 & 5093 & 4382 & 5029 \\
\hline 26 & & 5610 & 5625 & 6113 & 5561 & 5564 \\
\hline 27 & & & & & & \\
\hline 28 & & 4869 & 5049 & & 4751 & 5003 \\
\hline 29 & & & & & & \\
\hline 30 & & 6103 & 5921 & 5090 & 5043 & 5541 \\
\hline 32 & & 4355 & 5811 & 6298 & 5838 & 5791 \\
\hline 33 & & 3923 & 5601 & & 4106 & 5147 \\
\hline 34 & & 3669 & 5284 & 4558 & 4667 & 4890 \\
\hline 35 & & & & & & \\
\hline 36 & & 5275 & 6152 & & 5562 & 5961 \\
\hline 36 & & 18854.19 & 21989.54 & & 19879.5 & 21306.88 \\
\hline & & & & & & \\
\hline & Mean & 5243.177 & 6321.5 & 5697.744 & 5803.054 & 6122.217 \\
\hline & SD & 2872.91 & 3186.515 & 1388.97 & 2888.029 & 3066.738 \\
\hline & SE & 492.6999 & 546.4829 & 238.2065 & 495.2929 & 525.9413 \\
\hline
\end{tabular}


Fibre Area Post

\begin{tabular}{|c|c|c|c|c|c|c|}
\hline Subject & & $I$ & IIA & IIAX & IIX & II (Pooled) \\
\hline 1 & & 4692.528 & 5544.243 & \begin{tabular}{|l|}
4677.324 \\
\end{tabular} & 3953.704 & 4673.883 \\
\hline 2 & & 6155.062 & 7922.584 & & 8130.462 & 7964.16 \\
\hline 3 & & 5961.641 & 7394.555 & 7276.707 & 6748.678 & 7072.025 \\
\hline 4 & & 5631.392 & 7668.377 & 6095.328 & 6727.272 & 7481.758 \\
\hline 5 & & 4545.293 & 5771.071 & 6591.592 & 5548.001 & 5699.556 \\
\hline 6 & & 5498.226 & 7139.903 & & 6877.738 & 7133.094 \\
\hline 7 & & 5185.876 & 6881.439 & & 6414.86 & 6695.509 \\
\hline 9 & & 5413.067 & 7470.498 & & 7759.527 & 7521.205 \\
\hline 10 & & 7415.259 & 7967.109 & & & 7967.109 \\
\hline 11 & & & 6635.816 & 11274.37 & 6424.442 & 6475.913 \\
\hline 12 & & & 5430.574 & & 3872.905 & 4734.594 \\
\hline 13 & & 4371.394 & 7044.663 & & 7262.091 & 7127.38 \\
\hline 14 & & 5243.909 & 5937.485 & & 3904.334 & 5317.622 \\
\hline 15 & & 4319.452 & 6547.967 & 4636.919 & 5040.713 & 6145.21 \\
\hline 16 & & 5334.938 & 5890.455 & & 6822.006 & 6120.467 \\
\hline 17 & & 4659.849 & 5897.469 & 4089.479 & 4466.815 & 5534.469 \\
\hline 18 & & 3064.486 & 5167.612 & & 5792.924 & 5204.395 \\
\hline 19 & & 3981.307 & 5689.533 & 7136.327 & 5382.724 & 5582.689 \\
\hline 20 & & & & & & \\
\hline 21 & & 4866.452 & 7366.594 & 5919.905 & 5765.326 & 7098.885 \\
\hline 22 & & & & & & \\
\hline 23 & & 4591.494 & 6192.386 & 6502.26 & 6543.697 & 6290.422 \\
\hline 24 & & 4608.198 & 6059.38 & 5993.124 & 6081.505 & 6073.58 \\
\hline 25 & & 4196.936 & 6642.647 & 7403.029 & 6197.356 & 6496.386 \\
\hline 26 & & 5545.476 & 5918.269 & 5401.413 & 5156.512 & 5727.38 \\
\hline 27 & & & & & & \\
\hline 28 & & 4886.957 & 5261.208 & 4928.098 & 4756.549 & 5133.929 \\
\hline 29 & & & & & & \\
\hline 30 & & 6828.884 & 7782.029 & 6866.197 & 6032.45 & 6832.844 \\
\hline 32 & & 4262.782 & 6713.53 & 5595.964 & 4975.737 & 5827.997 \\
\hline 33 & & 3958.648 & 6152.753 & 6870.164 & 5504.522 & 5959.991 \\
\hline 34 & & 3959.505 & 5305.646 & & 5496.264 & 5335.601 \\
\hline 35 & & & & & & \\
\hline 36 & & 5475.966 & 7220.35 & & 6062.594 & 6813.227 \\
\hline & & & & & & \\
\hline & Mean & 4998.556 & 6538.282 & 6411.305 & 5916.593 & 6334.55 \\
\hline & $S D$ & 951.9691 & 859.8259 & 1618.762 & 1055.213 & 880.4439 \\
\hline & SE & 163.2614 & 147.4589 & 277.6153 & 180.9676 & 150.9949 \\
\hline
\end{tabular}


Type 1 Fibre Area ANOVA Pre vs Post

\begin{tabular}{|c|c|c|c|c|c|}
\hline & SS & Degr. of & MS & F & P \\
\hline Group & $1.377494 \mathrm{E}+07$ & 2 & $6.887470 \mathrm{E}+06$ & 6.031 & 0.006836 \\
\hline Error & $3.083561 \mathrm{E}+07$ & 27 & $1.142059 \mathrm{E}+06$ & & \\
\hline TIME & $3.320723 \mathrm{E}+05$ & 1 & $3.320723 \mathrm{E}+05$ & 2.074 & 0.161317 \\
\hline TIME*Group & $2.450979 \mathrm{E}+05$ & 2 & $1.225489 \mathrm{E}+05$ & 0.765 & 0.474967 \\
\hline Error & $4.322875 \mathrm{E}+06$ & 27 & $1.601065 \mathrm{E}+05$ & & \\
\hline
\end{tabular}

Type II Fibre Area ANOVA Pre vs. Post

\begin{tabular}{|c|c|c|c|c|c|}
\hline & \multicolumn{1}{|c|}{ SS } & Degr. of & \multicolumn{1}{c|}{ MS } & F & P \\
\hline "Var1" & $9.388842 \mathrm{E}+06$ & 2 & $4.694421 \mathrm{E}+06$ & 3.424 & 0.047283 \\
\hline Error & $3.701767 \mathrm{E}+07$ & 27 & $1.371025 \mathrm{E}+06$ & & \\
\hline TIME & $5.640096 \mathrm{E}+06$ & 1 & $5.640096 \mathrm{E}+06$ & 16.043 & 0.000436 \\
\hline TIME ${ }^{\star 1 V a r 1 "}$ & $1.280662 \mathrm{E}+06$ & 2 & $6.403309 \mathrm{E}+05$ & 1.821 & 0.181129 \\
\hline Error & $9.492250 \mathrm{E}+06$ & 27 & $3.515648 \mathrm{E}+05$ & & \\
\hline
\end{tabular}

Type II fibre area ANCOVA Pre vs. Post, Pre fibre size as covariate

\begin{tabular}{|c|c|c|c|c|c|c|}
\hline & df Effect & MS Effect & df Error & MS Error & $\mathbf{F}$ & p-level \\
\hline 1 & 2 & 96671 & 25 & 167824.9 & 0.57602 & 0.569416 \\
\hline 2 & 1 & 7788961 & 26 & 177610.0 & 43.85430 & 0.000001 \\
\hline 12 & 2 & 274659 & 26 & 177610.0 & 1.54642 & 0.231971 \\
\hline
\end{tabular}

Type II fibre area gains one way ANOVA

\begin{tabular}{|l|c|c|c|c|c|}
\hline & SS & Degr. of & MS & F & p \\
\hline Intercept & 15577922 & 1 & 15577922 & 43.85430 & 0.000001 \\
\hline "Var1" & 1098638 & 2 & 549319 & 1.54642 & 0.231971 \\
\hline Error & 9235718 & 26 & 355220 & & \\
\hline
\end{tabular}




\section{APPENDIX 5}

\% FIBRE DISTRIBUTION RAW DATA AND ANOVA TABLES 
\% Fibre distribution Pre

\begin{tabular}{|c|c|c|c|c|}
\hline Subject & & 1 & IIA & IIX \\
\hline 1 & & 38.80 & 33.35 & 27.85 \\
\hline 2 & & 46.76 & 29.46 & 23.77 \\
\hline 3 & & 49.99 & 18.87 & 31.15 \\
\hline 4 & & 35.84 & 35.77 & 28.39 \\
\hline 5 & & 28.42 & 50.92 & 20.66 \\
\hline 6 & & 37.26 & 55.48 & 7.25 \\
\hline 7 & & 64.78 & 15.60 & 19.62 \\
\hline 9 & & 40.62 & 33.59 & 25.79 \\
\hline 10 & & 23.13 & 39.90 & 36.97 \\
\hline 11 & & 56.62 & 23.07 & 20.30 \\
\hline 12 & & 29.81 & 46.33 & 23.86 \\
\hline 13 & & 18.22 & 46.43 & 35.35 \\
\hline 14 & & 21.08 & 47.42 & 31.50 \\
\hline 15 & & 30.17 & 39.06 & 30.77 \\
\hline 16 & & 40.67 & 36.48 & 22.85 \\
\hline 17 & & 24.02 & 53.39 & 22.60 \\
\hline 18 & & 45.87 & 33.40 & 20.74 \\
\hline 19 & & 37.01 & 58.18 & 4.82 \\
\hline 20 & & & & \\
\hline 21 & & 47.99 & 30.26 & 21.75 \\
\hline 22 & & & & \\
\hline 23 & & 19.66 & 48.69 & 31.65 \\
\hline 24 & & 31.71 & 46.47 & 21.82 \\
\hline 25 & & 34.48 & 52.71 & 12.81 \\
\hline 26 & & 31.26 & 31.22 & 37.52 \\
\hline 27 & & & & \\
\hline 28 & & 27.23 & 53.15 & 19.62 \\
\hline 29 & & 39.07 & 39.10 & 21.83 \\
\hline 30 & & & & \\
\hline 32 & & 25.35 & 55.68 & 18.98 \\
\hline 33 & & 37.38 & 37.95 & 24.68 \\
\hline 34 & & 40.15 & 25.50 & 34.35 \\
\hline 35 & & & & \\
\hline 36 & & 45.44 & 38.09 & 16.47 \\
\hline & & & & \\
\hline & Mean & 36.06975 & 40.07756 & 23.85268 \\
\hline & SD & 11.30033 & 11.62443 & 8.092878 \\
\hline & $\mathrm{SE}$ & 1.937991 & 1.993574 & 1.387917 \\
\hline
\end{tabular}


\% Fibre distribution Post

\begin{tabular}{|c|c|c|c|c|}
\hline Subject & & 1 & IIA & IIX \\
\hline 1 & & 44.15 & 30.58 & 25.28 \\
\hline 2 & & 46.66 & 39.56 & 13.78 \\
\hline 3 & & 41.81 & 33.65 & 24.54 \\
\hline 4 & & 44.36 & 45.17 & 10.48 \\
\hline 5 & & 34.18 & 50.11 & 15.71 \\
\hline 6 & & 27.67 & 70.52 & 1.81 \\
\hline 7 & & 35.85 & 47.17 & 16.98 \\
\hline 9 & & 54.01 & 38.57 & 7.42 \\
\hline 10 & & 48.21 & 51.79 & \\
\hline 11 & & 44.65 & 32.74 & 22.61 \\
\hline 12 & & 37.04 & 39.95 & 23.01 \\
\hline 13 & & 39.02 & 37.34 & 23.64 \\
\hline 14 & & 38.48 & 45.13 & 16.40 \\
\hline 15 & & 23.50 & 56.44 & 20.06 \\
\hline 16 & & 52.81 & 34.20 & 12.99 \\
\hline 17 & & 26.65 & 58.00 & 15.35 \\
\hline 18 & & 28.73 & 66.64 & 4.64 \\
\hline 19 & & 48.35 & 40.58 & 11.08 \\
\hline 20 & & & & \\
\hline 21 & & 43.00 & 48.50 & 8.50 \\
\hline 22 & & & & \\
\hline 23 & & 18.13 & 58.88 & 22.99 \\
\hline 24 & & 15.81 & 58.12 & 26.07 \\
\hline 25 & & 38.14 & 50.90 & 10.95 \\
\hline 26 & & 33.30 & 48.46 & 18.24 \\
\hline 27 & & & & \\
\hline 28 & & 34.97 & 47.10 & 17.92 \\
\hline 29 & & 43.64 & 47.97 & 8.40 \\
\hline 30 & & & & \\
\hline 32 & & 36.74 & 39.54 & 23.72 \\
\hline 33 & & 24.95 & 59.18 & 15.87 \\
\hline 34 & & 37.22 & 44.88 & 17.90 \\
\hline 35 & & & & \\
\hline 36 & & 49.05 & 35.01 & 15.94 \\
\hline & & & & \\
\hline & Mean & 37.39 & 47.36 & 15.81 \\
\hline & SD & 9.95 & 9.96 & 6.43 \\
\hline & $S E$ & 1.71 & 1.71 & 1.10 \\
\hline
\end{tabular}


Type $1 \%$ Distribution ANOVA Pre vs Post

\begin{tabular}{|c|c|c|c|c|c|}
\hline & SS & Degr. of & MS & F & P \\
\hline "Var1" & 0.083234 & 2 & 0.041617 & 3.2954 & 0.053019 \\
\hline Error & 0.328356 & 26 & 0.012629 & & \\
\hline TIME & 0.003369 & 1 & 0.003369 & 0.4273 & 0.519038 \\
\hline TIME*"Var1" & 0.000694 & 2 & 0.000347 & 0.0440 & 0.956978 \\
\hline Error & 0.204961 & 26 & 0.007883 & & \\
\hline
\end{tabular}

Type IIA \% Distribution ANOVA Pre vs. Post

\begin{tabular}{|c|c|c|c|c|c|}
\hline & Ss & Degr. of & MS & $\mathbf{F}$ & $\mathbf{p}$ \\
\hline "Var1" & 0.117921 & 2 & 0.058961 & 2.7822 & 0.080369 \\
\hline Error & 0.550997 & 26 & 0.021192 & & \\
\hline TIME & 0.045153 & 1 & 0.045153 & 5.4902 & 0.027048 \\
\hline TIME" "Var1" & 0.001925 & 2 & 0.000962 & 0.1170 & 0.890025 \\
\hline Error & 0.213830 & 26 & 0.008224 & & \\
\hline
\end{tabular}

Type IIX \% Distribution ANOVA Pre vs. Post

\begin{tabular}{|c|c|c|c|c|c|}
\hline & SS & Degr. of & MS & F & P \\
\hline "Var1" & 0.013480 & 2 & 0.006740 & 0.4249 & 0.658498 \\
\hline Error & 0.396601 & 25 & 0.015864 & & \\
\hline R1 & 0.053147 & 1 & 0.053147 & 9.9661 & 0.004129 \\
\hline R1 $^{* \text { "Var1" }}$ & 0.001295 & 2 & 0.000647 & 0.1214 & 0.886213 \\
\hline Error & 0.133321 & 25 & 0.005333 & & \\
\hline
\end{tabular}




\section{APPENDIX 6}

BLOOD GLUCOSE CONCENTRATIONS RAW DATA AND ANOVA TABLES 
Blood Glucose Concentration Following Exercise bout and Supplement Consumption

\begin{tabular}{|c|c|c|c|c|c|c|}
\hline $\begin{array}{l}\text { Subject } \\
\#\end{array}$ & Pre & Post & 30 & 60 & 90 & 120 \\
\hline 1 & 4.49 & 3.96 & 5.58 & 4.44 & 4.28 & 4.42 \\
\hline 2 & 4.41 & 4.42 & & 3.09 & 5.19 & 3.27 \\
\hline 3 & 3.81 & 4 & 5.93 & 3.06 & 4.22 & 3.74 \\
\hline 4 & 4.19 & 4.65 & 7.02 & 4.61 & 4.58 & 3.84 \\
\hline 5 & 4.34 & 3.88 & 7.71 & 5.12 & 5.8 & \\
\hline 6 & 4.12 & 3.38 & 4.74 & 4.28 & 2.81 & 3.71 \\
\hline 7 & 3.77 & 4.13 & 6.75 & 5.13 & 3.5 & 3.96 \\
\hline 9 & 3.71 & 3.61 & 6.39 & 3.36 & 4.17 & 3.55 \\
\hline 10 & 4.56 & 4.7 & 9.84 & 2.95 & 7.48 & 6.64 \\
\hline 11 & 4.24 & 3.98 & 5.96 & 3.11 & 4.71 & 3.56 \\
\hline 12 & 4.46 & 4 & 4.99 & 3.89 & 4.2 & 4.25 \\
\hline 13 & 3.75 & 3.25 & 3.82 & 2.98 & 3.03 & 2.98 \\
\hline 14 & 5.13 & 3.97 & 4.48 & 3.73 & 3.56 & 4.02 \\
\hline 15 & 4.18 & 3.68 & 3.81 & 2.84 & 3.77 & 2.57 \\
\hline 16 & 6.93 & 4.84 & 4.6 & 3.7 & 5.51 & 3.69 \\
\hline 17 & 6.87 & 3.93 & 4.42 & 2.97 & 3.88 & 3.07 \\
\hline 18 & 4.37 & 4.1 & 5.99 & 3.67 & 5.11 & 3.88 \\
\hline 19 & 3.97 & 3.96 & 4.28 & 2.29 & 3.94 & 3.14 \\
\hline 20 & 3.34 & 4.04 & 4.1 & 4.06 & 3 & 3.81 \\
\hline 21 & 4.88 & 4.2 & 4.4 & 3.42 & 3.61 & 4.08 \\
\hline 22 & 4.44 & 4.01 & 4.66 & 3.49 & 3.98 & 3.48 \\
\hline 23 & 4.04 & 4.06 & 3.42 & 3.55 & 4.1 & 3.41 \\
\hline 24 & 4.32 & 4.1 & 4.55 & 3.56 & 4.91 & 3.96 \\
\hline 25 & 2.91 & 3.76 & 3.46 & 3.24 & 4.03 & 3.18 \\
\hline 26 & 4.07 & 4.07 & 3.71 & 3.47 & 4.82 & 3.54 \\
\hline 27 & 4.34 & 4.34 & 4.34 & 3.84 & 4.75 & 4.33 \\
\hline 28 & 5.75 & 4.93 & 3.94 & 4.11 & 3.74 & 4.06 \\
\hline 29 & 4.51 & 4.64 & 6 & 3.9 & 4.57 & 4.09 \\
\hline 30 & 3.68 & 3.76 & 3.99 & 3.33 & 4.1 & 3.45 \\
\hline 32 & 4.76 & 4.39 & 4.96 & 3.15 & 4.09 & 3.73 \\
\hline 33 & 3.84 & 4.09 & 4.63 & 4.32 & 4.66 & 4.17 \\
\hline 34 & 5.47 & 4.02 & 5.34 & 3.89 & 4.78 & 4.1 \\
\hline 35 & 4.19 & 3.9 & 4.23 & 3.1 & 3.06 & 3.28 \\
\hline 36 & 4.71 & 4.56 & 4.26 & 3.19 & 4.1 & 2.99 \\
\hline & & & & & & \\
\hline Mean & 4.426061 & 4.101515 & 5.0225 & 3.587879 & 4.295758 & 3.735313 \\
\hline SD & 0.84736 & 0.385463 & 1.388322 & 0.630034 & 0.915082 & 0.67963 \\
\hline SE & 0.145321 & 0.066106 & 0.238095 & 0.10805 & 0.156935 & 0.116556 \\
\hline
\end{tabular}


Glucose ANOVA for all time points

\begin{tabular}{|c|c|c|c|c|c|}
\hline & SS & Degr. of & MS & F & p \\
\hline group & 8.661 & 2 & 4.330 & 2.973 & 0.066893 \\
\hline Error & 42.236 & 29 & 1.456 & & \\
\hline Time & 41.031 & 5 & 8.206 & 21.253 & 0.000000 \\
\hline Time ${ }^{\star}$ group & 22.319 & 10 & 2.232 & 5.780 & 0.000000 \\
\hline Error & 55.988 & 145 & 0.386 & & \\
\hline
\end{tabular}

Tukey Post Hoc

Calculated by hand

Critical Value $=$ SRS * $($ SQRT $($ MSERROR $/$ \# of OBSERVATIONS Per Mean $))$

SRS for 5 means and $120 \mathrm{df}=3.98$

CV $=3.98 *($ SQRT $(0.56451 / 11))$

$\mathrm{CV}=0.9$

Blood Glucose Concentrations

\begin{tabular}{|c|c|c|c|}
\hline & CON & MLK & PEC \\
\hline Pre & $4.19 \pm 0.09$ & $4.69 \pm 0.33$ & $4.38 \pm 0.24$ \\
\hline $0(\mathrm{mmol} / \mathrm{L})$ & $4.06 \pm 0.12$ & $4.01 \pm 0.10$ & $4.22 \pm 0.11$ \\
\hline $30(\mathrm{mmol} / \mathrm{L})$ & $6.49 \pm 0.479^{*}$ & $4.38 \pm 0.18$ & $4.44 \pm 0.23$ \\
\hline $60(\mathrm{mmol} / \mathrm{L})$ & $3.91 \pm 0.25$ & $3.36 \pm 0.14$ & $3.59 \pm 0.13$ \\
\hline $90(\mathrm{mmol} / \mathrm{L})$ & $4.63 \pm 0.37$ & $4.03 \pm 0.23$ & $4.25 \pm 0.16$ \\
\hline $120(\mathrm{mmol} / \mathrm{L})$ & $4.09 \pm 0.30$ & $3.51 \pm 0.14$ & $3.72 \pm 0.14$ \\
\hline
\end{tabular}

Results are Mean \pm SEM

*Significantly different from $0(\mathrm{P}<0.05)$,

qSignificantly higher than MLK and PEC at same time point $(\mathrm{P}<0.05)$ 


\section{APPENDIX 7}

BLOOD INSULIN CONCENTRATIONS RAW DATA AND ANOVA TABLES 
Blood Insulin Concentration Following Exercise and Supplement Consumption

\begin{tabular}{|r|r|r|r|r|}
\hline Subject & POST & 30 & 60 & 120 \\
\hline 1 & 7.41989 & 81.08067 & 46.42544 & 76.36851 \\
\hline 2 & 5.928155 & 81.88126 & 11.99006 & 16.8748 \\
\hline 3 & 4.5482 & 22.66662 & 9.292703 & 8.920859 \\
\hline 4 & 7.193318 & 73.7416 & 45.04928 & 44.3902 \\
\hline 5 & 4.16072 & 25.03755 & 12.67528 & \\
\hline 6 & 4.961092 & 19.8448 & 19.06828 & 22.46568 \\
\hline 7 & 4.579464 & 39.02763 & 36.05925 & 19.76047 \\
\hline 9 & 4.831297 & 23.83654 & 7.131408 & 15.47466 \\
\hline 10 & 20.05233 & 117.4839 & 89.22261 & 120.2398 \\
\hline 11 & & 44.88347 & 9.044604 & 15.20789 \\
\hline 12 & & & & \\
\hline 13 & 8.345297 & 19.18289 & 10.92889 & 9.090982 \\
\hline 14 & 5.790235 & 21.76973 & 9.52573 & 10.55532 \\
\hline 15 & 3.053115 & 21.24178 & 4.552995 & 6.775833 \\
\hline 16 & 6.535763 & 17.10632 & 5.59524 & 6.587804 \\
\hline 17 & 7.248184 & 37.15995 & 7.731319 & 14.46104 \\
\hline 18 & 3.619874 & 35.16587 & 5.339072 & 4.539557 \\
\hline 19 & 10.9717 & 73.15644 & 14.10068 & 13.68503 \\
\hline 20 & 5.754802 & 9.950526 & & 9.847041 \\
\hline 21 & 4.137876 & 57.23146 & 6.000555 & 13.28641 \\
\hline 22 & 12.91802 & 47.68866 & 13.22906 & 12.70557 \\
\hline 23 & 8.064384 & 24.12768 & 8.742603 & 9.847041 \\
\hline 24 & 5.133348 & 18.60524 & 12.55079 & 8.029573 \\
\hline 25 & 8.546286 & 18.9573 & 12.11076 & 9.993664 \\
\hline 26 & 7.059809 & 26.87772 & 7.365651 & 10.75371 \\
\hline 27 & 7.016185 & 30.54432 & 7.511244 & 6.746827 \\
\hline 28 & 15.33575 & 36.7744 & 11.36324 & 13.14718 \\
\hline 29 & & & & \\
\hline 30 & 6.913938 & 41.53286 & 14.10702 & 19.50393 \\
\hline 32 & 4.823469 & 22.80325 & 15.30025 & 11.62844 \\
\hline 33 & 5.446974 & 7.375872 & 5.819326 & 4.602952 \\
\hline 34 & 6.460531 & 50.01159 & 7.964705 & 6.549868 \\
\hline 35 & 5.16895 & 85.55268 & 15.53551 & 23.69599 \\
\hline 36 & 15.30414 & 65.17043 & 8.56562 & 12.307 \\
\hline & & & & \\
\hline & & & & \\
\hline SD & 7.330107 & 39.2384 & 14.78246 & 16.7225 \\
\hline & 3.914702 & 25.63988 & 16.45022 & 21.00279 \\
\hline & & & & \\
\hline 6.671366 & 4.397204 & 2.821189 & 3.601948 \\
\hline
\end{tabular}


Insulin ANOVA for all time points

\begin{tabular}{|c|c|c|c|c|c|}
\hline & SS & Degr. of & MS & F & p \\
\hline group & 7631.26 & 2 & 3815.63 & 5.04446 & 0.012687 \\
\hline Error & 23448.39 & 31 & 756.40 & & \\
\hline TIME & 20940.87 & 3 & 6980.29 & 46.71352 & 0.000000 \\
\hline TIME* group & 3073.33 & 6 & 512.22 & 3.42789 & 0.004212 \\
\hline Error & 13896.77 & 93 & 149.43 & & \\
\hline
\end{tabular}

\section{Tukey Post Hoc}

\section{Calculated by hand}

\section{Critical Value $=$ SRS * $($ SQRT $($ MSERROR $/$ \# of OBSERVATIONS Per Mean))}

Studentized range statistic (SRS) for 4 means, $80 \mathrm{df}:=3.74$

Critical Value = 3.74 $($ SQRT $(301.17 / 11)$

$\mathrm{CV}=\mathbf{1 9 . 5}$

Insulin Means

\begin{tabular}{|c|c|c|c|}
\hline & CON & MLK & PEC \\
\hline $0(\mu \mathrm{lU} / \mathrm{mL})$ & 7.1 & 6.8 & 8.2 \\
\hline $30(\mu \mathrm{lU} / \mathrm{mL})$ & $52.9 \pm^{*}$ & $31.9^{*}$ & $38.6^{*}$ \\
\hline $60(\mu \mathrm{lU} / \mathrm{mL})$ & $28.6 q^{*}$ & 8.9 & 10.6 \\
\hline $120(\mu \mathrm{lU} / \mathrm{mL})$ & $37.7 q^{*}$ & 10.0 & 11.9 \\
\hline
\end{tabular}

*Significantly different from $0(\mathrm{P}<0.05)$

ISignificantly higher than MLK and PEC at same time point $(\mathrm{P}<0.05)$

\pm Significantly higher that $\mathrm{MLK}$ at same time point $(\mathrm{P}<0.05)$ 
APPENDIX 8

CORRELATIONS 
Correlation: Lean Mass Gains and Mean $\mathrm{kcal} / \mathrm{kg}$ during training

Scatterplot: Mean kcal/d vs. Lean Gain (Casewise MD deletion)

Lean Gain $=1.3068+.44 \mathrm{E}-3$ * Mean $\mathrm{kcal} / \mathrm{d}$

Correlation: $r=.20306$

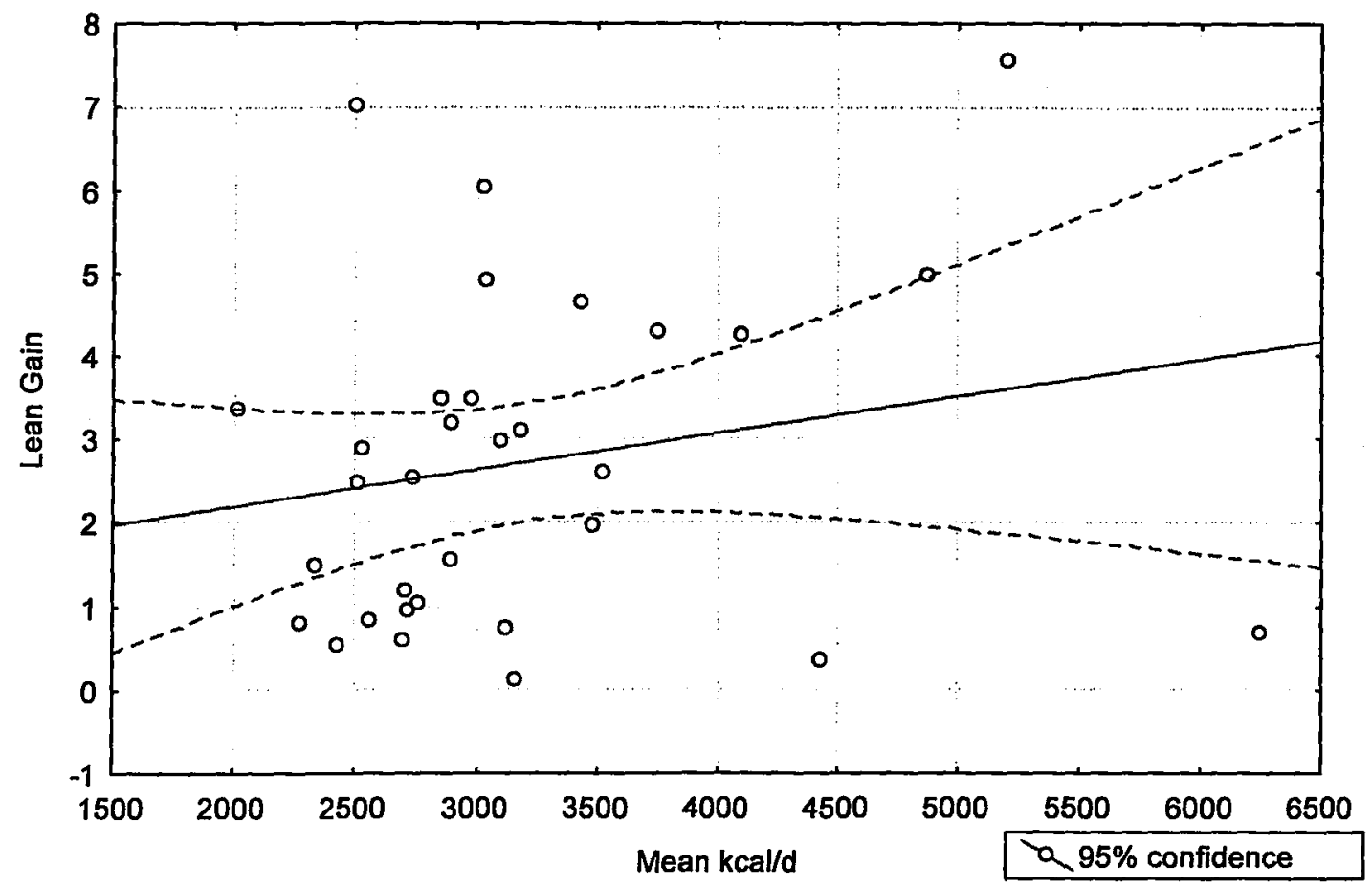

Correlation not significant $(\mathrm{P}>0.05)$ 
Correlation: Lean Mass Gains and Mean Protein intake during training

Scatterplot: Mean PRO vs. Lean Gain (Casewise MD deletion)

Lean Gain $=2.1012+.00453 *$ MeanPRO

Correlation: $r=.08868$

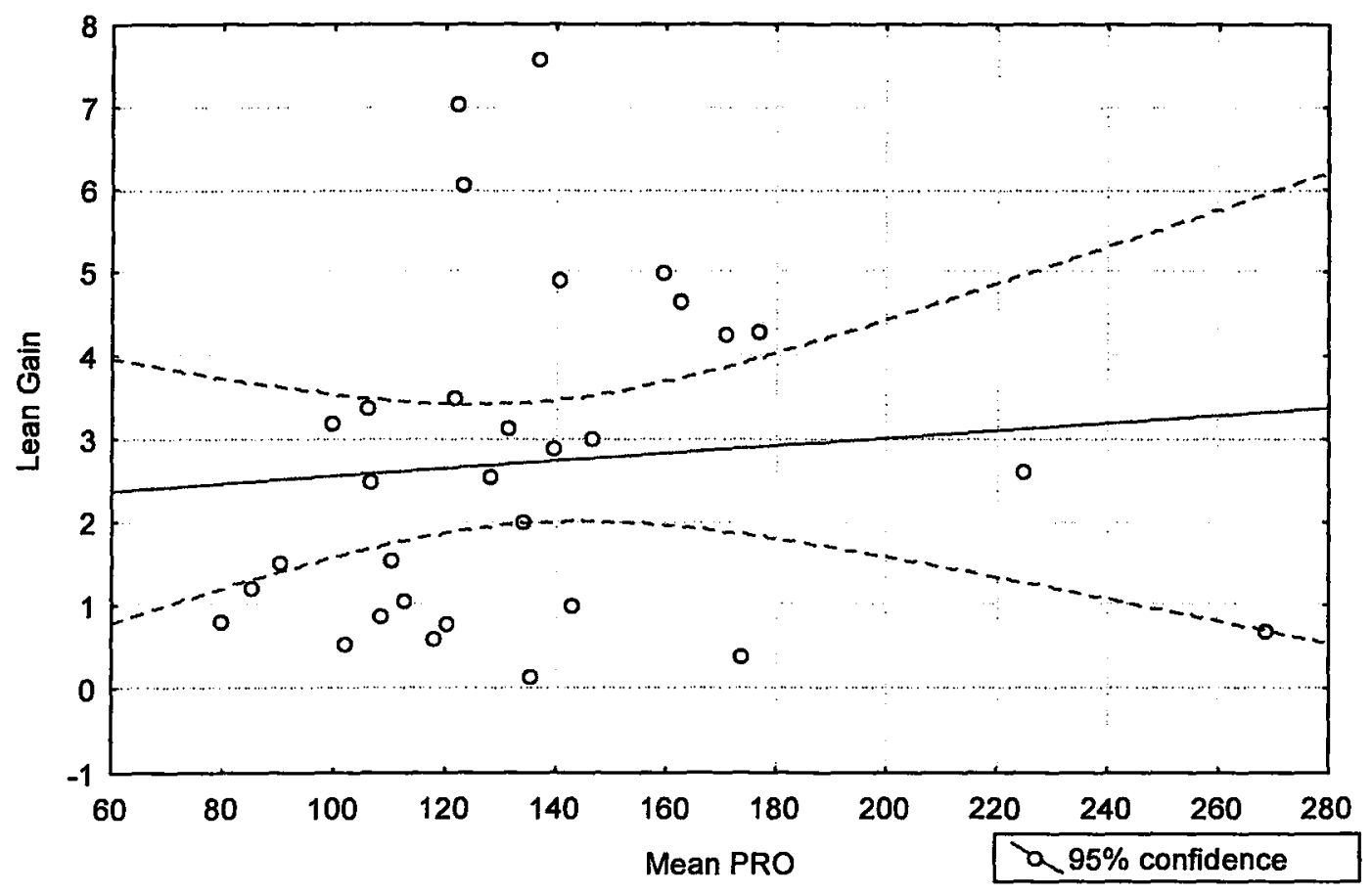

Correlation not significant $(\mathrm{P}>0.05)$ 
Correlation: Lean Mass Gains and Mean Protein/kg intake during training

Scatterplot: Mean Pro/kg vs. Lean Gain (Casewise MD deletion)

Lean Gain $=2.9623-.1532 *$ Mean Pro/kg

Correlation: $r=-.0443$

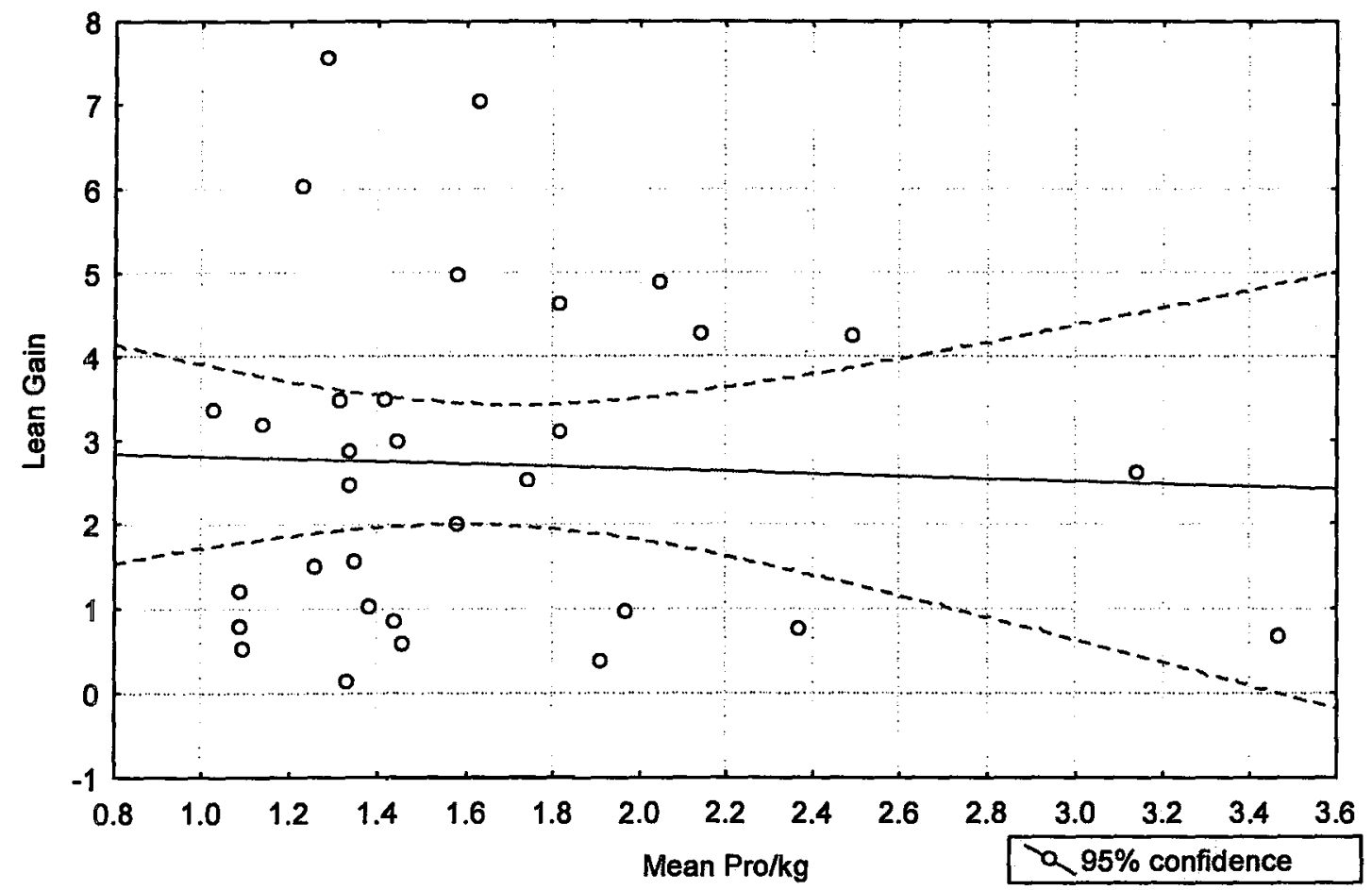

Correlation not significant $(\mathrm{P}>0.05)$ 
Correlation: Lean Mass Gains and Bench Press Strength Gains

Scatterplot: bench pre gain vs. Lean Gain (Casewise MD deletion)

Lean Gain $=.66200+.02415 *$ bench pre gain

Correlation: $r=.24937$

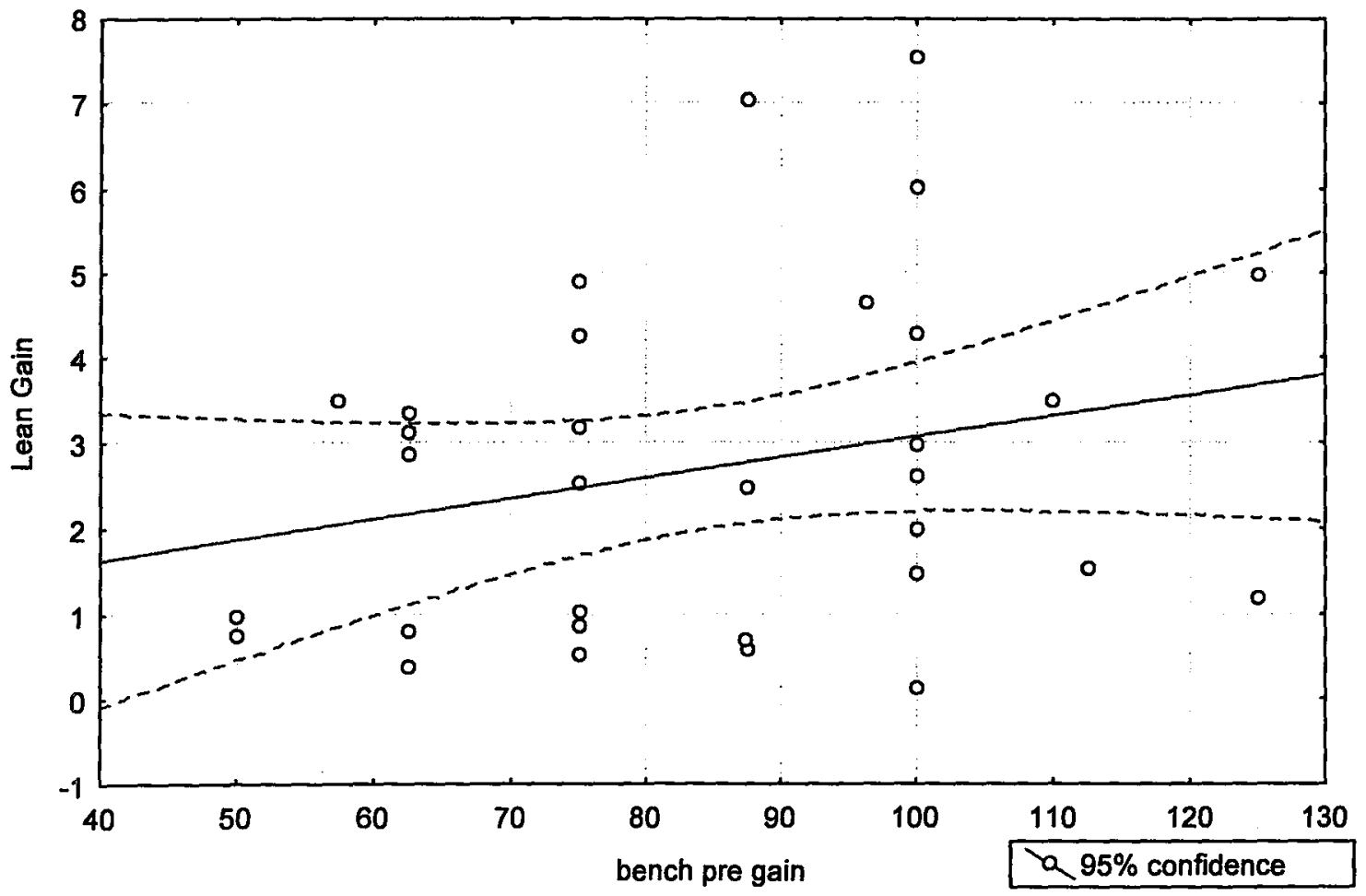

Correlation not significant $(\mathrm{P}>0.05)$ 
Correlation: Lean Mass Gains and Leg Press Strength Gains

Scatterplot: Leg press gain vs. Lean Gain (Casewise MD deletion)

Lean Gain $=.83176+.00447 *$ Leg press gain

Correlation: $r=.49151$

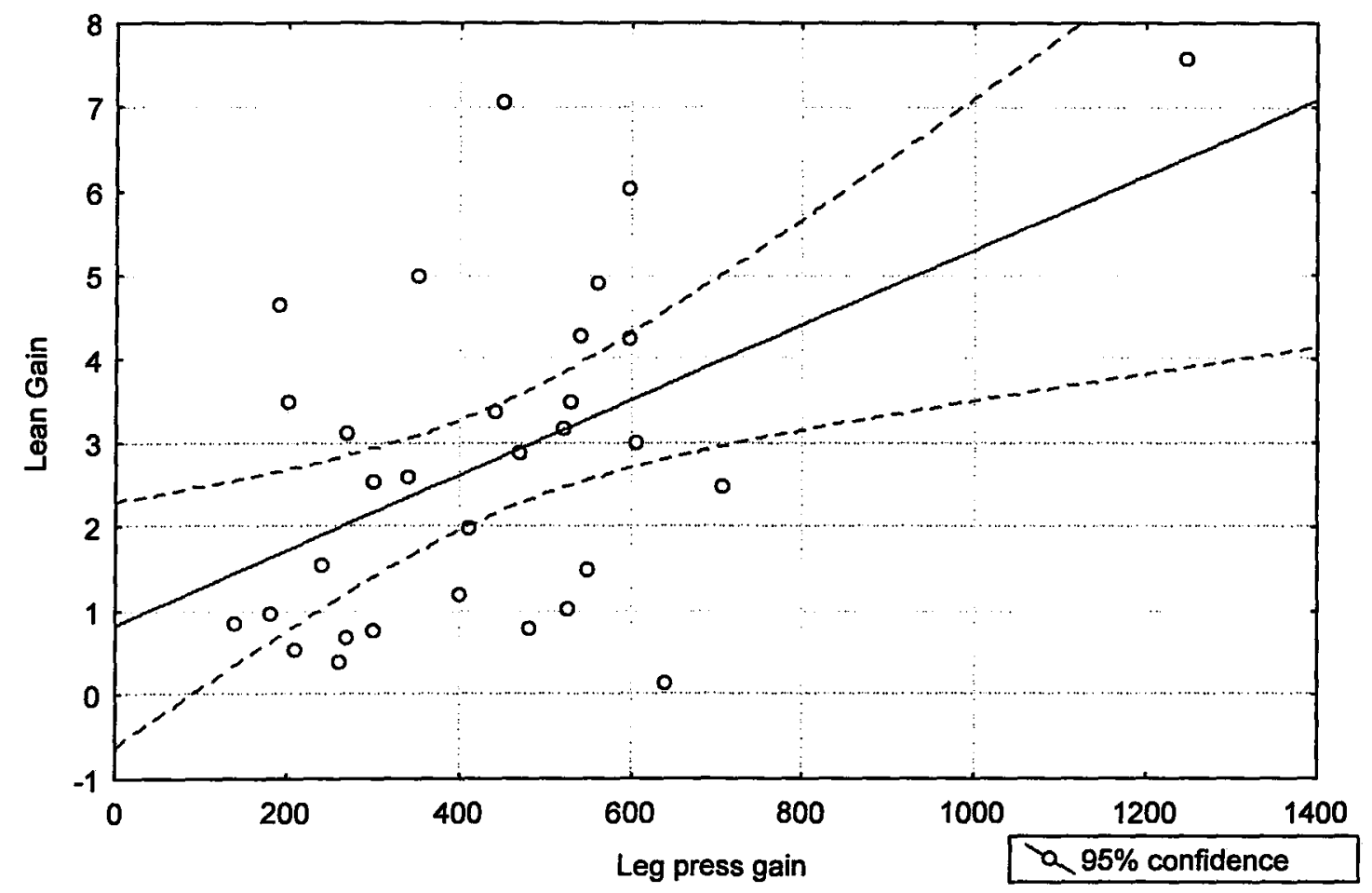

Correlation significant $(\mathrm{P}<0.05)$ 
Correlation: Lean Mass Gains and Training Volume

Scatterplot: Training volume vs. Lean Gain (Casewise MD deletion)

Lean Gain $=2.3994+.23 E-4 *$ Training volume

Correlation: $r=.02454$

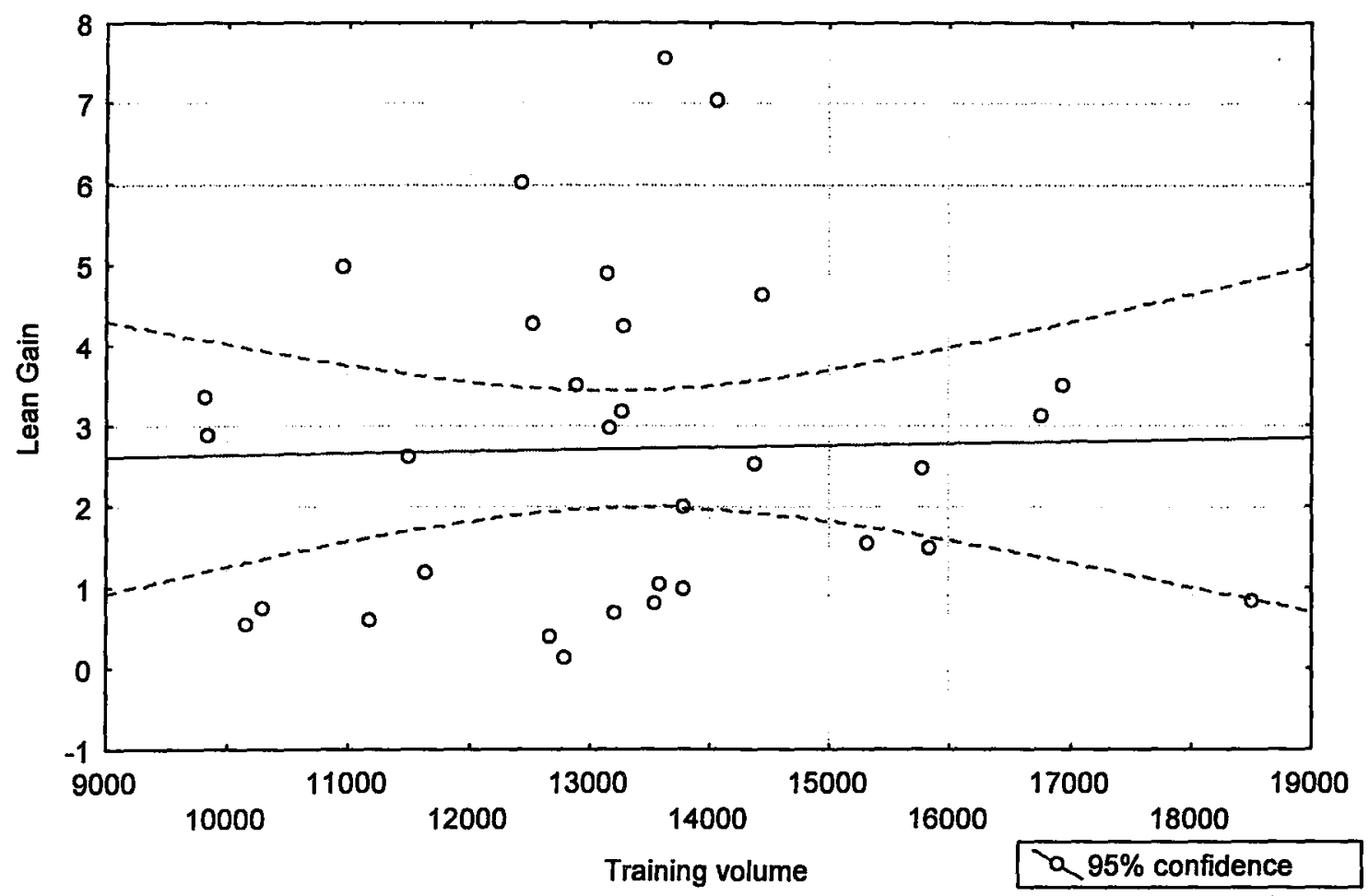

Correlation not significant $(\mathrm{P}>0.05)$ 
APPENDIX 9

DRINK COMPOSITIONS 
Drink Compostitions

\begin{tabular}{|c|c|c|c|}
\hline & CON & MLK & PEC \\
\hline Protein (g) & 0 & 18.2 & 18.2 \\
\hline Carbohydrate (g) & 45 & 24.5 & 22.9 \\
\hline Fat (g) & 0 & 1.0 & 1.6 \\
\hline Total kcal & 180 & 180.1 & 179 \\
\hline
\end{tabular}


APPENDIX 10

AA COMPOSTION OF MILK AND SOY PROTEINS 
AA Composition of Soy and Milk Proteins

\begin{tabular}{|l|c|c|c|c|}
\hline & SOY & $\%$ & MILK & $\%$ \\
\hline & $\begin{array}{c}(\mathrm{mg} / \mathrm{g} \\
\text { PRO) }\end{array}$ & & $\begin{array}{c}(\mathrm{mg} / \mathrm{g} \\
\text { PRO) }\end{array}$ & \\
\hline ASP & 56 & 7.2 & 51 & 5.6 \\
\hline SER & 81 & 10.5 & 87 & 9.6 \\
\hline ASN & & & & \\
\hline GLU & 120 & 15.5 & 189 & 20.8 \\
\hline GLY & 29 & 3.7 & 18 & 2.0 \\
\hline GLN & & & & \\
\hline HIS & 22 & 2.8 & 24 & 2.6 \\
\hline TAU & & & & \\
\hline THR & 61 & 7.9 & 69 & 7.6 \\
\hline ARG & 51 & 6.5 & 29 & 3.2 \\
\hline ALA & 39 & 5.0 & 31 & 3.4 \\
\hline PRO & 50 & 6.5 & 83 & 9.1 \\
\hline TYR & 19 & 2.4 & 27 & 2.9 \\
\hline CYS & & & & \\
\hline VAL & 31 & 4.0 & 55 & 6.0 \\
\hline MET & 14 & 1.8 & 23 & 2.6 \\
\hline ILE & 42 & 5.4 & 43 & 4.7 \\
\hline LEU & 66 & 8.5 & 80 & 8.8 \\
\hline LYS & 51 & 6.6 & 60 & 6.6 \\
\hline PHE & 44 & 5.7 & 41 & 4.5 \\
\hline EAA & 329 & & 396 & \\
\hline TOTAL & 773 & & 912 & \\
\hline BCAA & 139 & & 178 & \\
\hline
\end{tabular}


APPENDIX 11

ATPase HISTOCHEMISTRY PROTOCOL 


\section{ATPASE HISTOCHEMICAL ANALYSIS}

Reference: Dubowitz, V. Muscle Biopsy: A practical approach 2ed. London: Bailliere Tindall, 1985.

Adapted by: Snow, R.J. School of Health Sciences, Deakin University, Australia

\section{PART A: CUTTING MUSCLE}

1. Store OCT mounted muscle at $-80^{\circ} \mathrm{C}$.

2. Prior to cutting muscle, place mounted muscle in cryostat for at least $15 \mathrm{~min}$ to reach $-20^{\circ} \mathrm{C}$.

3. Trim the OCT covered portion of the sample at $20 \mu \mathrm{m} /$ cut. Once muscle sample is exposed, reduce thickness of cut to $10 \mu \mathrm{m}$ for ATPase stain.

4. Cut 2-3 samples per slide.

5. Cover slides with paper towel and allow slides to dry overnight at $4^{\circ} \mathrm{C}$.

6. Once dried, wrap slides in aluminum foil and store at $-80^{\circ} \mathrm{C}$ until further analysis.

\section{PART B: $\quad$ PREPARATION OF SOLUTIONS}

\section{Alkaline Stock Solution, pH 9.4}

\begin{tabular}{|c|l|l|l|}
\hline & \multicolumn{1}{|c|}{ Reagent } & \multicolumn{1}{|c|}{ Manufacturer } & \multicolumn{1}{c|}{ Qty } \\
\hline 1 & Glycine & BioShop Biotechnology Grade - GLN 001 & $2.8163 \mathrm{~g}$ \\
\hline 2 & $\mathrm{CaCl} 2 \mathrm{H}_{2} \mathrm{O}$ & BDH 10070/EM Science 10070-34 & $3.00 \mathrm{~g}$ \\
\hline 3 & $\mathrm{NaCl}$ & BioShop Reagent Grade - SOD 002 & $2.1938 \mathrm{~g}$ \\
\hline 4 & $\mathrm{NaOH}$ & BDH Analytical Reagent ACS 816 & $1.3500 \mathrm{~g}$ \\
\hline 5 & $\mathrm{MilliQ} \mathrm{H}_{2} \mathrm{O}$ & & $500 \mathrm{~mL}$ \\
\hline
\end{tabular}

1. Dissolve reagents in MilliQ $\mathrm{H}_{2} \mathrm{O}$ and bring to volume.

2. Calibrate $\mathrm{pH}$ meter prior to adjusting $\mathrm{pH}$ to 9.4 with conc. $\mathrm{HCl} / 5 \mathrm{M} \mathrm{KOH}$.

3. Store stock solution in fridge $\left(4^{\circ} \mathrm{C}\right)$.

Acid Preincubation Stock Solution, pH 4.6

\begin{tabular}{|c|l|l|l|}
\hline & \multicolumn{1}{|c|}{ Reagent } & Manufacturer & \multicolumn{1}{c|}{ Qty } \\
\hline 1 & Potassium Acetate & EM PX 1330-1 & $2.45 \mathrm{~g}$ \\
\hline 2 & $\mathrm{CaCl}_{2} \cdot 2 \mathrm{H}_{2} \mathrm{O}$ & BDH $10070 /$ EM Science $10070-34$ & $1.30 \mathrm{~g}$ \\
\hline 3 & $\mathrm{MilliQ}_{2} \mathrm{O}$ & & $500 \mathrm{~mL}$ \\
\hline
\end{tabular}

1. Dissolve reagents in MilliQ $\mathrm{H}_{2} \mathrm{O}$ and bring to volume.

2. Calibrate $\mathrm{pH}$ meter prior to adjusting $\mathrm{pH}$ to 4.6 with glacial acetic acid.

3. Store stock solution in fridge $\left(4^{\circ} \mathrm{C}\right)$. 
$5 \mathrm{M} \mathrm{NaOH}$ (MW: $40.00 \mathrm{~g} / \mathrm{mol}$ ) - Dissolve $20.00 \mathrm{~g}$ in $100 \mathrm{~mL}$ $5 \mathrm{M} \mathrm{KOH}$ (MW: $56.11 \mathrm{~g} / \mathrm{mol}$ ) - Dissolve $28.055 \mathrm{~g}$ in $100 \mathrm{~mL}$

\section{Alkaline Preincubation Solution}

1. Remove alkaline stock solution from fridge and allow stock solution to reach room temperature.

2. Adjust $\mathrm{pH}$ of an appropriate volume $(50 \mathrm{~mL})$ of alkaline stock solution to 10.50 using $5 \mathrm{M} \mathrm{NaOH}$ (This should be done with continuous mixing and a $\mathrm{pH}$ meter sensitive to $0.001 \mathrm{pH}$ units).

\section{Acid Preincubation Solution}

1. Remove acid stock solution from fridge and allow stock solution to get to reach room temperature.

2. Adjust $\mathrm{pH}$ of an appropriate volume $(50 \mathrm{~mL})$ of acid stock solution to $4.30,4.54$, 4.60 with glacial acetic acid (This should be done with continuous mixing and a $\mathrm{pH}$ meter sensitive to $0.001 \mathrm{pH}$ units).

\section{ATP Preincubation Solution, pH 9.4 (PREPARE FRESH DAILY)}

1. Add $170 \mathrm{mg}$ of ATP (SIGMA A2383) to $100 \mathrm{~mL}$ volumetric flask and bring up to volume using ALKALINE STOCK SOLUTION.

2. Adjust $\mathrm{pH}$ to 9.4 .

3. Keep in fridge $\left(4^{\circ} \mathrm{C}\right)$ until ready for use.

\section{$1 \%$ Calcium Chloride Stock Solution}

1. Dissolve $10 \mathrm{~g}$ of $\mathrm{CaCl}_{2} \cdot \mathrm{H}_{2} \mathrm{O}$ in $1000 \mathrm{~mL}$ volumetric flask using MilliQ $\mathrm{H}_{2} \mathrm{O}$ and bring up to volume.

2. Store at room temperature.

$\underline{2 \% \text { Cobalt Chloride }}$

1. Dissolve $5 \mathrm{~g}$ of $\mathrm{CoCl}_{2} \cdot 6 \mathrm{H}_{2} \mathrm{O}$ in $250 \mathrm{~mL}$ volumetric flask using MilliQ $\mathrm{H}_{2} \mathrm{O}$ and bring up to volume.

2. Cover in aluminum foil and store at room temperature.

\section{$1 \%$ Ammonium Sulfide (PREPARE FRESH DAILY)}

1. Add $5 \mathrm{~mL}$ of $20 \%$ ammonium sulfide solution to $100 \mathrm{~mL}$ volumetric flask.

2. Bring to volume.

3. Store in fume hood until ready for use. 


\section{PART C: FIBRE TYPE STAINING PROCEDURE}

1. Incubate the sections in acid preincubation solutions adjusted to a pH of $4.30,4.54$ and 4.60; and alkaline preincubation solution adjusted to $\mathrm{pH}$ of 10.50 at the following time periods:

\begin{tabular}{|l|l|}
\hline $\mathrm{pH}$ & Incubation time (min) \\
\hline 10.50 & 25 \\
\hline 4.54 & 7.5 \\
\hline 4.60 & 7.0 \\
\hline 4.30 & 5.0 \\
\hline
\end{tabular}

2. Transfer slides into plastic staining trough.

3. Rinse slides in distilled water 3 times.

4. Incubate slides in ATP incubation solution for 45 minutes at $37^{\circ} \mathrm{C}$, in a temperature-controlled shaker.

5. Rinse slides in distilled water 2 times.

6. Incubate slides in $1 \% \mathrm{CaCl}_{2} \cdot 2 \mathrm{H}_{2} \mathrm{O}$ (Calcium Chloride) for 3 minutes at room temperature.

7. Rinse slides in distilled water 5 times.

8. Incubate slides in $2 \% \mathrm{CoCl}_{2} \cdot 6 \mathrm{H}_{2} \mathrm{O}$ (Cobalt Chloride) for 3 minutes at room temperature.

9. Rinse slides with distilled water 5 times.

10. Incubate slides in $1 \%$ ammonium sulphide for 1 minute at room temperature.

11. Rinse slides in distilled water 5 times.

12. Dehydrate tissue for 2 minutes in each alcohol concentrations $(70,80,90,95$ and $100 \%$ ethanol).

13. Clear sections with xylene. Do this twice in clean xylene @ 2 minutes.

14. Blot off excess xylene using Kimwipes. Mount the coverslips on slides using Permount (Fisher SP15-100). Allow Permount to dry $(\sim 1 \mathrm{~h})$. Store slides in the dark when not in use. 


\section{PART D: CAPTURING IMAGES / IMAGE ANALYSIS}

1. Turn on camera and microscope and allow to warm up for $5 \mathrm{~min}$.

2. Focus image at $4 x$ magnification.

3. Refocus image at $20 \mathrm{x}$ magnification to calculate fibre area $\left(\mu \mathrm{m}^{2}\right)$.

4. Open SPOT Advanced software.

5. Click "Get Image" icon to capture image.

6. Click "Focus" icon to refocus image.

7. Save image as .jpg file.

8. Capture 3-4 images per sample.

9. When finished with microscope and camera:

a. Remove slide, lower platform, turn off camera, then microscope.

b. Replace lens and dust covers.

10. Analyze Images using ImagePro Plus to determine fibre area $\left(\mu \mathrm{m}^{2}\right)$. 